\title{
Producing, Handling and Archiving Evidence in Mediterranean Societies
}

\author{
Camios fazen los omes unos con otros de que an meester cartas \\ ESPÉCULO, LEY XXXVI
}

Why is it that so few Islamic archives have survived, while Western ones did? Why is it that Ottoman societies have yielded archival collections dating back to the 16th century, whilst their immediate predecessors have not? Is there a reason why archives appear to be confined to the Ottoman era, and why they seem to have been absent under other dynasties? Did medieval Muslims rely on writing and documentation to engage in social competition and reproduction? If they did not, is this because they were less literate, less eager to engage in "impersonal exchange," or less prone to develop institutional participation? If orality was a dominant vector in Islamic society, sanctioned by law, how was it dealt with in practice, for example to keep track of legal, administrative or commercial transactions?

The story behind the whereabouts of Islamic legal and administrative collections is a troubled one, and debates about the lack of archives, often adopting conflicting methods and goals, attest to the different disciplines' fraught relationship with the Islamic past and its records. In this chapter, I analyze how these important issues have been approached in the past and are increasingly being discussed today. In their quest to discover a historiographical locus for the treasures of Islamic chanceries and tribunals, researchers have speculated on the nature of hoards found in Jerusalem, Damascus, Qayrawān, al-Quṣayr, the monastery of St. Catherine at Mount Sinai or in Old Cairo. Were these document collections archives? If so, it is argued, the debate should revolve not so much around differences in sophistication between Eastern and Western institutions, as around the more-or-less accidental causes of their non-survival. At a time in which the Islamic historical narrative, based on literature produced by the piety minded, has superseded the labor of social and economic history, research studies drawing upon Ottoman judiciary and government 
collections, in contrast, have long outnumbered cultural studies. This is all the more astonishing for a field, such as Islamic history, in which the bias towards the religious-minded, the ulama, and their sources, is so strong that it has led Roy Mottahedeh to label most Islamic social history as mere "ulamology."1 The great majority of contributions prefer to simply sidestep the issue by acknowledging the lack of archives for the medieval period and focusing instead on processes of document destruction, recycling or hoarding in unusual placesusually concluding with a call for a fresh appraisal of the surviving remains of medieval records.

I open my discussion on the handling of evidence by tackling the current debate on the non-survival of medieval Islamic records and their permanence in the West, the 'archival divide'; a debate that I argue is mostly based on typecast attitudes and assumptions about Islamic history. Yet it is all the more fruitful because it begs a discussion and a clarification of a series of misconceptions about practices, artifacts, legal institutions on Islamic law, trade and diplomacy - such as those that foreign merchants, diplomats and travelers had to deal with in everyday situations at the marketplace and in court. Thus, important as it is, the debate masks a much broader discussion, revolving around changes in notions of justice, proof and evidence that were becoming apparent towards the turn of the 16th century, in the context of a much more polarized Mediterranean, and for which commercial litigation constitutes a privileged vantage point.

I adopt the view that, by and large, for the medieval period all extant documents are loose items, and a critical mass of artifacts is reached only in the 14th century for the Islamic core regions of Syria, Iran and Anatolia. ${ }^{2}$ Document troves deposited in some mosques, together with the so-called Genizas and similar trash heaps have turned out to be miscellaneous aggregations rather than archives. Although he nuances the catastrophic vision of a medieval world bereft of archives, Konrad Hirschler, an important voice in this debate, states that there was only "a limited institutional logic of document preservation and that documents were discarded when they ceased to be of relevance for the individual." Indeed, for the period prior to 1517, most extant documents have only survived thanks to private collections and 'counter-archival' practices (such as recycling). More important for my argument is acknowledging the sudden wealth of documents represented by the maturation of the Ottoman Empire: or, in the words of R. Stephen Humphreys, "The 10th/16th century ...

\footnotetext{
1 Humphreys, R. Stephen: Islamic history: a framework for inquiry, Princeton, N.J.: Princeton University Press, 1991, 187.

2 Humphreys, Islamic history, 40.
} 
marks a revolution, for from this point on the vast resources of the Ottoman archives lie before us." Judicial archives have yielded collections for Cairo (1522), Alexandria, Damascus (1583), Hama (1536), Jerusalem and Aleppo (1547) starting as early as the 16th century, while Sarajevo, several locations in Albania, Bulgaria, Cyprus, followed by Macedonia, Salonika and Hungary start in the 17th century. ${ }^{3}$ The birth of the judicial (and to a great extent also administrative) archive was an Ottoman phenomenon, and accordingly is confined to the lands under the aegis of the Ottoman sultans. However soft the enforcement of Ottoman sovereignty in faraway regions, it is all the more meaningful that the trend towards archive preservation was absent in, say, competing early modern polities such as the Mughal Empire or Morocco. Moreover, the birth of the archive in this region marks a general change of attitude towards what constituted proof, from the signing of contracts to the taking of testimony and oaths.

In this first section, I guide the reader through the current debate on the existence or absence of Islamic medieval archives. The literature on the archival divide is extensive, and the discussion on writing and documentation has reached such a high degree of technicality that it would benefit from reappraisal in a more historical light. That is, by asking how artifacts were produced, by whom, and to what extent this production was subject to change over time. Focusing on Islamic archives, this discussion spans the medieval and early modern periods, and splits into several threads which, in order to be understood, require proficiency in areas of expertise such as comparative law, papyrology and archeology. The debate suffers from a marked division of labor between experts on Mamluk and Ottoman studies and their relative linguistic biases, thus making a diachronic appraisal of the issue, spanning both periods, more challenging. However, the need for one is all the more pressing when we consider that many authors do not appear to have taken account of the stark differences between the medieval sultanates and the Ottoman Empire, in terms of the relationship between the state and religion-something that ultimately affected the functioning of Islamic justice. Ottoman qadis were heavily involved in the administration of the provinces, and were also expected to apply regulations issued by the sultans on the grounds of public, customary law

3 Faroqhi, Suraiya: "Sidjill", Encyclopaedia of Islam, Second Edition, IX, 538-545, 1996, Fitzgerald, Timothy Jude: Ottoman methods of conquest: Legal imperialism and the city of Aleppo, 1480-1570, PhD dissertation, Harvard University, Vol. 3365261, Ann Arbor, 2009, 222-3. Fizgerald mentions that the earliest registers for Aleppo include a few late Mamluk documents. A good discussion on starting dates for the Arab countries is provided by Alsabagh, Munther H., Before Banks: Credit, Society, and Law in Sixteenth-Century Palestine and Syria, PhD dissertation, University of California, Santa Barbara, 2018, 38-9. 
(kanun). ${ }^{4}$ The need for them to refer to precedent, therefore, meant that their attitude towards archived documents differed greatly from that of medieval judges, whose principal task consisted in arbitrating private disputes according to the mostly oral procedure of sharīa.

Since all voices in the choir do not necessarily read from the same sheet music, I find it useful to identify three main axes within the discussion, all revolving around the production and use of proof in society. The first deals with justice, and includes works addressing the Ottoman legal reform and the role of legal proof in society. A second thread addresses the notion of textuality, discussing the changing uses of writing and documentation by the Islamic state. Lastly, a third group identifies major shifts in the production of written proof, or notarization, and its impact on the very "fabric of trust" in Mediterranean societies. My aim is to discuss what I define as historicist, or materialist approaches to the archival divide. A good deal of recent contributions, by attempting to unearth more artifacts in order to prove that larger collections did actually exist, have missed the opportunity to explain the divergent approaches to record preservation, and the very different meanings of proof in Latin and Islamicate societies.

Following this critical overview of the current discussion, I pay particular attention to several artifacts, spaces and institutions related to the presence of foreigners and their commercial disputes, and that will be crucial to the arguments advanced in subsequent chapters. With an emphasis on transformation over time, I tackle the issue of how judicial archives were passed on from one judge to another, the changes undergone by artifacts supporting written proof - such as scrolls and ledgers - and finally, proof-producing, scribal institutions at work in Middle Eastern markets. In the field of law, the production of proof had very direct and relevant consequences. For this reason, and following the views of authors such as Baber Johansen, I look at doctrines on proof and evidence that ultimately determined what responsibility the community had for its storage. I argue that medieval jurisprudence was crystal clear in defining the value of archived documents: after a judge had been dismissed from office, archived documents lost their value as proof, and jurists themselves describe the trimming procedure the successor qadi was expected to adopt. Concepts, but also tools and practices related to the production of evidence changed with Ottoman legal reform; words such as dīwān, formerly evoking the idea of court decisions, came to signify a physical place or an "archive", as did the term

4 Aykan, Yavuz: Rendre la justice à Amid: procedures, acteurs et doctrines dans le contexte ottoman du XVIIIème siècle, Leiden-Boston: Brill, 2016, 145, İnalcık, Halil: Suleiman the Lawgiver and Ottoman law: Mounton, 1969. 
sijill, which from "scroll" came to mean the notarized, codex-shaped collection of proceedings in a given courthouse.

In this chapter I aim to convey the dynamism behind these newly-adopted patterns in notarizing legal acts, to capture the changing roles of notaries and scribes, and the enhanced value that written texts had for the Ottomanswhat I define here as new attitudes towards the written word. A caveat needs to be advanced here, however: it would be tempting to think of this dynamism as a process of progressive modernization and rationalization, a natural tendency to enhance the written word and the archived document above orality and witnessing. ${ }^{5}$ However, as illustrated in the final chapters of this book, new attitudes towards written proof and documentation, which might be associated with modernity, coexisted with much more conservative ones-such as the return to a strict use of oral witnessing in many fields of governance. In the last section of the present chapter, I evoke, by way of example, the problems that could arise at the imperial Divvān due to a refusal to keep written proceedings. The Dīvān was an institution that combined governance and judicial functions, and was the focal point for legal relations with the Franks. The latter, however, were often puzzled by how little value the pashas gave to written records, and their insistence on the need for Muslim witnesses in order to accept agreements as valid. Mistrust for written records, therefore, did not completely disappear under the Ottomans. Reflecting on this apparent contradiction, Reem Meshal has described the "grafting" of witnessing onto the notarial deed, in an attempt to account for the Ottoman qadis' new role, which included notarizing and archiving what had traditionally been the lot of oral, private witnesses operating in streets and markets. She insists on a more harmonious vision of the relationship between jurisprudence-hostile to written artifacts - and a legal practice keen to use them. Yet despite its innovation, and a more open attitude towards records and archives, after 1517 the complex and sometimes contradictory handling of oral/written proof played out in peculiar ways, and began to pervade Muslim-Christian relations more than ever.

\subsection{The 'Archival Divide'}

The debate on the non-survival of Islamic archives dates back to early 2othcentury investigations into the social and economic history of the Mediterranean. The question of the existence or absence of sources was crucial to the

5 Aykan, Rendre la justice à Amid, 228-29. 
work of Jean Sauvaget who, in his tireless enthusiasm for unearthing Ottoman archives, contracted a severe illness that eventually led to his death in 1950, aged forty-nine. ${ }^{6}$ For Sauvaget, the non-survival of archives could be pinned on the egalitarian character of Islam, and the consequent lack of status groups that might have led to the birth of, for example, the seigniorial institutions and collections characteristic of the European trajectory. A second, legal explanation focused on the divine nature of the law and the fact that the sources of Islamic jurisprudence were rooted in the sunna of the Prophet and the Qur'ān - that is, outside the sphere of temporal powers ("la volonté du souverain ne suffit pas à créer le droit"). ${ }^{7}$ Together with these new contributions to the debate, Sauvaget was the first to advance the argument that will be developed here: that the prevalence of oral over written proof as legal evidence hindered the development of judicial archives. ${ }^{8}$

More than seventy years after the first edition of Sauvaget's book, in which he explained these theories, a solid piece of research on Mamluk documentary production appeared in 2016. In it, Konrad Hirschler addresses again the vexata quaestio of the absence of Islamic archives. ${ }^{9}$ Like many of his fellowresearchers, Hirschler returns to a hotly-debated passage written by Michael Chamberlain in 1994, where the latter addresses the issue by proposing a "social logic" to the absence of collections. According to Google Scholar, Chamberlain's book has been cited on no less than 344 occasions, and many point to this notorious passage on the lack of archives. For this reason, Chamberlain's text well deserves to be quoted here extensively:

Is accidental loss the reason that historians have so few original document collections from the high medieval Middle East? ... In the Latin West documents were unmistakable proofs of privilege, exemption, competence, precedent, honor, or possession. As nations, classes, corporations, religious bodies, families, status groups, and factions fought out their struggles with documents, they took measures to preserve them. This accounts in part for the survival of a large number of collections of original documents from high medieval Europe compared to the high medieval Middle East. The critical position of the document within

6 Robert, Louis, “Jean Sauvaget", Revue Historique 207 1 (1952), 173-184, Sauvaget, Jean, “Comment étudier l'histoire du monde arabe, 5", Revue Africaine 9o (1946), 5 .

7 Sauvaget, Jean: Introduction to the history of the Muslim East: a bibliographical guide. Berkeley: University of California Press, 1965.

8 Sauvaget, Introduction to the history of the Muslim East, 19-21.

9 Hirschler, "From Archive to Archival Practices". 
European social and political competition also shaped the development of modern European historiography. When European historians began to exploit original documents, it was often to examine such symbolic charters to subvert or assert inherited rights, autonomy, sovereignty, titles, and ownership. Collections of documents therefore survived in greater numbers not by accident, but because elite groups exerted themselves to preserve them. And the crucial role of documents in European historiography is in like manner grounded in European practices of social and political competition.

In the high medieval Middle East, however, rulers maintained patrimonial if not absolutist claims, considered most of the wealth of their subjects their own, and permitted other social bodies none of the formal autonomies they had in Europe. Individuals, households, religious bodies, and groups did not brandish documents as proofs of hereditary status, privilege, or property to the extent they did in the Latin West. Nor were their strategies of social reproduction recorded, sanctified, or fought out through documents to the extent they were in Europe. ${ }^{10}$

In his preface to Knowledge and Social Practice in Medieval Damascus, Chamberlain unpacks some of his more thought-provoking theses on archival absence. Aside from framing the problem in terms of social competition, he suggests that the alternate forum for social antagonism and perpetuation was not the archive, but the biographical dictionary, a genre that reached its maturity in the late Mamluk period (and in light of these works' comprehensive treatment of society, and the extensive recourse to them by researchers, it seems that a good deal of historians would agree). However, my intention here is not to discuss Sauvaget or Chamberlain's respective theses, even if the latter's analysis is noteworthy because it places the question of the absence of archives beyond the hazards of archaeology, stressing the lack of any defined logic of document safeguarding.

Many historical works attempt to capture the reader's interest by claiming the timeliness and relevance of their topic. It goes beyond mere rhetoric to say that not only in recent years, but even in recent months, attempts to account for the lack of pre-modern Islamic archives have been gaining momentum. Most of these recent works on missing archives attempt to nuance, counter and even mock Chamberlain's arguments on why collections have

10 Chamberlain, Michael: Knowledge and social practice in medieval Damascus, $1190-1350$, Cambridge; New York: Cambridge University Press, 1994, 13-4. 
not survived. As previously noted, however, Hirschler is alone in pointing to a narrow institutional logic for the preservation of records, that "were discarded when they ceased to be of relevance for the individual," although he claims that collections were nonetheless kept through alternative archival practices, different from the building of central state archives. Whether Chamberlain's Weberian polarization between a multi-layered and institutionalized Western society, and an egalitarian/patrimonial Islamic one is justified or not, the truth is that the prestige of the archival record and its weight in Western historiography constitutes a threat to the self-esteem of specialists of Islamic societies. Current reappraisals of the archival divide by Frédéric Bauden, Petra Sijpesteijn, Marina Rustow, Tamer El-Leithy or Hirschler himself are being carried out in parallel with research projects that target alternative archival practices inherent to documentary troves in Damascus, Cairo or miscellaneous Mamluk collections of reused documents. ${ }^{11}$

Although present-day historians are increasingly turning against the formal elements of Chamberlain's argument, they have less often criticized one crucial aspect of it: that what is missing is not so much the archive itself, as specific patterns of document preservation. Differences between Eastern and Western attitudes towards the production and preservation of documents did exist. But differences are visible, too, between the several Islamic powers, and these attitudes also changed over time. A privileged locus for such differences is commercial litigation, along with other forms of exchange, such as crossconfessional diplomacy - that is, by observing the work of agents such as consuls, pashas and chancery clerks. In these places, litigants and diplomatic actors often stumbled over differences in existing conceptions of proof. Rather than approaching the issue, either from a static binomial of two opposing systems, or from a flat paradigm where Islamic and Western trajectories were

11 Bauden, Frédéric: "Du destin des archives en Islam. Analyse des données et éléments de réponse", in: La correspondance entre souverains, princes et cités-États. Approches croisées entre l'Orient musulman, l'Occident latin et Byzance (XIIIe-début XVIe s.), edited by Denise Aigle: Turnhout, 2013, 9-30, Sijpesteijn, Petra M.: The Archival Mind In Early Islamic Egypt: Two Arabic Papyri, in: From al-Andalus to Khurasan: Documents from the Medieval Muslim World, edited by P. Sijpesteijn and L. Sundelin, 2007, 163-186, Rustow, Marina, "A petition to a woman at the Fatimid court (413-414a.h./1022-23 c.e.)", Bulletin of the School of Oriental and African Studies 73 or (2010), 1—27, Hirschler, "Document Reuse in Medieval Arabic Manuscripts", Humfress, Caroline: "Institutionalisation between Theory and Practice: Comparative Approaches to Medieval Islamic and Late Roman Law", in: Diverging paths?: the shapes of power and institutions in medieval Christendom and Islam, edited by John Hudson and Ana Rodríguez López, Leiden-Boston: Brill, 2014, 16-29, El-Leithy, Tamer, "Living Documents, Dying Archives: Towards a Historical Anthropology of Medieval Arabic Archives", al-Qantara 32 (2011), 389-434. 
equal, I argue that each actor's awareness of the other's peculiarities made them more careful in the handling and production of proof. These divergences in approaches to proof and evidence did not at all lessen in Ottoman times, and awareness of them affected the actions and discourses of Frankish consuls and representatives. The debate would have much to gain, therefore, from taking into account the divergent attitudes between Franks and Muslims, between medieval sultans and their Ottoman successors, and the different rationales behind judiciary and government/chancery archives.

As Reem Meshal puts it, legal practices were traditionally dictated by a trove of customary solutions that entered into conflict with Ottoman legal reform. Under the Ottomans, foreigners increasingly felt the need to procure themselves documents backed by qadis to secure their claims, and more generally, to conform to Islamic legal practice for their businesses. Moreover, in the 16th century a new archival locus emerged: the courthouse (mahkama) archive, a development that makes it all the more challenging to distinguish between Eastern and Western approaches to proof. To be sure, in the following pages it is not my intention to delve into the technicalities of how judges and officials certified, used and archived records - a task whose complexity has reached its peak in the analysis of the Haram al-Sharif documents found in Jerusalem in 1974 and 1976, and of which we will hear more. Instead, I proceed by stressing the comparative dimension of archive survival, and by carrying out a tour d'horizon of the relevant literature on the archival divide. My aim is to suggest that, by considering the history of Islamic societies to be fundamentally different from the labor of 'Occidentalists,' all too often researchers have been tempted to look for materialist explanations to justify the lack of Islamic archives. Instead, I argue that exploring different notions and ideas about proof and evidence can help us to understand this lack, and that commercial litigation -in its multiple configurations - can tell us much about the practical ways in which this archival divide was dealt with.

\subsubsection{A Threefold Problem}

Arguments that dwell on the longue durée of Islamic law and institutions, such as that advanced by Sauvaget, are long gone. Today, the debate revolves more around the extensive recourse that Islamic societies had to writing, as proof for the existence of archives. Paradoxically, and as a result of this apologetic tendency, the very question of why archives did not survive has been sidelined. The controversy about archives has given way to a parochial, increasingly technical discussion that might benefit from a more historical approach. In order to untangle the archival controversy, I identify three overlapping, yet distinct threads in the historical literature. 
a) Justice

The first strand of research concerns Islamic justice, and more specifically judicial practice. According to this line of enquiry, a dramatic shift changed the way in which Middle Eastern societies, non-Muslims and foreign merchants interacted with Islamic justice. This transformation is marked by the appearance of the courthouse-the mahkama-and its archives of court proceedings - the sicil - a process that crystalized in Ottoman lands over the course of the 16th century, including in the newly-conquered Arab provinces and even the Balkans, where similar phenomena have been noted. ${ }^{12}$ Reem Meshal has also stressed the standardization of judicial procedure, extending from Aleppo to Mecca; indeed, local law schools began to see their traditional dominance challenged by the now superior authority of the hanafi judges. ${ }^{13}$ In the Arab lands under the aegis of the Mamluks, people chose different courts depending on the nature of the transaction, as some schools had different attitudes towards, say, marriage or debt contracts. ${ }^{14}$ Under the Ottomans, qadis were public notaries with ample prerogative for registering most kinds of contracts. Therefore early modern Muslims' daily interactions were now generally framed by a valid legal documentary framework - mostly in the form of notarial deeds, or hujjas — and by more consistent access to justice guaranteed by the qadi's court, now enshrined in a permanent institution whose records could be consulted and used to build precedent.

The judicial ledgers included, together with court proceedings, the deeds drawn up by the qadis as notaries, reflecting the different kinds of contractual relationships within society. ${ }^{15}$ Reem Meshal has found a remarkable statement in a ḥanafĩ fatwā that epitomizes these new attitudes to legal practice: "the sijill is a hujja", or in other words, "this register is a de facto hujja", meaning that Ottoman court proceedings, beyond their mere role of physically preserving judicial decisions, provided legal coverage for people's actions, rights, and

12 Peirce, Leslie P.: Morality tales: law and gender in the Ottoman court of Aintab, Berkeley: University Of California Press, 2003, Meshal, Sharia and the Making of the Modern Egyptian, Al-Qattan, Najwa, "Dhimmis in the Muslim Court: Legal Autonomy and Religious Discrimination”, International Journal of Middle East Studies 313 (1999), 429-44, Canbakal, Hülya: Society and politics in an Ottoman town: Ayntab in the 17th century, Leiden; Boston: Brill, 2007.

13 Meshal, Reem A, The State, the Community and the Individual; Local Custom and the Construction of Orthodoxy in the Sijills of Ottoman-Cairo, 1558-1646, PhD dissertation, Institute of Islamic Studies, McGill University, 2006, 115, Aykan, Rendre la justice à Amid, 227-23o.

14 Rapoport, "Legal Diversity in the Age of Taqlid".

15 Aykan, Rendre la justice à Amid, 228. 
agreements. Hujjas were issued on all legal matters by Ottoman qadis, meant, if needed, to be used elsewhere and not only at the mahkama where it was produced. Hujjas concluded with the formula: "What happened was written down and delivered to the applicant, so that he may produce it as proof whenever there is need". ${ }^{16}$ The recourse to judges to notarize legal deeds provided right holders with permanent legal coverage, not just for recovering debts, but any situation that could potentially be subject to dispute, such as being a freed former slave or a divorced woman. ${ }^{17}$ These actions, undertaken either in or out of court, could be recognized as valid by virtue of the court's capacity to notarize and archive the deeds once and for all. The sijill was a hujja for-since most notarized deeds were now kept in the qadi's ledgers- right holders, including European merchants, could now turn to these repositories to validate their rights and claims, and not only in the event of a trial. ${ }^{18}$ This was in contrast with the medieval practice whereby, although the notary delivered a copy to the right holder, the client needed to summon both the notary and his witnesses in court in order to give oral testimony of the transaction.

\section{b) Textuality}

A second line of inquiry deals with the Islamic state, and the tendency towards textuality exhibited by the Ottoman style of governance; defined by Guy Burak as the "calligraphic language of power that supplemented the shared vocabulary of sovereignty." Brinkley Morris Messick has looked at how the authority of scholars, traditions and oral witnessing in traditional Yemen was replaced by the authority of texts, ranging from university diplomas to legal and administrative regulations. A series of contributions by Burak very forcefully demonstrate new attitudes towards texts that took shape under Ottoman governance. Needless to say, the birth not only of the judicial archive, but also of state central registers contributed much to this new expression of sovereignty and governance. Burak argues, however, that not only archived documents were endowed with the charisma of governance; records such as judicial deeds were accompanied by a wide array of texts, ranging from chronicles to jurisprudence. ${ }^{19}$ These researchers have provided a fresh interpretation of

16 Imber, Colin: Ebu's-su'ud: the Islamic legal tradition, Edinburgh: Edinburgh University Press, 1997, 52-3, Ottoman hanafi jurists started to include the delivering of hujjas among the current duties of the qadis, Ibn Nujaym, Zayn al-Dīn Ibn Ibrāhīm (1520-63): al-Ashbāh wa-al-naz̄āir 'alá madhhab Abì Hanīfah al-Nu'mān, Damascus: Dar al-Fikr, 2005, 293.

17 Gradeva, Rossitsa, "Orthodox Christians in the Kadi Courts: The Practice of the Sofia Sheriat Court, Seventeenth Century", Islamic Law and Society 41 (1997), 37-69.

18 Ergene, Boğaç, "Document Use in Ottoman Courts of Law”, Turcica 37 (2005), 83-111.

19 Burak, "Evidentiary truth claims", Burak, "In Compliance with the Old Register", 8oo. 
the changing attitudes towards legal documents-and writing and documentation more generally. For Meshal, textuality made a more impersonal rule possible, and spurred the transition from subject to citizen. For Burak, on the other hand, in the early Ottoman period textuality encouraged both the rulers and the ruled, Muslims and non-Muslims, to increasingly put their trust in documentary artifacts; incorporated into their daily routines it ultimately altered power relationships at all levels of society, in the family and between communities. To Meshal, textuality was used as a motor for social change, whilst Burak considers all nature of texts to have been part and parcel of the Ottoman approach to statecraft and sovereignty. ${ }^{20}$ Ottoman governance, not as a polity, but as a discourse, was anchored in a "spectrum of writings and associated institutions," such as archives. ${ }^{21}$

Unfortunately, debates revolving around governance, textuality and state archives often turn into a discussion about the state of medieval Islamic archives. In recent years, scholarship has often adopted a lachrymose, apologetic view of Islamic history, and partly as a result of Western misconceptions about the non-preservation of documents and the lack of archives, it has been victim to Western methodologies and research agendas. Papyrologists, experts in diplomacy and Geniza studies, among others, have touted the popular argument that a virtual archive does exist, but that we historians simply have not realized it yet. And indeed, these authors have been successful in unearthing more or less significant collections of documentary artifacts, whose richness they equate with the archival traditions of medieval Europe. Apart from being overly politically correct, this line of reasoning exhibits some major pitfalls; to mention just one, it still remains to be seen if there is any clear relationship between the production and use of the documents found in these troves, and the existence of any actual logic of preservation. As the epicenter of medieval Islam, and the motherland of scribal culture, land and tax registers and papyrology, it is the fate of Egypt's medieval administrative legacy that has been the most anxiously debated. Although in the past the issue has attracted the interest of social and economic historians, the debate has been largely monopolized by specialists in Islamic documents. At the time of writing this chapter, several research projects were underway to enlarge the trove of medieval Islamic documentary collections, and the idea that these archives have simply not survived, rather than never been kept at all, is gaining an alarming amount of momentum. Most contributions point to the fact that Islamic societies were

\footnotetext{
20 Meshal, Sharia and the Making of the Modern Egyptian, 11-12.

21 Messick, Brinkley Morris: The Calligraphic State: Textual Domination and History in a Muslim Society, Berkeley: University of California Press, 1993, 252-257.
} 
highly literate, and acquainted with the use and production of documents. Other voices, however, suggest shifting the focus away from the quest for archival loci such as state archives, and looking instead to the Islamic "archival mind," to "archival practices," "archivalities" and more interestingly and as regards preservation, to "documentary life-cycles" and the reuse of documents. While historians such as Wael B. Hallaq, Frédéric Bauden, Petra Sijpesteijn, Marina Rustow, Maaike Van Berkel or Tamer el-Leithy insist that everyone in Islamic societies, from judges to widows and dhimmis, had their part to play in the proliferation of documents, the fundamental question as to why these documents were not the object of any long-standing logic of preservation remains essentially unanswered. This is mainly because these contributions have failed to distinguish between production and use, on the one hand, and preservation, on the other.

In recent years, authors have claimed that proof for the archival tradition can be found in the diplomas preserved in the private archives of their recipients, such as the collection of medieval government decrees at Saint Catherine's of Sinai. The corpus of decrees preserved at the monastery give examples of medieval mazālim practice, or policy-based regulations issued by the reigning sultans, together with decisions made as a result of a legal complaint. ${ }^{22}$ The Cairo Geniza hosts Fatimid decrees and petitions, and includes a ruling issued to a woman that has been used by Rustow and El-Leithy as proof of an alleged Islamic tradition of archiving petitions. A more popular argument, however, is that secretaries and judges did in fact use and store drafts and copies of original deeds in the exercise of their functions. However, descriptions of such practices point more to temporary storage than to true archiving, and when copies were made, more often than not the motivation for it greatly differed from archival processes. Diplomatic artifacts, for instance, have survived in encyclopedias or vade mecums, leading Bauden and others to claim that copying a chancery document in a handbook served in itself the purposes of archiving. ${ }^{23}$

Maaike Van Berkel's work on the Abbasids similarly fails in its purpose to vindicate an early Islamic archival culture, showing, nonetheless, interesting instances of document use and temporary storage by Abbasid clerks, as

22 Nielsen, Jørgen S.:SecularJustice in an Islamic State:Mazālim under the BaḥīMamlūks, 662/ 1264-789/1387, Leiden: Nederlands Historisch-Archaeologisch Instituut te Istanbul, 1985.

23 In this regard, an interesting discussion on literacy and the use of documentary evidence can be found in Robinson, Chase F.: Islamic historiography, Cambridge-New York: Cambridge University Press, 2003, 145-7. To Robinson these practices were widespread in Islamic historiography, yet they cannot be equated with archival practices. 
epitomized in the description of vizier 'Alī Ibn 'Īsā's chaotic trove of records. Other known practices were the copying of correspondences, the record keeping of agricultural revenue and taxation and those associated with petition justice (dīwān al-mazālim). It has been noted that the Abbasid empire was grounded on a powerful administration, recruiting empire-wide and assuring centralized taxation. In the late Abbasid period, the caliphate eventually yielded to a new, decentralized administrative culture, organized around the idea of the autonomous management of fiefs $\left(\right.$ iqtă $\left.^{-}\right)$and taxation, at the service of a nomadic-minded military. While equating scattered, provincial troves with a proper archival culture, Van Berkel admits a dramatic lack of information on the locales (actual repositories, and physical places) for these practices, the patrimonial notions whereby documents were considered personal property of secretaries, most notably of the viziers, and the dislocation of collections vis-à-vis the political powers, distant from the Caliphal headquarters. A more sophisticated archival culture associated with the Abbasid caliphate-and caliphates in general, vis-à-vis the sultanian model of governance remains a suggestive hypothesis, yet more research efforts will be needed in order to prove it. ${ }^{24}$

The temporary storage of documents to facilitate the drafting of records was, as descriptions of the late Mamluk chancery have made clear, a different practice from the archiving of state papers, and it seldom led to the actual preservation of collections. The survival of records in unexpected places most often implies that a document was not preserved due to the positive value of the information it contained, but to its role as a specimen. This is clearly the case for chancery compendia and manuals of legal formularies, often invoked as meta-archives-such as those of al-Qalqashandī (1355-1418) or Ibn Hijjah al-Ḥamāwì (d.1434). ${ }^{25}$ To be sure, since the Neolithic no sophisticated polity in the old world has ever managed to survive without attaining a certain degree of sophistication in the production and storage of information; however, the kind of archival practices described by Mamluk secretaries such as al-Qalqashandī can hardly be adduced as proof for the existence of archives. Although it is true that chancery manuals describe the drafting of documents such as petitions, and their storage for future reference, these descriptions present clerks keeping their documents in the back office or in their personal collections at best.

24 Van Berkel, Maaike: "Reconstructing Archival Practices in Abbasid Baghdad", Journal of Abbasid Studies, 1, 1 2014: 7-22.

25 Ibn Hijjah al-Hamawī, Taqī al-Dīn Abū Bakr Ibn 'Alī (d.1434): Qahwat al-Inshä', edited by Rudolf Veselý, Beirut: Klaus Schwarz Verlag, 2005. 
The mid fifteenth-century text by Shams al-Dīn Muhammad al-Saḥmāwī is probably the only authoritative text that deals in some detail with late Mamluk archival practices. These practices are presented as being strictly connected to the drafting of documents, together with others such as the procedure for sealing, using and storing pens. The "archive," or rather, the Dīwān's annex (muta'alliq al-dīwān), al-Saḥmāwì goes on, should be close to the scribes' workshop, and much stress is placed on procedures for controlling access to the chancery and preventing fraud by scribes, particularly in the form of interpolations and other unlawful additions to the register, or daftar. The recordkeeping procedure puts emphasis on linking entries in the current daftar to a single clerk. This annex guards not only blank decrees but also those already signed by the sultan, such as answers to petitions and other records returned from the palace back to the Chancery. In it is preserved a particular pouch, the muzarrah, which appears to have been crucial to late Mamluk chancery practices and linked to the early archival artifacts used by judges (such as the qimațr and qimațr-like practices described below). Al-Saḥmāwī was therefore less concerned with preservation than with storage, and gave details on how to guard against the damages of excessive ventilation, humidity or mice. ${ }^{26}$

The terminology used by al-Saḥmāwī to describe the dīwān and its staff differs from that in use in Fatimid times, a period for which authors have allegedly found evidence of more consistent archival practices. Indeed, the description of the Fatimid chancery by Ibn al-Ṣayrafì (1071-1147) has attracted a good deal of attention, since it mentions storage procedures, as well as the presence of a clerk (khāzin) charged with archiving and drafting inventories for official correspondence. ${ }^{27}$ Meïr Max Bravmann has also optimistically conjectured the existence of a site dedicated to the storage of archives under the Orthodox Caliph 'Uthmān (644-656), based on references to a place called the Bayt al-Qarāțīs (House of Documents) by early authors such as al-Balādhurī and al-Ṭabarī. ${ }^{28}$ By the same token, allusions to similar procedures and collections can be found

26 al-Saḥmāwī, Shams al-Dīn Muḥammad (d. 868/1464): al-Thaghr al-bāsim fi șinā́at al-kātib wa-al-kātim: al-ma'rūf bi-ism al-Maqșad al-rafí al-manshā al-hādī li-dīwān al-inshā lilKhālidī, edited by Ashraf Muhammad Anas and Ḥusayn Nașșār, 2 vol, Cairo: Mațba'at Dār al-Kutub wa-al-Wathā’iq al-Qawmīyah bi-al-Qāhirah, 20o9, 372-374.

27 Ibn al-Ṣayrafī, 'Alī Ibn Munjib (1071-1147): al-Qānūn fì dīwān al-rasā'il, edited by Ayman Fu’ād Sayyid, Cairo: al-Dār al-Miṣrīyah al-Lubnānīyah, 1990 34-41. al-Qalqashandī, Aḥmad Ibn 'Alī (1355 or 6-1418): Șubḥ al-a ša fì Kitābāat al-inšā, 14 vol, Cairo: 1914, 1913 I 133, 135-6. el-Shayyal, Gamal el-Din: "Ibn al-Sayrafi", in: Encyclopaedia of Islam, Second Edition, III: 932a.

28 Bravmann, M. M.: “The State Archives In The Early Islamic Era”, in: The spiritual background of early Islam: studies in ancient Arab concepts 311-314. Leiden; Boston: Brill, 2009. 
for the Abbasid Caliphate. ${ }^{29}$ Interestingly enough, Bravmann has contested the views of Claude Cahen, who in several of his works has addressed the murky status of the written documents and archives characteristic of the late medieval sultanates, as we shall see in the next section. However, the late medieval authors of chancery handbooks often cited in support of the existence of archives, such as al-Qalqashandī, were well aware that in their own time it was no longer standard practice to draft inventories and file originals (and this is an issue to which I will return). ${ }^{30}$ However promising it may seem, the hypothesis of an early archival tradition in Islamic lands would require further empirical evidence, and wherever this tradition did exist, it hardly found continuity after the fall of the Fatimid Caliphate.

To return to late Mamluk practices, the muzarrah, or silken bag covering the government decrees for their safe-keeping, is not mentioned by alQalqashandī-who, incidentally, does not refer to the sijill as a scroll. While al-Qalqashandī and previous authors repeat the mantra that scribes should keep track (shāhid) of their documentary production, this point seems to be less relevant for al-Sahmāwī, who places much more emphasis on guarding the daftar against manipulation. The daftar described by al-Sahmāwī id not contain actual copies of the documents issued by the Chancery, but only brief summaries (mulakhkhas), and nothing is said about a policy to collect these daftars over time. $.^{31} \mathrm{Al}-\mathrm{Sah} m \overline{\mathrm{a}} \mathrm{i} \overline{\mathrm{l}}$, moreover, clearly states that documents did not leave the chancery to join larger state collections, and served only as reference documents for the chancery staff.

The muzarrah is linked to the peculiar spatial layout of Medieval governance, a point of crucial importance to which I will return: blank decrees needed to be protected in its way from the chancery premises to the citadel (ilā al-qașr), the center of military power where they would receive the sultan's signature ('alāma). The muzarrah aimed at grouping together all the different kinds of decrees and records needing subscription that were previously sent to the Citadel for signature one by one, or in small numbers, 'throughout the whole day' (fì țūl al-nahār). It is described as a folded piece of silken cloth, with a bag-like receptacle inside and a closing cord on one of its ends. Rather than a sophisticated archival artifact, the muzarrah appears as the center of a ceremony of document transportation presided over by the dawādār kātib al-sirr,

29 Delsalle, Paul: Une histoire de l'archivistique, Sainte-Foy, 1998, 48, Van Berkel, "Reconstructing Archival Practices in Abbasid Baghdad".

30 al-Qalqashandī, Șuḅ̣ al-a ša fi Kitābāt al-inšā, I, 139, al-Saḥmāwī, al-Thaghr al-bāsim, I, 375 .

31 al-Saḥmāwī, al-Thaghr al-bāsim, I, 373-4. 
an attorney of the Head of the Chancery, and entrusted to a hāmil al-muzarrah, or porter, a Mamluk clerk responsible for the integrity of the documents inside the pouch. ${ }^{32}$

One telling admission of a lack of archival references can be found in alSahmāwī's discussion on how to address the different sovereigns; in his digression on India he makes it clear that, if an archive existed at all, clerks in the Mamluk chancery clearly had no access to it. Six Indian polities (mamlaka) are mentioned. First, Delhi, "second only to Cairo among the cities of Islam", whose dynastic politics depend both on investiture by the Timurids and by the Abbasid Caliph in Cairo. The sultanate is followed by Cambay (Kanbāya), a well-known trading partner of the Mamluks in Gujarat, described as a large territorial power. The third mamlaka is Bengal (Bankālā), under the rule of Jalaluddin Muhammad Shah, and Sahmāwī mentions a letter sent to the Mamluk sultan Barsbāy in $840 \mathrm{OH} / 1436 .{ }^{33}$ Gulbarga (kālbarkā) is mentioned in fourth place, certainly due to the momentum attained by bilateral relations in the 15th century, with the foundation of the Ghulbarghiyya madrasa in Mecca and an embassy dispatched by the Bahmanid Sultan Aḥmad Shāh in 1427. Two less distinct polities close this outline of Indian geography: Șanbūb, ruled today by a certain sultan Ibrāhīm and, lastly, Mā Dūkn, a name that probably refers to Mandugarh, capital of the Sultanate of Mālwā. This last polity, represented by a large city lying "at the foot of the mountain" had a king bearing a Muslim name, Mahmūd (or Sultan Mahmūd Khaljī, 1436-69), although in diplomatic letters al-Sahmāwī advised that he be addressed in the same fashion "as the other kings of unbelievers." ${ }^{34}$ What is striking in this brief description is the absence of the Mamluks' principal partner, Calicut, and of polities that had sent embassies in the past and that should have been known to the chancery, such as Ceylon - at least, they are not referred to by the usual Arabic placenames (Sīlān). More importantly for our discussion, al-Saḥmāwī admits that, since no letter had been dispatched to Cambay in his own time (fì zamāninā),

32 The muzarrah is a late Ayyubid innovation, introduced by the qadi and vizier Tāj al-Dīn 'Abd al-Wahāb Ibn Bint al-A'az, al-Saḥmāwī, al-Thaghr al-bāsim, I, 375 .

33 Behrens-Abouseif, Doris: Practising Diplomacy in the Mamluk Sultanate: Gifts and Material Culture in the Medieval Islamic World, London and New York: IB Tauris, 2014, 46.

34 I owe the identification of Saḥmāwī's placename of Mā Dūkn with Mālwā to Prof. Sanjay Subrahmanyam, who considers the inclusion of the inland sultanate as sign of the completeness of Sahmāwī's description of the Indian subcontinent. Mālwā's direct contacts with the Mamluks are attested for 1467 , with an official exchange of letters, Meloy, John L.: "Mecca Entangled" in: The Mamluk Sultanate from the Perspective of Regional and World History, edited by Reuven Amitai and Stephan Conermann, Vandenhoeck \& Ruprecht; 2019, 453-79, 470-1. 
he could not provide specific instructions on how to address its ruler in diplomatic correspondence. This admission is important in that it points to a lack of continuity between the documents held during his tenure, and that of his predecessor; or in other words, the absence of archives extending beyond a single period of office.

In light of Sahmāwì's admissions, it is no wonder that those who advocate the existence of medieval archives have neglected this important text in favor of other sources, such al-Qalqashandī, of an accumulative nature and insensitive to change, and that often refer to the chancery in Fatimid times. Al-Saḥmāwi presents the daftar an individual decrees as highly sensitive documents, at risk of being manipulated for the issuance of fake rulings, as began to happen under 16th-century Ottoman administration, when scribes organized a forgery network on the basis of reused decrees. Indeed, as I will develop in the following section, al-Qalqashandī admits that such archiving practices were discontinued by Mamluk secretaries. Even more intriguingly, he also reports that the very practice of keeping a daftar tracking the chancery's activities was abandoned for years under sultan al-Zāaihir Barqūq (1382-1389 and 1390-1399) and his son al-Malik al-Nāșir Faraj (1405-1412). In the best-case scenario, these practices suggest that preservation was limited to the span of a single generation, and can hardly support the claim that medieval Muslims did not lag behind the West in the field of archival and record preservation. They did, but this does not have to imply any cultural superiority, if we remember to adopt the necessary cultural relativism.

At a time in which the apologetic genre is gaining momentum, I find it necessary to turn instead to a major work that has gone almost unnoticed: Nicolas Michel's essay entitled "The Circassians had burned the registers." In it, Michel focuses on the history of the Medieval archives of Egypt and their gradual disappearance by the time of the Ottoman conquest. ${ }^{35}$ Like Hirschler, Michel broaches the question of the register's materiality, but this he considers a secondary issue, as he judges the disappearance of Egypt's archives to be a historical, rather than a contingent phenomenon linked to the way records were handled. He addresses the waning of medieval administrative practices, not by looking to material explanations for the disappearance of paper, but by framing archival practices within the context of processes of Ottomanization, and the new masters' recourse to textuality as the basis for new models of governance. He also looks at the microhistory of the Mamluk administration, and 
the role played by individual secretaries in the potential transmission—or lack thereof - of Egypt's tax and land registers from Mamluk to Ottoman hands. Late-Ottoman clerks explained to the French colonists that the Mamluk archives had been burnt by Egyptian secretaries to prevent them falling into Ottoman hands; however, if the available chronicle material is anything to go by, it seems clear that the medieval Mamluks never saw the possession of archives as an attribute of sovereignty in the first place. Mamluk archives were kept 'downtown' in the secretaries' houses, and the very idea of keeping archives in the citadel — the epicenter of military power — was only an Ottoman innovation. ${ }^{36}$ More importantly, while papyrologists still look to the hazards of document destruction to explain the lack of archives, from a historian's perspective this explanation can be found in the fact that the Ottomans, wherever necessary, incorporated the contents of registers and the skill of Mamluk secretaries into the newly-founded administration.

As an important footnote to Michel's work, Wakako Kumakura has recently shed new light on the incorporation of secretarial dynasties into the new administration. ${ }^{37}$ In brief, Michel explains that towards 155 o the Ottomans came to the realization that their own cadastral survey, completed in 1528 , and upon which the Ottoman taxation system depended, was not trustworthy. After the conquest, the Ottomans set about taking measurements of agricultural land, and to a large extent the survey was informed by depositions by local witnesses and notaries. Due mostly to the latter's intervention in the drafting of the cadaster, tax exemptions and other privileges had proliferated, and were impossible to ascertain on the basis of the 1528 registers. In order to make sense of the old, cryptic Mamluk surveys, and identify the true status of estates prior to 1517 , which were now claimed as exempted, the Ottoman rulers also had recourse to Mamluk clerks from the Ibn al-Jīān and al-Malakī families, who had been monopolizing secretarial functions under the charge of the mustawfi dīwān al-jaysh, the official in charge of the army's accounts. Paradoxically enough, considering their disdain for the previous administrative regime, the Ottomans also issued a decree stipulating that in case of conflict, priority would be given to the old, Mamluk records. Former Mamluk secretaries took great pains to collect the old registers, and coordinated the transfer of the data they contained to the Ottoman tax administration. In the process, the original registers themselves were not preserved, as there had been no logic of record

36 Ibid. 234-5, 254 .

37 Kumakura, Wakako, "Who Handed over Mamluk Land Registers to the Ottomans? A Study on the Administrators of Land Records in the Late Mamluk Period", Mamluk Studies Review XVIII (2015), 279-298. 
preservation from previous dynasties to protect them, and they did not comply with Ottoman standards on authorship and authoritativeness. By virtue of this process, Mamluk scribal knowledge was grafted into the Ottoman archival mind.

The anonymous, unpublished manuscript Orientale 98, from the National library in Rome, neatly embodies the subsequent stage in this process of transition between two styles of administrative governance. The manuscript contains five texts concerned with the governance and administration of Egypt. The first is an anonymous treatise entitled Kitāb al-qawānīn al-sulțāniyya wa-l-fawāid al-dīwāniyya ("Rules of Government and Notes on the Dīwān"). ${ }^{38}$ This neglected work, most likely produced in the late 158 os, is flanked by two well-known texts: the Kanunname-i Mısır and the Kitäb al-tuhfah al-sanìyah biasmā’ al-bilād al-mişrīyah by Sharaf al-Dīn Ibn al-Jī̄ān (d.148o), as well as two lesser-known, shorter treatises. One is a Mamluk introduction to the combined use of the Coptic, solar calendar and the Arab one, based on the lunar cycles for administrative purposes, while the other is a brief work on weights and measures. The Kitāb al-Qawānin deals with the handling of a variety of state affairs by administrators, in the broad sense of the term, and therefore pays a great deal of attention not only to civil secretaries, but to the administrative role of the Ottoman qadis. It shares some of the same characteristics as a chancery manual, since it deals with the issuing of edicts and court rulings by military and judicial administrators, however it departs from inshä' literature in that it does not provide potential apprentices with actual formularies. Rather than provide templates of decrees and letters verbatim, the author gives some context for each case, together with the document's most relevant sections. The Kitāb al-Qawānin was something of a legal treatise in Siyāsa, dwelling on the lawfulness of some administrative practices, taxes and rights associated with the privy council of the sultan.

The Kitāb al-Qawānin is accompanied by the Ottoman corpus of regulations issued by Süleyman for Egypt in 1525 (the Kanunname), together with the highlight of Mamluk civil administration, the Tuhfah, a long, updated version of a 14th-century cadastral survey of Egypt. In gross, the Tuhfah is an exhaustive list of agricultural fiefs subjected to taxation, the land-based financial system upon which the Mamluk military institution was based, known as the iqțāc system. The text allowed Mamluk clerks to monitor the attribution of fiefs (iqtāāât) between the time of al-Ashraf Sha'bān (1363-1377) and the late fifteenth century. As a compendium, the Orientale 98 manuscript seeks to illustrate the handover 
of Egypt's administration to her new rulers after 1517, dwelling on the many problematic aspects that might be of interest for trainee secretaries. As for the Kitāb al-Qawānin, the compendium's only original work, it covers a wide range of topics, including some unexpected ones, such as how to deal with exotic birds. The work's major interest, however, are the miscellaneous aspects of the sultan's finances, such as the ruler's interests in Mecca, fluvial shipping over the Euphrates, taxes on silk imports or the revenues raised from the Khān alKhalili market in Cairo. The author even provides the reader with some valuable figures on topics extending from sugar production to the amounts of spices Egypt provides to the Imperial kitchen in Istanbul.

Often adopting the language of the legally learned, the author of the Kitāb al-Qawānin endeavors, in the first instance, to make a clear distinction between what it identifies as old Mamluk practices ('āda qadìma), and the fairer Ottoman ones. At several points in the text, the author presents a more rational and fair fiscal treatment of Indian and hajj ships arriving mostly at al-Tor in the Sinai peninsula, but also at al-Qusayr and Suez. Discussing a decree issued in $968 \mathrm{H} / 1560$, the author claims that the Ottoman administration, contrary to "old practice," taxed pilgrims from Mecca only with half the tithe ('ushr), while under the Mamluks a full two-thirds was collected. ${ }^{39}$ Similarly, the legal onetenth was levied on Indian spices, while previous illicit taxes had now been abolished. The Ottomans, it was thus argued, conformed to sharī'a in matters of taxation. To enforce this policy, the regulations were registered "in the sijills and in the Dīwān's daftars." Copies of this decision (hukm) were issued, delivered into the hands of three merchants, Khawājā Sāliḥ, Khawājā Ibn al-Jamāl and Khawājā Ibn Tu'ayma. The new fiscal regime is presented not as having been introduced at the initiative of the ruler, but as the result of intercession by a local qadi; an explanation that thus grounds the decision's motives in sharía. Together with the sultan's finances, the work turns much of its attention to the handling of agricultural revenue by the Egyptian administration, focusing on the issues of measuring, registering and collecting revenue for the land plots that used to constitute the Mamluk fiefs. The author deals extensively with the issuing of executive decrees (marsūms) and judicial rulings (hukm, arḍ), and how they ought to be filed and archived in daftars and sijills, as well as the procedure for delivering copies as an integral part of Ottoman governance.

The Kitāb al-Qawānin differs from similar Mamluk-era treatises in that it does not clearly differentiate between the judiciary and the chancery spheres. Similarly, al-Qalqashandī and al-Saḥmāwī seldom mention the terms sijill 
(pl. sijillāt), and when they do they refer to documents issued in the context of diplomatic exchange. Al-Qalqashandī includes some sections on agricultural taxes, or kharāj, and also uses sijill to mean registration documents for land plots (sijillāt al-taḥ̣īr), a use that can also be found in the Kitāb al-Qawāninn. None of these texts, however, describes the sijill as a major byproduct of the qadi's functions, and for the case of al-Qalqashandì it is unclear whether the author even understands sijill as an artifact taking the shape of a scroll. In none of these works do secretaries appear to handle court rulings and proceedings as part of their daily activities. For the two most authoritative Mamluk authors on the subject, then, work in the chancery had almost no connection with the judiciary.

In the Kitāb al-Qawānin, the term sijill refers to a variety of records produced by the qadis, who acted as administrators. Furthermore, references to a double registration in both the sijill and the daftar present decisions as pertaining to both the judicial and executive spheres. ${ }^{40}$ Incidentally, Mamluk treatises never refer very clearly to actual archiving and to the issuing of copies. The work they describe is instead presented as a succession of șuras, or copies of documents issued by civil authorities. Indeed, when comparing Mamluk and Ottoman inshä' literature, we realize that in the latter period the use of judicial records extended to ample areas of governance and administration. The Kitāb al-Qawänin refers, for example, to the importance of the sijills in the governance of the Red Sea. The 'ushr regime was imposed on Indian ships hailing from "known places" duly registered in a sijill, implying that unidentified foreigners were subjected to different forms of taxation. ${ }^{41}$ There exists, therefore, a sijill containing the names of the countries covered by amān or similar legal devices. The practice of drafting notarial deeds is a manifestation of Ottoman governance: tax bureaus (qalams) were in the habit of levying a number of illicit taxes, on paper, bread, highway use and many other activities. The Ottoman system reduced these taxes to five types, two of which are related, all the more significantly, to the drafting of registered testimonies (shahāda) and sijills. ${ }^{42}$

A second feature of the Kitāb al-Qawānin is that it adopts a specifically Ottoman attitude that censured Mamluk, and more broadly pre-Ottoman customary legal practice. As I argue in this book, the traditional notarial framework was not abolished, but was considered insufficient, and much attention was paid to the registration of acknowledgements, decisions and notarial deeds,

\footnotetext{
40 BNCR, Ms. Orientali $98,15 \mathrm{~V}, 19 \mathrm{v}$.

41 BNCR, Ms. Orientali 98, $5 \mathrm{v}$.

42 BNCR, Ms. Orientali 98, 11 .
} 
both in administrative inventories and judicial registers. The author addresses the problems that could arise when a Muslim produced a witness' certificate (shahāda) without further supporting evidence, or literally, "carries a shahāda in his hands" (bi-anna fulān bi-yadihi shahāda nawāhīi kadha wa innahu mustaqim). He reports a ruling by a local judge, who argued that if the rightholder was an honest man, and recognized as such by his peers, traditional practices should be respected and the shahāda accepted, and that there was no injustice in it because such decisions respected the general right of trustworthy Muslims to give testimony for facts. In response to the judge's ruling, an executive order was issued, warning local magistrates and clerks not to accept any witnesses that did not enjoy a formal appointment (taqrīr). ${ }^{43}$ According to Ibn Iyās (1448-ca. 1524), Ottoman policies regarding witnesses sought to limit their number and to control their activities. From the outset, under Ottoman rule only registered notaries were allowed to act in the Șâlihiyya madrasa, where the chief hanafí justice held court. ${ }^{44}$ Ibn Iyās mentions the imprisonment of Shams al-Dīn Muḥammad al-Munāwī, a ḥanafĩ deputy judge, for bearing witness outside the Șâlihiyya in a dispute over debt. ${ }^{45}$ For the Kitāb al-Qawāninn, customary notions of truth-bearing were upheld, however stress was now placed on its control by the state-appointed judiciary.

Under the Ottomans then, according to the Kitāb al-Qawānin, the notarial activities carried out by the 'udūl ought mostly to be confined to the rural countryside. In these areas, the judge relied mainly on inspectors (kāshifs, umanā) and notary-witnesses (shāhids) to draw up all manner of deeds and to bear witness to facts. The estimation of crops for tax purposes and other fiscal issues are one of the text's principal concerns, because oppression (zulm) and bad governance often stemmed from a judge's poor management of his own notaries and inspectors. These clerks should to be appointed "by virtue of their religiosity, ethical behavior and knowledge." Notaries and assistant judges needed to be monitored, and should only act in the judge's knowledge, and under his authorization. The Ottoman rotation in tenure is well known; judges were often unhappy with the places they had been assigned to, and could resort to appointing "worthless deputies [nāibs] with no concern for the local community," leading the court's shuhūd to begin "embezzling the people's

43 BNCR, Ms. Orientali 98, 12v.

44 Ibn Iyās, Muḥammad Ibn Aḥmad (1448-ca.1524): Badā’’ al-Zuhūr fì Waqā̉i al-Duhūr, edited by Muḥammad Mușțafá, 5 vol, Wiesbaden: Franz Steiner Verlag, 1960-1975, v, $165^{-6}, 466$.

45 Baldwin, James E.: Islamic Law and Empire in Ottoman Cairo: Edinburgh University Press, 2017,86 . 
properties unjustly, and embroiling every legal business that comes into their hands, so that they take what they want from it ... and they just start issuing hujjas and registering notifications (sijillāt)." Clearly, for the Kitāb's author, notarization played a crucial role in the governance of Egypt's rural areas. According to Ottoman Kanun, it was up to the villagers of local communities (qariā) to appoint reputable shāhids, failing which registers (sijillāt) rife with untruths could proliferate. ${ }^{46}$

The Kitāb reports that in many places instructions were given for the assignment, registration and taxation of land plots. On occasion, inspectors were required to produce legal notifications (sijill shar $\bar{i}$ ) to be filed in the notaries' daftar. ${ }^{47}$ The author alludes here to the fact that, at least in cases of notarial deeds for which taxes had to be levied, such as marriage deeds, Ottoman notaries did keep registers, hence departing from medieval practice. A good deal of attention is thus paid to the fees required for registering deeds at the courthouse (mahkama). Disputes over land plots were often arbitrated on the basis of information contained in the "dīwān's daftars." The judge was advised not to content himself with the mere acknowledgement and summoning of witnesses (išhād) but to verify the contents, accompany its drafting and eventual registration in the inventories or daftars. ${ }^{48}$

The administrative technicalities in the Kitāb al-Qawānin all point to a new approach to the written proof by the Egyptian administration, and indeed more examples could be unearthed in this text. Written a few decades after the collapse of the Mamluk state, it echoes the crisis, identified by Michel, that Ottoman governance was undergoing in the 155 os. The administrative practice it describes reflects the new limits now being set for traditional notarization, the sudden proliferation of registering activities, and the enhanced role of qadis as administrators, all expressed in a new language of governance.

c) Notarization

The third thread in the historical literature that can help us more clearly understand the archival divide revolves around the idea of notarization. Latemedieval, post-caliphate societies, and in particular polities ruled by sultanssuch as the Mamluk state - witnessed the rise of the notarial profession. Under the Mamluks, the recourse to 'udūl transcended the traditional notarial framework to which it had previously been limited — that is, as witnesses to private

\footnotetext{
46 BNCR, Ms. Orientali 98, 16r-v.

47 BNCR, Ms. Orientali 98, $19 \mathrm{v}$.

48 BNCR, Ms. Orientali 98, 12r, 19v.
} 
transactions - and was extended to multiple aspects of administration. ${ }^{49}$ As was the case for Latin Europe, notarial clerks were attached to many administrations, and in their daily activities Frankish merchants dealt with several categories of scribes, including Muslim 'udūl, in places such as the customs house and the port in Alexandria. ${ }^{50}$ The Franks invariably distinguished between testimoni (witnesses) and common scribes, hence underlining the importance placed on sight and hearing over writing. It seems that most Mamluk administrative departments, such as the Khizāna, ${ }^{51}$ the Bayt al-Māl and the Citadel ${ }^{52}$ relied on their own notarial staff. This proliferation of 'udūl in the administration responded to the need to guarantee the validity of legal acts, such as transactions and sales contracts notarized at the customs house. Their very presence in these departments could only have been a hindrance to the development of these administrations' archives, since transactions were guaranteed by the traditional reliance on eyewitnesses. Orality had its limits, however, and we have indirect evidence that, when working for these administrations, records were systematically kept by the clerks. In the following section I discuss a Frankish inquiry conducted in Alexandria in 1387, in which it emerges that no clear distinction could be drawn between the notarial clerk's own records and the archives proper to each bureau. These administrations' records were not placed in an institutional repository, but rather kept by the 'udūl who notarized them as personal archives.

Mamluk 'udūl enjoyed the capacity of certifiers of truth, and did so on a local, neighborhood basis. Mamluk chronicles depict the 'udūl's activities as embedded in the daily life of markets, mosques and neighborhoods. Particularly in Syria, mentions of the 'udūl and their workplaces (mahallāt, marākiz, often located near the city gates) give the impression that there existed a market for truth-bearing that was specific to a given territory, each one controlled by its

49 "the function of the notary was traditionally private, i.e. commissioned outside of court and performed in the name of the notary rather than the judge", Meshal, "The State, the Community and the Individual", 118. Veselý, Rudolf, "Die Hauptprobleme der Diplomatik arabischer Privaturkurden aus dem spätmittelalterlichen Ägypten”, Archiv Orientali XL 40 (1972), 312-43, 324.

Ibn Taghrībirdī, Abū al-Maḥāsin Yūsuf (1411-1470): al-Nujūm al-Zāhirah fì Mulūk Miṣr waal-Qāhirah, edited by Muḥammad Ḥusayn Shams al-Dīn, Beirut: Dār al-Kutub al-'Ilmīyah, 1992, VII, 313 .

51 al-'Aynī, Badr al-Dīn Maḥmūd Ibn Aḥmad (1361-1451): Iqd al-jumān fì tārīkh ahl alzamān: 'aṣr salāțīn al-Mamālīk, edited by Muhammad Muhammad Amīn, Cairo: alHay’ah al-Miṣrīyah al-'̄Ammmah lil-Kitāb, 1987, III, 29, Ibn Taghrībirdī, al-Nujūm al-Zāhirah, $\mathrm{X}, 217$. al-'Aynī, Iqd al-jumān fì tārīkh ahl al-zamān: 'așr salāțīn al-Mamālīk, III, 32, 173, 175-6. 
respective team of 'udūl. ${ }^{33}$ Even if we should not make generalizations based on criticisms against corrupt 'udūl, one has to acknowledge that notaries were linked to sources of power such as qadi courts and emir households, and belonged to socially dominant families. ${ }^{54}$ These criticisms do however abound, pointing to the fact that very often notarial services were used for illegitimate purposes throughout Mamluk society. The fact that it was not the written notarial deed, but the notary and his assistants' testimony itself that ultimately mattered, was a formidable source of power, and in part at the service of Mamluk governance. For this reason, Ottoman rule aimed to control the 'udūl, as well as to dismiss large branches of the notarial profession as a major step in the judicial reform program, an important point raised by Meshal. Other authors such as Najwa Al-Qattan and Hülya Canbakal have noted that Ottoman reform, which enhanced the notarial functions of judges, rendered the medieval 'udūl obsolete outside of Egypt. ${ }^{55}$ Not surprisingly, they counted among the first victims of the Ottoman legal reforms, and some were even deported to Istanbul shortly after the occupation. ${ }^{56}$ Considered to be corrupt, large-scale dismissals by Ottoman reformers began in 1517 , and then again in 1520 . The frequency with which they seem to have been reappointed is however some indication of how crucial the notarial institution was to Egyptian society, and more broadly, of the divergent interests of central and local judiciaries. ${ }^{57}$

The influential work of Ronald C. Jennings further elaborates on the new role of notaries in the Ottoman era by addressing the functions of the shuhüd $a l-h a \bar{a} l$ in the 17th-century Ottoman city of Kayseri, and argues that a closed milieu of medieval 'udūl—exerting a monopoly over truth-bearing — transformed into to an opener system in Ottoman times. Jennings shifted the focus to the shuhūd el-hạl, the 'instrumental witnesses,' or trustworthy Muslims attached to the courthouse who, rather than notarizing acts themselves, monitored the notarial and judicial functions of the qadi, hence acting to curb the latter's

53 Mandaville, Jon Elliot: The Muslim Judiciary of Damascus in the Late Mamluk Period, Princeton University, Ph.D., 1969, 9-10, 121-2, Ḥamzah, 'Ādil 'Abd al-Ḥāfiz: Niyābat Halabfi 'Așr Salāțin al-Mamālīk (1250-1517 M/648-923 H). Vol. 2: al-Hay’ah al-Mișrīyah al-Āmmah lil-Kitāb, 200o, 254-5.

54 Kosei, Morimoto, "What Ibn Khaldun Saw: The Judiciary of Mamluk Egypt", Mamluk Studies Review 6 (2002), 109-131, 112.

55 Canbakal, Society and politics in an Ottoman town: 'Ayntab in the 17th century, 129-30, AlQattan, "Dhimmis in the Muslim Court: Legal Autonomy and Religious Discrimination".

56 Ibn Iyās, Badä̉ic al-Zuhūr, V, 178-9.

57 Meshal, "The State, the Community and the Individual", 121, Meshal, "Antagonistic Shari`as", 183, 199-200, Meshal, Sharia and the Making of the Modern Egyptian, 89-93, Michel: "Les Circassiens avaient brûlé les registres", 253. 
power. ${ }^{58}$ Historians of Ottoman law generally agree that these 'court' witnesses ought to be distinguished from notary-witnesses — that is, the 'udūl drawing up deeds in the markets and other public places. Although the actual functions of the shuhüd el-hăl differed from one city to another, their general role was to attest to the validity of court proceedings, and sometimes to carry out scribal functions at court. While mentions to the 'udūl are rare after 1500, instrumental witnesses were central to Ottoman legal procedure. They were appointed by judges, and seem to have received some kind of legal training. ${ }^{59}$

Together with the notary's status, the object that they were most often solicited to produce, the hujja, underwent similar changes. Changes in the use, production and preservation of the hujja were closely tied to the spread of the mahkama/sijill binomial in Ottoman society. While formally the legal definition and value of the hujja remained the same, it is the way in which it was used in society that was radically different. It is difficult to know the extent to which the notarized deeds produced by scribes in their stalls continued to circulate as the fundamental probative artifact in Muslim societies, and if so, they certainly were accompanied by an increasing number of notarized artifacts generated by Ottoman judges. ${ }^{60}$ The Ottomans empowered the hanafi judges over all other notarial actors, put them in charge of notarizing the most important contracts, and made it compulsory to register certain agreements before them. Thus, if the Ottoman takeover was bad news for the Arab notaries that staffed administrative departments, even the 'udūl working in the markets had their functions as bearers of truth increasingly curtailed by the judge-sanctioned hujja. Indeed, the very oral essence of medieval notarization had made it unnecessary to preserve records. In medieval notarial practice,

$5^{8}$ Jennings, R., "Kadi, court, and legal procedure in 17th C. Ottoman Kayseri", Studia Islamica 48 (1978), 133, Imber, Colin The Ottoman Empire, 1300-1650: The Structure of Power: Palgrave, 2002, 233 .

59 Baldwin, Islamic Law and Empire in Ottoman Cairo, 36-7. Müller, Christian: "Ecrire pour établir Ia preuve orale en Islam: la pratique d'un tribunal à Jérusalem au XIVe siècle", in: Les outils de la pensée: Etude historique et comparative des textes, edited by Akira Saito and Yusuke Nakamura, 63-99: Editions de la Maison des sciences de I'homme, 2010, 75, Müller, Christian: "The Power of the Pen: Cadis and their Archives in Medieval Islam", in: Manuscripts and Archives: Comparative Views on Record-Keeping, edited by Alessandro Bausi, 361-385: Walter de Gruyter, 2018, 374-5, Sonbol, Amira, "Women in Sharíah courts: a historical and methodological discussion", Fordham International Law Journal 271 (2003), 225-253, 243.

6o 'Alī Ibrāhīm Mīlād, Salwā, "Registres judiciaires du tribunal de la Salihiyya NagmiyyaEtude des archives", Annales Islamologiques 12 (1974), 161, 182-88, provides a detailed description of how documents notarized at a law court, such as property deeds, were eventually produced by the parties as the basis for new transactions. 
the trustworthiness of a given document resided in the capacity of two original witnesses to verify it. After the death of these witnesses, the record's validity, if it had any at all, was always contested. With the qadi's enhanced role as an agent of Ottoman governance, together with his activities as a regular notary, the medieval 'qadi archive,' soon became obsolete. Despite efforts by senior scholars such as Wael B. Hallaq to prove that a medieval archival tradition existed, these works have been more successful in unveiling the technicalities used by medieval judges to cope with the fragile status of paper, than to prove any continuity with early modern practice. ${ }^{61}$ Before Ottoman times, there was absolutely no logic of long-term preservation for judicial records. Rather, we know that only a few sensitive documents survived when a new judge took up his functions, and that the qadi was not expected to rely on the papers produced by his predecessor. In gross, the medieval 'qadi archive' comprised a series of documents whose validity was kept alive by the judge, who validated them through the complex procedure of isjāl. Baber Johansen has written of the "ephemeral archive" and the peculiar rules for its transmission, based on his research on handbooks for qadis. Hallaq's views on the continuity between the medieval qadi archive and Ottoman practice have certainly been challenged from the perspective of court procedure, scrutinized by Müller in several studies of the Ḥaram al-Sharif's papers. ${ }^{62}$

Amalia Zomeño has devoted many efforts to analyze the role of writing and documentation in Spain's Islamic communities on the eve of the conquest. In fifteenth-century Granada notarial deeds were subjected to the same evidentiary rules as everywhere else in the Islamic world, so that "if a Muslim was challenged on the use of a piece of land that he considered to be his property, he had to go to court with his sale contract and show it to the judge. However, the judge himself would only accept the facts narrated in this contract if the professional witnesses, who wrote the deed, confirmed in his presence that the signatures in the document were theirs." ${ }^{33}$ Therefore it is no surprise if no

61 Hallaq, Wael B., "The qādì's dīwān (sijill) before the Ottomans", BSOAS 61 (1998), 415-436.

62 Johansen, Baber, "Formes de langage et fonctions publiques: Stéreotypes, témoins et offices dans la preuve par l'écrit en droit musulman", Arabica 443 (1997), 333-376, Müller, Christian, "The Ḥaram al-Sharîf collection of Arabic legal documents in Jerusalem: a Mamlūk court archive?", al-Qantara XXXII 2 (2011), 435-459, Burak, "Evidentiary truth claims",235, 252, Unlike Müller, the work of Burak has challenged Hallaq's conclusions not by studying the materiality of records but from the viewpoint of the role played by texts in Ottoman governance.

63 Carro, Sergio and Amalia Zomeño: "Identifying the 'udūl in Fifteenth-Century Granada", in: Legal Documents as Sources for the History of Muslim Societies: Studies in Honour of Rudolph Peters, Edited by Léon Buskens and Petra M. Sijpesteijn, 109-129. Leiden; Boston: Brill, 2017, Zomeño, Amalia, "From Private Collections to Archives; How Christians 
significant collections of judicial records have survived for the centuries prior to the conquest. In the mudéjar period (1492-1500), when Muslims were still tolerated, and willing to prove and transfer property as quickly as possible, they started brandishing notarial deeds issued according to Islamic law. Yet only after the decrees of expulsion were enacted Islamic records started to be translated, quoted and archived no longer in private collections, but by Christian institutions. Members of the new society deemed those records useful to sanction their newly acquired properties and status. Records were incorporated to court proceedings "according to the uses of the Muslims" and validated by converts. Arabic notarial deeds were advanced as proof in lawsuits over property opposing two Christian parties at a much later date. Paradoxically enough, it was only as a result of the Christian conquest that a significant trove of Arab documents have been preserved.

In this book, I refer to the medieval practice of record-keeping as the 'qimaț archive.' The qimaț was the transportable wooden box containing time-sensitive records that were considered worth preserving, and that early judges used to carry with them. In medieval times, the practice adopted by judges upon assuming their functions in a given locality was to re-certify a selection of records that might be needed in the future and, at least under the early caliphate, these documents were deposited and carried in the qimațr, as sessions were itinerant. The artifact adopted different forms over time, such as bags, and these ephemeral archives-mobile qimatr-archives - together with the trimmings of deeds drawn up under previous qadis, changed under the Ottomans. If only a minority of authors attribute the invention of the judicial archive tout court to the Ottomans, most specialists agree that they at least provided the qadi's papers with a stable locale.

Beyond the causality behind this historical watershed and the debate it sets off, one thing is for certain: with their approach to keeping registers (sicils), and the status of legal proof attached to them, the Ottomans brought with them major changes in the way Islamic societies handled writing and documentation. In a nutshell, Ottoman judges and secretaries were pressured to provide continuity for their practice. In the case of judges, the revolution came in the shape of a register, and the transformation of what until then

Kept Arabic Legal Documents in Granada", Al-Qantara: Revista de Estudios Arabes 322 (2011), 461-479, Zomeño, Amalia: "Notaries and Their Formulas: The Legacies from the University Library of Granada". dans From al-Andalus to Khurasan. Documents from the Medieval Islamic World, edited by P. Sijpesteijn and L. Sundelin, Leiden-Boston: E. J. Brill, 2007, 59-8o. 
had been scattered records - or, at best, scrolls comprising a series of appendixes collated to an original chart-into bound sets of legal documents. The legal innovation at the basis of the ledger was that the whole documentary trove pertaining to a single lawsuit - that is, anything that transited through the qadi's hands - was now entered into the sicil, or ledger, along with court proceedings, and was therefore certified by the judge. In medieval practice, witnesses would have been summoned to renew the deed's validity, a practice that was now abandoned as long as notarized documents included in the sicil did not require further validation. Under the Ottomans, all judicial papers included in the sicil had permanent validity, and were sewn together in a codex that was itself the object of archival procedure. Starting from the sixteenth century, Cairo registers were completed with a closing sheet and archived in the Dìvān's court for further reference, since copies of their contents could be delivered upon request. ${ }^{64}$ As for the hujja, the basic unit of the legal system in and out of court, research conducted on the basis of judicial archives is now showing that everyone in society, and lower-rank individuals more forcefully, now had at their disposal a tool to claim, keep and protect their rights from violation.

The major transformation experienced by notarization in the sixteenth century was intimately tied to changes introduced in the administration of justice on the one hand, and on the other, to a new tendency towards textuality in Ottoman governance. New patterns of notarization, the rise of judicial sicilkeeping, and the tendency for Ottoman governance to rely on authoritative texts were all part of the same phenomenon, and all had an impact, albeit unequally, on the way ordinary people dealt with writing and documentation. While medieval 'udūl saw virtue in keeping mustā’mins and women away from their workshops, scholars remark an unprecedented rise in women, foreigners and other excluded categories gaining access to the legal system. ${ }^{65}$ Taken together, these three threads constitute a fil rouge straddling the periods and topics covered by this research. After this survey of the historical literature, I will return in the next section to the narrative on Islamic archives between medieval and early modern times.

64 'Alī Ibrāhīm Mīlād, "Registres judiciaires du tribunal de la Salihiyya Nagmiyya—Etude des archives", 18 o.

65 Meshal, Sharia and the Making of the Modern Egyptian, 133-8, Peirce, Morality tales: law and gender in the Ottoman court of Aintab, 389, Sonbol, "Women in Shariah courts", Gradeva, "Orthodox Christians in the Kadi Courts", discusses access to justice by dhimmīs and their approach to evidence. 


\subsubsection{Materialist Explanations}

Since the twentieth century, explanations for the limited development of legally organized professional and corporate bodies have alternated with more materialist views. To the arguments advanced by Sauvaget, Claude Cahen (1909-1991) added political turmoil, or the hazards of the Ottoman takeover of the Medieval Arab administration. Together with these motives, he suggested that Islamic judicial systems were characterized by a rapid rotation in appointments, and that Islamic foundations had no legal personality, which implied that documents - such as waqf documents - were kept by qadis and authorities, hence hampering the development of institutional archives. Elaborating on a well-known theory according to which medieval Islam did not develop corporations, Samuel M. Stern suggested that the dearth of surviving archives was rooted in certain features of Islamic institutions, such as the lack of stable professional bodies. ${ }^{66}$ Despite this, for the early modern period-when such guilds actually came into being-Ottomanists have turned instead to judicial and government collections when dealing with artisan organizations. ${ }^{67}$

A good deal of recent literature, often critical of Chamberlain's thesis, have shifted the focus entirely away from record-keeping and preservation, and turned instead to the issue of whether documents were produced or not, used or not, and if they have survived in sufficient numbers. Launched in 2011, this approach to the debate is best epitomized by an article by Tamer El-Leithy, for whom Chamberlain's thesis, that "documents don't survive," is a "a totalizing argument" that "forecloses the space for any historical investigation of the social uses of medieval documents." El-Leithy goes on to claim that "legal documents were routinely produced by notaries and courts; they were assiduoushy preserved by individuals and families, who later consulted and brandished these written forms of evidence in disputes and conflicts." 68 Thus late medieval Islam,

66 Cahen, Claude: "Y a-t-il eu des corporations professionnelles dans le monde musulman classique? quelques notes et réflexions", in: The Islamic City, edited by S. M. Stern and A. Hourani, 51-63. Oxford, 1970, Cahen, Claude: "Du Moyen Âge aux Temps modernes", in: Les Arabes par leurs archives: XVIe-XXe siècles, Colloques internationaux du Centre national de la recherche scientifique $n$. 555, edited by Jacques Berque and Dominique Chevallier, 9-15. Paris: CNRs, 1976, Cahen, Claude: "Considérations sur l'utilisation des ouvrages de Droit musulman par l'historien", in: Les peuples musulmans dans l'histoire médiévale, 71-76. Cairo: Presses de l'Ifpo, 2014, Stern, S.M.: Fātimid Decrees: Original Documents from the Fātimid Chancery, London: Faber and Faber, 1964.

67 Faroqhi, Suraiya: Artisans of Empire: Crafts and Craftspeople Under the Ottomans, London and New York: I. B. Tauris, 2011, xix-xx.

68 El-Leithy, "Living Documents, Dying Archives", Rustow, "A petition to a woman at the Fatimid court". 
as epitomized by the Mamluk sultanate, witnessed the rise of sophisticated and literate societies, which naturally engendered archival institutions. To be sure, some authors have pushed the issue even further than El-Leithy, reducing it to a mere question of miscalculation. For Frédéric Bauden-papyrologist, diplomatist and expert on al-Maqrīzī - the very existence of documents for the medieval period proves that Islamic societies never lagged behind the West in the consumption and safe-keeping of records; it is simply that we have not yet realized the extent to which documents have been preserved. Indeed, Bauden brandishes papyruses and other surviving artifacts as rebuttals of Chamberlain's thesis, and the "calamitous" assumption that the Islamic premodern archive never existed. ${ }^{69}$ In the same vein, in a subsequent text Bauden counters Chamberlain's argument that Islamic societies were less prone to record preservation by claiming that secretaries were advised to keep personal copies of some charts. ${ }^{70}$ This particular line of reasoning is based on a vexing passage by al-Qalqashandì describing scribal practices at the Mamluk chancery, in which he reminds the clerks to keep trace (shāhid) of the documents they have drawn up. Bauden similarly challenges Chase F. Robinson's view that Arab societies placed more importance on historiography, and therefore on biography and prosopography, than on the preservation of records; a point that responds to Chamberlain's idea that it was the biographical dictionary that Muslim societies vested with an archival role. ${ }^{71}$

Bauden addresses three main arguments in the existing literature; that we should look further afield than state archives, that Islamic society had a skeptical attitude towards written artifacts, and that Islamic judicial records received a specific treatment. ${ }^{72}$ Bauden seems to accept that there was an

69 Bauden, F., "Mamluk Era Documentary Studies: The State of the Art", Mamluk Studies Review 9 (2005), 15-6o, 16., Bauden: "Du destin des archives en Islam", 31-33.

70 This argument is based on a passage by al-Qalqashandī, Subḥ al-aśsha fí Kitābāt al-inshā, VI, 198.

71 Robinson, Islamic historiography, 146. 66-79, 187-89.

72 "One of the most repeated [explanations] is that, unlike what happened in Europe, Islam had no legally organized social bodies which could have preserved archives, the unique exception being the waqf documents, as shown by Carl Petry. This means that only state archives could exist. Secondly, it has been argued that written documents do not establish the law (kitābun yushbih kitāban: one writing looks like another writing and can be exchanged with it), but if so why would non-Muslim communities have held for centuries documents that had no legal value and that were referred to in case of necessity? Thirdly, it has been alleged that in Europe most of the documents are of a judicial nature, while in Islam, on the other hand, these kinds of documents were kept by the qadis. When they became useless or obsolete, they were discarded", Bauden, "Mamluk Era Documentary Studies: The State of the Art", 17 . 
absence of professional and religious bodies that might have produced archives, and seems aware that, as we shall see, Islamic judges were not expected to preserve their records after they left office. Similarly, the Islamic suspicion for the written word (kitābun yushbih kitäban) has been noted; however, Bauden echoes a popular argument used to support the existence of the Islamic medieval archive, when he asks whether the preservation of documents in monasteries and by other recipients contradicts these views. Unfortunately, he misses the opportunity to reflect on why issuing authorities did not preserve decrees, while their non-Muslim addressees did. Unlike the trove of factual, materialist explanations for the non-existence of archives, these arguments are phrased in an elusive manner and do not receive sufficiently thorough treatment.

A second attempt to defend the existence of the Islamic medieval archive came in 2013, when Bauden took a firmer stance against the theses of Chamberlain and Chase F. Robinson. Countering Chamberlain's "naïve" idea that Islamic societies had a more limited recourse to documents, Bauden refers extensively to the drafting of circumstantial copies, the reuse of documents, temporary storage, and archive destruction, to support the idea that collections did exist, but that due to ideological motivations they were either neglected or simply destroyed - the presumed destruction by Saladin of the Fatimid archives being one such example. However, according to a recent reappraisal of this idea by Fozia Bora, the destruction by new Islamic rulers of their predecessors' archives and libraries has become an Orientalist, often unfounded, historical commonplace. ${ }^{73}$ All too often, in Islamic diplomatics voices have spoken out against positions like Chamberlain's, claiming that they are making arguments from silence. Yet the mere existence of fragmentary groups of documents or collections in unexpected places can hardly account for the intentionality of preservation.

Although Chamberlain acknowledges that tax and land records were kept, and decrees issued, his thesis holds that state, corporate, and household documents held little power in social competition interactions. For example, he argues that commercial contracts were considered to be separate from the political sphere, and that the nature of political relations was fundamentally non-contractual. Engin D. Akarlı's analysis of legal relations in the marketplace quotes a legal case brought to the imperial council in 1814, stressing this fundamental difference with old régime European societies. On that occasion,

73 Bauden: "Du destin des archives en Islam", 35, a view contested by Bora, Fozia, "Did Șalāḥ al-Dīn Destroy the Fatimids' Books? An Historiographical Enquiry", Journal of the Royal Asiatic Society 251 (2015), 21-39. 
Sultan Mahmud II argued that his decisions, after consultation with legal experts, were legally binding, irrespective of the existence of previous rulings on the same matter. In response to a legal dispute among three different groups of cloth dyers, the sultan had issued a decree that levelled customary statutory distinctions between different dyers and raised the rents they paid to a waqf. Some refused to accept the sultan's decision, claiming precedence for old legal records that confirmed their former rights. The sultan reprimanded them, asking "What does it mean to act in defiance of my decree? ... Destroy the documents in their hands and issue them new ones ... If any of the dyers dares to resist let me know! The new order will surely hold, once a few of them are hanged!"74 To return to Chamberlain's argument, Islamic societies are characterized as lacking in hereditary status; precedent was therefore far less relevant both to sharīa and in administrative practice. In response, Bauden cannot help but "smile" at the "naïve" idea that Islamic societies were less "drowned in paperwork" than their Western counterparts, and responds to the Chamberlain dilemma by reminding us that, whenever paper presented some value to the state, it was far more valuable for junk dealers. Although his argument that document reuse may have hindered the preservation of Islamic archives might well be worthy of consideration - provided it was supported with some documentary evidence-what is more difficult to accept is the claim by Bauden and others that reused documents stand as proof in themselves of the existence of archives. ${ }^{75}$

Occam's razor would have it that materialist explanations cannot be discarded merely because they are simpler, and therefore less satisfactory to intellectual taste. In the current debate, factual claims appear to suffice to counter the social and political constituents behind the lack of archives. This kind of reasoning frees authors from the need to substantiate their claims from an empirical standpoint, and allows them to speculate that archives always existed, and even enjoyed continuity across dynasties, even if they may have suffered the hazards of episodic destruction. It is useful here to return to the passage by Nicolas Michel mentioned above, which contradicts the more detailed historical work on this issue. One of the holes in Bauden's argument is his claim that something similar to a diplomatic Fatimid archive had existed, but that it did not find continuity in successive dynasties; however, he does not provide much evidence, either for its existence or destruction, beyond mere hypothesis.

\footnotetext{
74 Akarl, Engin Deniz: "Law in the Marketplace: Istanbul, 1730-1840", in: Dispensing Justice in Islam: Qadis and Their Judgments, edited by Muhammad Khalid Masud, Rudolph Peters, and David S. Powers, 245-70. Leiden: Brill, 2006, 264-5. 
According to Bauden "Le déménagement des archives fatimides, qui devaient être conservées dans les ministères situés à proximité des palais califaux, dans leur nouvel emplacement, la citadelle construite par Saladin, a dû constituer de ce point de vue un moment particulièrement destructeur". Such uncorroborated assumptions about the transfer of the collection to the new center of power, the citadel, can only further contribute to building a house of cards. Fatimid archives did exist, and they were kept close to the seat of power as a symbolic attribute of governance. And when Saladin modeled himself as a post-caliphate, sultanian — and therefore military—ruler, he did take the records with him up to the castle. However, where papyrologists simply content themselves with the assumption that the empirical evidence for is out there somewhere — and the documents do, after all, exist—it takes painstaking historical work to demonstrate the existence, or lack thereof, of all and every one of the elements in Bauden's hasty assumptions. Michel turns his attention to the jargon used by Mamluk secretaries when referring to where, and by whom, records were kept, and convincingly demonstrates that Mamluk records were held "downtown" in the secretaries' houses, and moved up not by Saladin, but by the Ottomans about four hundred years later. Records were first and foremost left in the hands of high-ranking secretaries, as the documents were not considered to represent either a form, or a manifestation of the sultan's governance. ${ }^{76}$ As we have seen, the muzarrah, an Ayyubid innovation, served the purposes of transporting decrees back and forth from the scribal workshops and the Citadel.

In the same fashion, Marina Rustow combines two of the arguments advanced so far in the debate on the archival divide: that many papyri have survived, and that written artifacts were used in many aspects of daily life in the medieval Middle East. It is worth noting that in her case study of a Fatimid petition from a woman, found in the Cairo Geniza collection, she concludes that the petition was probably preserved not so much as positive information, as to provide a model for future applications. This is an important point, as one might argue that many of the documents put forward by researchers to demonstrate that archives did exist were actually preserved to serve as models

76 "In addition to the records of the chancery, the wazir of the 'Abbasids kept copies of the most important documents in an archives office of his own.", Posner, Ernst, "Archives in Medieval Islam", The American Archivist 35 3-4 (1972), 291-316, 297, an argument confirmed by Van Berkel, "Reconstructing Archival Practices in Abbasid Baghdad", 13-4, Messick, The Calligraphic State, referring to the 1950s: adds that "The handling of administrative registers, which were always retained at home as the personal effects of officials or secretaries, also changed", 247. Hirschler, "From Archive to Archival Practices", 18-9. 
and formularies for clerks and scribes, hence implying a very different logic behind such practices:

In fact, the evidence of pre-Ottoman archives and archival practices is abundant, but it is also hardly investigated. Comparing the tens of thousands of surviving original Arabic papyri with early medieval Latin documents copied into cartularies suggests that the shopworn comparison with medieval Europe requires some rethinking. Frédéric Bauden has rightly called the notion that few documents have survived from the medieval Near East "calamitous," and made every effort to correct it for the Mamluk period in particular ${ }^{77}[\ldots]$ Writing and documentation, in short, pervaded the medieval Near East, even if those fully competent in their use and production were few. To deny this and assert instead a preference for perpetuating social hierarchies through biographical dictionaries is to make a virtue of a false necessity: there were documents, and more survived than is commonly understood. ${ }^{78}$

To be sure, the assumption that the document makes the archive exhibits several weak spots. By flattening out the archival divide, historians have contributed to equating collections of extant documents with actual archives. As we shall see, this idea has been overthrown by recent scholarship, which has in particular sought to take a closer look at the Islamic judicial archive found in the Haram al-Sharif, a trove of documents that belonged to a 14thcentury qādī in Jerusalem. The finding was initially saluted by scholars such as Bauden and Hallaq as material proof that Islamic archives did exist, and was first studied by Donald P. Little, who saw in it a qadi archive, although he later adopted a more cautious view. ${ }^{79}$ Although it is indeed larger than any other Arabic contemporary remains found to date, did the Haram papers really constitute an archive, or were they simply an accidental trove of judicial records? A lively debate has arisen around the nature of the collection; for reasons that will be addressed in the following pages, the verdict by authorities has been negative.

Together with his numerous studies of individual documents, Bauden sponsors a number of archeological, factual and materialist explanations for the

77 Rustow, "A petition to a woman at the Fatimid court", 3.

78 Ibid. 23 .

79 Little, Donald P., "The Significance of the Haram Documents for the Study of Medieval Islamic History", Der Islam 572 (1980), 189-219, Little, Donald P.: "Sidjill”, Encyclopaedia of Islam, Second Edition, IX, 538-545, 1996. 
absence of Islamic archives. Parallel to the alleged destruction of the Fatimid archives, he speculated on the end of the Egyptian medieval administrative collections. He argued that Mamluk archives were destroyed when the Circassian sultans acceded to power, an explanation based on a famous passage from al-Maqrīzī:

During the period between the end of al-Zāhir Barqūq's reign and before it was re-established [i.e., between $784 / 1382$ and $791 / 1389$ ] many affairs came into disorder, among them the matters of the chancery's room (qā'at al-inshā') in the citadel. It was abandoned, all the papers (awrāq) in it were taken, sold by weight, and the information contained in them was forgotten (wa-nusiya rasmuhā). ${ }^{80}$

The explanation cited above has been discussed by Hirschler, who convincingly demonstrates the limited role played by the chancery in the preservation of state records, and who argues that the decentralized nature of the Mamluk archives makes the hypothesis of an episodic loss unlikely. In 2013, Bauden further developed his views that archival documents vanished because they were recycled. ${ }^{81}$ Elaborating on the findings of Joseph Sadan, he mentions some interesting jurisprudence that reveals Islamic attitudes towards the ritual disposal of records potentially bearing the name of god (purification/ text-canceling by water, burying, etc.). ${ }^{82}$ However, Bauden's findings refer to the best ways to destroy documents bearing god's name, rather than patterns of record preservation, and interesting as they may be-and as Bauden himself agrees - they more support the idea that medieval Muslims did not have archives. If old legal papers lost their value for the living, documents could equally be compromising for the rulers. Ibn Faḍl Allāh al-'Umarī (m. 749/1349) narrates what happened with the sealed boxes left by a deceased man in Aleppo. They contained letters form the Zaydī imams of Yemen, hence threatening Mamluk sunni rule, and, accordingly, the governor ordered to have the letters ritually washed. ${ }^{83}$ Instead on targeting patterns of record preservation, these findings refer to archive-dismantling procedures. By the same token, the idea that paper had material value, and that families were therefore incentivized

\footnotetext{
8o Hirschler, "From Archive to Archival Practices", 9.

81 Bauden: "Du destin des archives en Islam", 42.

82 Sadan, Joseph, "Genizah and genizah-like practices in Islamic and Jewish traditions. Customs concerning the disposal of worn-out Sacred Books in the Middle Ages, according to an Ottoman source", Bibliotheca orientalis 43 1-2 (1986), 36-58. 
to sell it, goes more in favor of Chamberlains' argument, than they support Bauden's own stance.

The only procedural practice that might potentially have led to the nonsubsistence of records is the abandonment of the Fatimid archival practices mentioned by Bauden, which sought to preserve diplomatic correspondence. This idea is based on a statement by al-Qalqashandi that copies were kept in ad hoc registers, and that this practice ceased under the Mamluk administration. ${ }^{84}$ Indeed, other Mamluk authors confirm that hiatuses in archival and scribal practices were common. If al-Qalqashandī mentions that the collection of diplomatic missives was not continued under the Mamluks, our last and most important fifteenth-century informant from inside the Chancery, al-Saḥmāwī, alludes to another significant hiatus in the preservation of chancery material. Mamluk clerks were expected to report the drafts (musawwadāt) they prepared in a more formal register, the daftar - which, as we have seen above, was an artifact that kept track of scribal production, and for which various procedures had been put in place to secure it against forgery. According to al-Saḥmāwī, under the sultanate of al-Zāhir Barqūq, the drafting of copies in the daftars was abandoned for several years, and clerks "limited themselves to the production of drafts." ${ }^{85}$ The practice of keeping updated daftars containing all important documents was reinstated by Qadi Nāșir al-Dīn al-Bārizī, when he joined the administration of sultan al-Mu'ayyad Shaykh (1412-21), and of whom he was an active supporter. Al-Bārizī is remembered as a leading expert in chancery matters and was appointed archivist (khāzin al-kutub); significantly, not of any state department, where such a charge never existed under the Mamluks, but of the Mu'ayyadiyya madrasa's library. ${ }^{86}$

It is by collating several case studies that El-Leithy supports his claim that Muslims produced and preserved records with the same intensity as their Western counterparts. As mentioned previously, his aim is to dismantle Chamberlain's thesis that the social norms and cultural attitudes popular among the Arabs made records less important than in the West. ${ }^{87} \mathrm{He}$ first does this by

84 Bauden: "Du destin des archives en Islam", 34-5.

85 "fī ayām al-Ẓāhir Barqūq tarakahu wa iqtașara 'alā al-musawwadāt", al-Saḥmāwī, alThaghr al-bāsim, Vol I, 375 .

86 Martel-Thoumian, Bernadette: Les civils et l'administration dans l'État militaire mamluk (IXe/XVe siècle), Damas: Institut Français de Damas, 1992, 250-1, 258. The function of the khāzin al-kutub is described by Abū Ḥāmid al-Qudsī (d. 1483): Badhl al-nasā̉ih alshar'iyya fì mã 'ala l-sulțān wa-wulāt al-umūr wa-sāîr al-rāìyya, MA thesis, Riyadh, edited by Sālim al-Shamarī, 2 vols. Vol. 1, 1996, 226.

87 El-Leithy, "Living Documents, Dying Archives: Towards a Historical Anthropology of Medieval Arabic Archives". 
arguing that actors may have conspired to burn the evidence, as was the case for a notarial document where a religious conversion was attested. Secondly, he presents the same surviving petition from a Jewish woman advanced by Rustow; however, we know that this was a model document to guide scribes in the composition of similar requests. Thirdly, he dwells on an example, presented by Bauden, of a reused piece of paper that al-Maqrīzi retrieved from the ashes of the Mamluk archives. And indeed, Bauden has demonstrated that alMaqrīzī systematically contributed to the destruction of chancery collections, with no less than 509 pages of 14th- and 15th-century originals reused in his own manuscripts. ${ }^{88}$ As a result, the reader is left with documents destroyed on purpose, documents that owe their survival to their value as formularies rather than for their actual contents, and finally, with recycled records that are only extant thanks to the physical medium they were written on. Although less blatantly than in Bauden's case, the arguments advanced by El-Leithy to justify the lack of archives do not seem to support the idea that clerical, serial procedures leading to the preservation of collections did actually exist - at best, they explain why collections were short-lived.

Although accidents did happen, and fortuitous destruction, just like random preservation, does account for the disappearance of some document troves, we cannot assume from there that they go any way to proving that record preservation was systematically put into practice. One of the key documents for this research tells the story of several Frankish debtors in medieval Béjaïa in Algeria, and how they dealt with the problem of archived documents. They owed money to a resident Genoese merchant, and both parties had their contracts notarized before the local, Islamic 'udūl. Presumably, the Arab notaries delivered copies to the parties, however they did not keep a personal copy or original deed, since their validity resided in the presence of witnesses who could potentially be summoned to court. The debtors managed to destroy the documents in the creditor's house, which left the latter with no evidence to exhibit back in Europe. The story has come down to us through the preservation of Genoese notarial archives; the victim, indeed, reported his story to a local notary sometime after, whose protocol has obviously been preserved in the state archives. To be sure, the episode raises as many questions as it answers, however it is the contrasting attitudes towards preservation that are most problematic and difficult to ignore. ${ }^{89}$

88 Bauden: "Du destin des archives en Islam", 37-9.

89 See the discussion later in this section, Archivio di Stato di Genova (hereinafter ASG), Notai Antichi, 871, doc. 295, 296. 
However important forgery and episodic loss might be, such phenomena can hardly account for the complete absence of medieval archives. It is significant that many of the notarial documents edited by papyrologists and other researchers either belonged to vade mecums or notarial handbooks, or were found in the recipient's archives, ending up in faraway locations such as Venice. What sources suggest is that, at best, notaries and clerks kept records on an ad hoc basis - as was the case for the extensive diplomas they included in the encyclopedias and administrative handbooks they produced - or for the personal archives of scribes and judges. None of the practices described abovevoluntary destruction, the use of formularies, and recycling practices-are sufficient in themselves to identify a preservation logic that might actually support the existence of an archival culture.

A passage by Ibn Khaldūn, in his description of Egypt's judicial system in 1400 , has often been used to support the idea of a medieval archival tradition. In it, he claims that notaries "serve as witnesses when testimony is to be taken, testify during a lawsuit, and fill in the registers (sijillatt) containing the rights, possessions, and debts of people and other (legal) transactions. ${ }^{90}$ Apart from the fact that prior to Ottoman domination such registers have not survived, the sijill in this context should not be understood as an archived artifact, but instead as a single-document court decision comprising a series of court proceedings. A more telling narrative can be found in the attempts, more than a century later, by the Ottoman administration to gather together the records produced by local 'udūl. Ibn Iyās describes the large-scale judicial reform undertaken in Egypt during the years 1521-1522, which included a pyramidal refashioning of the judiciary—with the hanafi qadi at the summit of the hierarchy of legal schools - the transfer of notarial activities to the courthouses, and the requirement for local judges to incorporate their deeds into the sijills, or court registers, now subjected to archival procedures. Extant Cairo sijills begin in August 1522, ${ }^{91}$ but more interestingly, the documents deposited by the few notaries that complied with Ottoman injunctions were produced in the last years of Mamluk domination, and in some cases date back to $1505 .{ }^{92}$ These deeds constitute, to my best knowledge, the only Mamluk notarial material transmitted through the bias of an archival institution and not as the right-holder's personal

9o Ibn Khaldūn, 'Abd al-Raḥmān (1332-1406), Muqaddimat Ibn Khaldûn. Prolégomènes d'Ebn-Khaldoun, edited by Etienne Quatremère, 3 vol, Paris,: Institut impérial de France, 1858,405 .

91 Michel: "Les Circassiens avaient brûlé les registres", 253-4, n. 94.

92 Meshal, Sharia and the Making of the Modern Egyptian, 112-3. 
belongings. The kind of deeds that both Ibn Khaldūn and Ibn Iyās refer to were those notarized in court, rather than those drawn up in the streets and markets by private 'udūl, and for which, as made clear by the Genoese merchant in Béjaïa, notaries did not keep the originals. However, when acting as attachés to courts of justice and administrations, these notaries left traces of the records they produced, and we have reason to believe that registers, if they were preserved at all, were kept by qadis and notaries in their private residences for personal reference.

The most illuminating example of the how official administrative documents were stored and preserved in their lifetimes is a visit undertaken in 1387 by a Venetian consul to several administrative departments in Mamluk Alexandria. The consul's report offers precious insight into the actual functioning of the Mamluk customs administration, and sheds light on notarization practices and the handling of records. The consul, Luigi Morosini, acting at the request of Florence's principal commercial tribunal, the Giudici di Mercanzia, was assisting in an investigation into the activities of a Florentine merchant, Michele di Francesco, in Egypt. Wishing to know about Michele's purchases of diamonds and pearls, the court asked the Venetian consul to dig through the archives in search of tax and commercial records. The Florentine document describing his findings is unique, as it depicts actual scribal practices, and because the right-holders in this case were Frankish merchants, it does so from a cross-confessional perspective. The consul first went through the customs books, mostly to find out whether the Florentine had concealed evidence of these purchases. It is unclear, however, who actually owned the records. It may be that a first group of accounts was held by an official, called the mustawfi (per libros dogane mostafi alexandrie). Within the same department, the consul checked the books where Islamic notary-witnesses recorded transactions-in the weighing office, or qabbān (pro libros dogane testium gabani in quibus mercata scribuntur). ${ }^{93}$ Then the Venetian moved on to check the private accounts of a Muslim merchant, with all probability Burhān al-Dīn Ibrāhīm Ibn 'Umar al-Maḥallī (d.1403) (in libris Brandin Elmaeli pro barata perlarum). A different group of 'udūl operated elsewhere in the customs house, in an area known as the Duchela, and their books were also checked by the consul. In passing, we learn that al-Mahallī, an important businessman and diplomat in the service of the sultan, had Syrian Christians in his staff, and indeed we know that Oriental Christians were traditionally employed by the Mamluk customs ( feci 
perquiri libros testium duchele et libros ac scripturas brandim elmaeli quas habuit quidam christianus della cintura scriba ac factor supradicti brandim el maeli). ${ }^{94}$ More records belonging to al-Mahallī, apparently not included in his books, were handed over by a scribe called Mina, as well as excerpts from the books of a Christian clerk working for the fiscal administration $(\mathrm{Co}-$ pia delle scripture extracte deli libri de Mene Cristiano che riceve lentrata del soldano in quanto spetta alle ragioni de michele de Francesco da Firençe). ${ }^{95}$ Finally, we learn that sworn testimony was taken from both Christians and Jews, "according to their laws."96

At several points in the Florentine document, it is mentioned that both tax officers and notaries kept books (Copia delle scripture extracte di quaderni de Mene cristian scrivan aricevere lentrade de soldan; Copia delle scripture extracte de quaderni di testimoni dal gaban che scrive li mercadi), excerpts of which could be handed over to the right-holders upon request. However, the document does not mention a specific physical place where these records were deposited, and nor do other Venetian deeds depicting similar inquiries at the customs house. Instead, they suggest that books and records were kept by the same scribes that produced them; and indeed the consul had to return twice to check the deeds drawn up at the Duchela and, again, twice to check on the tax records, as if they were not held in the same place or could not be consulted all at once. As Nicolas Michel has demonstrated for the Mamluks, treating records as personal effects was established practice, and this has been confirmed for other Islamic polities. More importantly, the 1387 document confirms Ibn Khaldūn's assessment that, although the 'udūl did preserve some kinds of records, what we are dealing with here is notaries acting as attached to an administration and not as regular witnesses, and there is no trace of an institutional repository. Secondly, the document mentions that mere scribes, mostly Christian, worked alongside proper Islamic 'udūl, hence it is clear that two different levels of truth-bearing were at work in the customs house. Third, the taking of oaths and widespread recourse to the 'udūl, instead of relying on

94 al-Ashqar, Muḥammad 'Abd al-Ghanī: Tujjār al-Tawābil fì Mișr fì al-Așr al-Mamlūkī, Cairo: al-Hay’ah al-Mișrīyah al-Āmmah lil-Kitāb, 1999, 115, Fischel, Walter J., "The Spice Trade in Mamluk Egypt: A Contribution to the Economic History of Medieval Islam", Journal of the Economic and Social History of the Orient 1 (1958), 157-174, 169, BehrensAbouseif, Practising Diplomacy in the Mamluk Sultanate: Gifts and Material Culture in the Medieval Islamic World, 43-4.

95 ASF Mercanzia 212, deliberazioni, 1387, 72 v.

96 "Item muse çudio dito borgno dise avere conprado da Michel de Francesco panni ... li qual lui dise avere dadi a bet melo per lo dreto del soldan e questo çuralo per la soa fe", ASF Mercanzia 212, deliberazioni, 1387, 77r. 
the services of rank-and-file scribes, point to the fact that many administrative issues were recorded 'judicially', this is, in ways compliant with Islamic law and in a manner compatible with judicial evidence.

When dealing with the materiality of records, the debate on the archival divide exhibits three serious biases. First, there is an ideological willingness to redeem the Muslims of the anathema of being a people without archives. It is clear, however, that medieval administrations and law courts relied on their own production of records that were kept for reference, and that this was entirely possible without necessarily leading to long-term storage, or to the adoption of archive-building policies. In part, this was due to the fact that some transactions, such as business deals between Franks and Muslims, had to be notarized and therefore fell under the sphere of competence of the 'udūl, who were reluctant to surrender their records, if they had any. This proved to be true in 1521, when the Ottoman rulers called on Cairo's notaries to deposit any records, such as marriage deeds, that were subject to taxation, and almost none complied. Islamic deeds could not be endowed with public faith without the oral support of their authors, and for notary-witnesses depositing their deeds in an archive may have meant losing their personal monopoly over truth-bearing in society, now transferred to perishable objects. There was therefore no motivation to build archives of notarial protocols, as was the case for Latin Europe. In many cases, unfinished notarial business was followed up by a notary's sons, which meant that the 'udūl class was often made up of notarial dynasties - a fact that echoed the widespread assumption that trustworthiness was a family feature and resided in lineage. Jār Allah Ibn Fahd (1486-1547), who indulges in long descriptions of the 'udūl milieu in Mecca, suggests that notaries were more concerned with taking over their predecessors' affairs than in inheriting potential document collections. He reports the story of Khawājā Ibn Qawān, a merchant charged by the sultan of Gujerat with the endowment of a religious foundation on his behalf. When Ibn Qawān's notary died in the process, he had recourse to the scribe's son, since he had already paid the fee to the deceased father. The son took advantage of this to request a supplementary fare (ujra), claiming that whenever his father owed the Indians money, they should file a complaint against his last will. The resulting deeds (mustanadāt) were sanctioned by the Ottoman-sponsored, hanafi qadi, and it is clear from Ibn Fahd's narrative that clients, and the handling of sensitive transactions were, all too often, left in the hands of legal agents and their dynasties. In the case in question, Khawājā Ibn Qawān had already invested money in some buildings and needed the notarial agreement to have them converted to a tax-exempted, religious foundation, in order to avoid being left with a bunch of houses in Mecca, a circumstance used by the notary's 
son to blackmail his client. ${ }^{97}$ Be that as it may, a number of factors conspired to keep notarized deeds in the realm of memory or, at best, in the personal collections of notaries.

A second bias in the debate is the confusion between, on the one hand, the production and use of written artifacts and, on the other, their preservation. Apart from arguments such as those advanced by Sauvaget on the poor legal value of the written word, the debate has quickly shifted away from the logic of how people preserved information. Readers of European history, for instance, would find the assertions by Hallaq and Hirschler puzzling, which take it for granted that documents "lost their legal value," and that there was therefore no need to preserve them. Just as astonishing might be the repeated mantra that collections ultimately ended up in the private hands of qadis and scribes, rather than in institutional repositories. It is clear at this point that, whether the materialist explanations are convincing or not, the idea of preservation that is conveyed in these studies greatly differs from that which underlay the creation of European judicial and state archives.

Lastly, the debate has little to gain from the way in which the nature of documents is considered, taking several different kinds of records from the same standpoint, when in reality they looked very different from each other in the eyes of early modern Muslims. Particularly risky in this regard is the equal treatment given to notarized deeds and other documents that could be recorded by mere scribes, and even by unbelievers not endowed with sharīa notions of trustworthiness.

\subsubsection{Non-Materialist Explanations}

A more productive line of investigation is one that runs parallel to the quest for material explanations. The pioneering 1998 article by Wael Hallaq ${ }^{98}$ shows that since early Islam some kind of documentation was being produced and temporarily preserved by the qadis. Less convincingly, Hallaq goes on to question the very idea that archives started with the Ottomans, and stresses that there was a continuity between modern and medieval practices. As regards Islamic patterns and ideas of record preservation, his denial of any Ottoman innovation is not backed by any of his own evidence, even though he acknowledges that, with some exceptions, the Ottomans began to systematically bind

\footnotetext{
97 Ibn Fahd, Jār Allāh Muhammad Ibn 'Abd al-'Azīz al-Hāshimī (1486-1547): Kitāb Nayl alMuná bi-Dhayl Bulügh al-Qurá li-Takmilat Ithāâ al-Wará (Tārīkh Makkah al-Mukarramah min Sanat 922 H ilá 946 H), edited by Muhammad al-Ḥabīb al-Hīlah, 2 vols., Beirut: Mu'assasat al-Furqān lil-Turāth al-Islāmī, 200o, 258-9. 
the records, and certainly provided official storage for the qadi's dīwān..$^{99} \mathrm{Be}$ that as it may, Hallaq's article represents a landmark in our understanding of the origins and evolution of the judicial collections, mainly because it has provided a thorough analysis of the transmission of judicial archives from one qadi to his successor. By so doing, Hallaq acknowledged that the qadi archives did exist, but were of a temporary nature, and were not fully transmitted to the new judge, and that this transfer did not correspond to any long-term preservation pattern.

The most fruitful approaches to non-materialist explanations began as a reaction to Hallaq's work. Although he could probably have made this argument more explicit, Konrad Hirschler has deviated from the traditional attempt to justify a lack of archives, to delve instead into the complexities of Mamluk administrations. Documents, he argues, were used in many aspects of daily life and preserved by institutions, according to different logics. Quite forcefully, his article engages in a description of the polycentric, decentralized, and even transportable nature of the Mamluk archives. As mentioned before, the end of the Abbasid caliphate witnessed the advent of feudal-like military states, funded trough land allotments, called iqțāa and based on a different, non centralized administrative logic. Mamluk officers enjoyed iqțāa grants attributed by the sovereign; however, as these allotments were not fixed the fief-holder could potentially be transferred to a different location in Egypt, and hence an officer would bring his personal archives with him. The army administration produced and stored a great many state documents, as did, I might add, the Sultan's department (Dīwān al-Khāșș). According to a recently discovered memorandum containing information on Mamluk links with India and Southeast Asia, it was the Dīwān al-Khāșș, the sultan's privy department in Cairo supported by its own postal service, that handled data collected by custom officers as far-flung as Jedda. ${ }^{100}$

Much as Hallaq has demonstrated the complexities of the qadi archive, Hirschler has turned his attention to the way documents were produced and temporarily preserved by different state actors. Apart from illustrating documentary practices, as regards the archival divide Hirschler sees the production

99 "There is no suggestion that the Ottomans introduced any changes to the institution, save perhaps for providing a crucial public space for storing the documents.", Ibid. 436, Peirce, Morality tales: law and gender in the Ottoman court of Aintab, 98-102, Faroqhi: "Sidjill", Encyclopaedia of Islam, Second Edition, IX", Meshal, "The State, the Community and the Individual", 129-30.

100 Apellániz, Francisco, "News on the Bulaq: a Mamluk-Venetian Memorandum on Asian Trade, AD 1503”, EUI Working Paper HEC 2016/o1 (2016). 
of documents in high numbers as justification for discarding Chamberlain's thesis of a 'social' logic underpinning the non-survival of archives. ${ }^{101}$ One could well conclude that at best there were archives, but that they were short-lived, not only due to the hazards of preservation, but because they were never conceived as permanent structures and therefore not considered bound to last. In Hallaq's own terms, in pre-Ottoman times, "there is no hint whatsoever that the qadis, upon dismissal or death, were required to deposit their diwans, in any form or manner, in a state-owned building or other public space." ${ }^{102}$ Indeed, Hirschler admits that "there was only a limited institutional logic of document preservation and that documents were discarded when they ceased to be of relevance for the individual." Hirschler presents multiple patterns for temporary storage, and different logics of short-term storage. Yet as in the case for the qadi archives, he admits, it is difficult to draw a line between what constituted official state papers, and documents belonging to the personal collection of a clerk, whose interest in preservation was limited to his own work-hence diverging from a purported state concern for the safe-keeping of positive administrative knowledge.

Together with the quest for non-state archives and practices, the discovery of documentary collections in unexpected places has been summoned in support of a medieval archival tradition. This line of reasoning assumes that if recipients archived records, the authorities that issued them might have done so as well. Government decrees addressed to Christian monasteries such as those at Mount Sinai, scriptures buried in synagogues, text deposits entrusted to mosques as pious endowments, together with the remains of company records, all escaped the hazards faced by state archives and allegedly confirm that preservation was the norm. Apart from the obvious interest these collections present to historians, when it comes to defining the logic behind their preservation, specialists most often discard archival intentions. This is clearly Christian Müller's interpretation for the Jerusalem papers, Miklos Muranyi's conclusions on the library of the Great Mosque in Qayrawān, or Li Guo's understanding of the letters found in the Shaikh's house in al-Qusayr. For the case of the Cairo Geniza, the debate revolves around whether these records are simply sacred trash, or whether they survived due to institutional care and continuity. Discussing Geniza-like practices among Jews and Muslims, Joseph Sadan has admitted that when historians refer to these repositories as archives, it is more a figure of speech. In fact, he argues that "it is by no means clear that

101 Hirschler, "From Archive to Archival Practices", 27.

102 Hallaq, "The qādī’s dīwān (sijill) before the Ottomans", 435. 
putting material in a small storeroom at the Ibn 'Ezra synagogue in Old Cairo through an opening in the women's balcony on the second floor, or burying it at Basatin, implies any particular intention of depositing material, bequeathing it to posterity, or preserving it."103

The survival of the Cairo waqfiyya stands uncomfortably as the elephant in the room in the discussion about whether random deposits can really prove the existence of an established practice. The very existence of this archive, which brings together the endowment deeds of Egypt's pious foundations, forces us to acknowledge how important any logic of preservation is to ensuring archive survival. Citing the waqfiyya as a surviving prototype of the Islamic archive, many authors forget that waqf documents, unlike state papers, survived because Islamic welfare and the livelihood of most ulama depended on their preservation, as they described the resources that were to be attributed to the payment of clerks and religious functions. Religious foundations were intended to last long after the death of their founder-theoretically forever, indeed - and waqf records regulated the allocation of resources for generations of clerks and staff members to come. For this reason, waqf deeds played a crucial role in social reproduction and competition. They needed to be preserved, transmitted and validated through the procedure of isjāl, whereby new witnesses certified the authenticity of old authentications by previous witnesses. In gross, these documents took the shape of a scroll with additional sheets of paper collated to an original document, mostly subsequent isjāls, like the Saladin waqf deed (certified time and again for over five centuries), or the Damascene document published by Donald S. Richard that covers a period of two hundred and fifty-five years. ${ }^{104}$ Zomeño mentions an addition, dated 1488, to a 1432 document describing some properties in the Andalusian city of Baza. In it, two new witnesses identified the original witnesses' writing, and acknowledged they had been 'udūl in Baza and had maintained their honorability until they died. ${ }^{105}$ Endowment deeds, together with control of the foundation's resources, guaranteed the founder's offspring with the right

\footnotetext{
103 Müller, "The H̦aram al-Sharif collection", Muranyi, Miklos, "Geniza or hubus: some observations on the library of the great mosque in Qayrawan", Jerusalem Studies in Arabic and Islam 42 (2015), 183-201, Sadan, "Genizah and genizah-like practices in Islamic and Jewish traditions", Guo, Li: Commerce, Culture, and Community in a Red Sea Port in the Thirteenth Century: The Arabic Documents of Quseir. Leiden: Brill, 2004, 90-1.

104 Richards, D. S., "A Damascus Scroll Relating to a Waqf for the Yūnusiyya", Journal of the Royal Asiatic Society of Great Britain and Ireland 2 (1990), 267-281, 279, Salati, M., "Un documento di epoca mamelucca sul waqf di 'Izz al-Dîn Abû l-Makârim Hamza b. Zuhra alHusaynî al-Ishâqî al-Halabî (ca. 707/1307)", Annali di Ca' Foscari XxxıII, 3 (1994), 97-137.

105 Zomeño, "From Private Collections to Archives", 469.
} 
to maintain patronage relations with clerks and ulama. Thus, in contrast with more short-lived transactions, the Islamic judiciary took great care to preserve and transmit these records across generations and dynasties.

In contrast with what has become a commonplace in the genre, it is not my aim to engage here in a thorough analysis of the archival exceptions to Chamberlain's hypothesis. Rather, I propose returning to an argument by Sauvaget that runs parallel to Chamberlain's: that judicial documents, together with other notarized administrative documents were not legally valid beyond the life of their authors, and were therefore neither useful to any logic of governance, nor for social competition. In gross - and I will be returning to this issue-proof in a medieval Islamic context needed to be backed by personal knowledge and trustworthy witnessing, and therefore judicial and state papers only lasted as long as the human capacity to attest to their contents. In the remaining section of this chapter I will explore the works that have allowed us to better understand the logic of proof production in Islamic societies before Ottoman times. Notions and doctrines of proof did have an impact on the way documents were preserved; instead of attempting inductive reasoning by looking for explanations - materialist of not - that might account for an archival culture on the basis of actual remains, there is much to be gained in looking at the way such notions evolved over time. A thorough analysis of the epistemological grounds for proof has been provided, in the last decades, by Baber Johansen, who explored the norm, but also identified hiatuses and transformations in doctrines on proof and evidence. After sketching out a summary of this transformation, I will turn to the artifacts that embodied documents, such as scrolls, ledgers and bookcases, and to certain practices, such as archive transmission, that reflected these changing notions and ideas.

\subsection{Islamic Notions and Doctrines on Proof and Evidence}

In a series of articles dealing with late medieval attitudes towards proof and notarial evidence, the legal historian Baber Johansen coined a crucial notion: the "epistemological skepticism" characterizing Islamic law. Only god can know the truth, then the best that a qadi can do is to avoid sinful action by giving credence to doubtful evidence. The principal idea being that, due to the divine nature of the Law, records and other physical media can hardly be bearers of truth. Such physical media-i.e., three-dimensional objectshave a volume and are susceptible to trick the senses, and therefore are not reliable. In particular, a judge who chooses to put his trust in such fallible objects when deliberating on a verdict risks committing sin. It is only the word 
of a trustworthy Muslim that deserves to be taken into consideration in the quest for truth. Arguments against the written emphasized the defense of the illiterate, and discussed whether familiar handwriting could ultimately be recognized and trusted, even going so far as to question whether a judge should rely on his ability to correctly recognize his own calligraphy. Islamic law thus adopts a cautious approach: witnesses are interviewed, notarial deeds are backed by oral testimony, and even the judge's recourse to his own archives may require certification procedures. This was the mainstream, commonly adopted approach by medieval and early-modern jurists, against which innovative voices raised in specific times and places such as tenth-century central Asia or by some Mālikīs in the West. Whilst the skeptical approach of the "classic" Iraqi ḥanafĩ school was generally upheld, more innovative thinkers were inclined to exceptionally accept the records advanced by merchants, foreigners and governors. ${ }^{106}$ The written word was only resorted to with great caution, and throughout Islamic history, up to late Ottoman times, it was generally upheld that oral testimony was the proof par excellence. In daily practice, it was this epistemological skepticism that underpinned Islamic courts and their approach to jurisprudence, up until the 19th-century Ottoman legal reforms, when testimonial rights became a mainstay issue. ${ }^{107}$

Jessica Marglin has recently pointed out that, in the context of the 19thcentury Maghreb, and under the influence of Mâlikì doctrine, legal practice took a different direction, and notarized deeds began to be accepted more freely than in previous periods. This argument is based on specific Mālikī attitudes, such as their opener approach to the forensic examination of handwriting in order to determine the authorship of a document. ${ }^{108}$ Marglin demonstrates that, in Morocco, notaries testified through their signatures, and that judges generally considered documents to be written embodiments of oral testimony. Curiously enough, however, this "triumph of the written" did not lead to the development of judicial archives for legal papers, and in the Moroccan case such documents seem to have ended up in family collections. Although Marglin's research proves persuasive in illustrating Moroccan court practice, these opener attitudes to the written appear to have been confined to a very recent period. Instead of accounting for a new interpretation of the sharīa approach

\footnotetext{
106 Johansen, "Formes de langage", 369-371. Turki, Abdelmagid “Lisān al-dīn Ibn al-Hূațîb", 195.

107 Canbakal, Society and politics in an Ottoman town: 'Ayntab in the 17th century, 148.

108 Tyan, Émile: Le notariat et le régime de la preuve par écrit dans la pratique di droit musulman, Harissa: Imp. St. Paul, 1945, 76-7, Marglin, Jessica M., "Written and Oral in Islamic Law: Documentary Evidence and Non-Muslims in Moroccan Shari'a Courts", Comparative Studies in Society and History, 594 (2017), 884-911, 907.
} 
to truth, this example provides more a snapshot of a late 19th-century phenomenon, and Marglin does not attempt to explain why and when such attitudes led to a deviation from mainstream practice in the legal system. The extent to which these practices might account for Mālikī practice at other times and in other places is not free of contention either. Mālikì-dominated al-Andalus, for instance, never conceded to a similar triumph of the written, and case of the specific 19th-century Maghrebi attitude cited above stands more as an exception; thus such cases point more towards a general principle of mistrust for written evidence, than they do negate it. ${ }^{109}$ All in all, the exceptional character of late early modern Moroccan court practice is nevertheless intriguing, and more research is needed on the action of Māliki judges appointed in Cairo, Damascus and Jerusalem.

Léon Buskens has recently contributed to the discussion with a colorful description of his experience as a document collector in Morocco. It is clear from his narrative that, even in the presence of a burgeoning antiquarian market, old notarial documents were unanimously considered as useless and as the most difficult item to place for sellers. Buskens uncovers vernacular attitudes according to which deeds entered a kind of limbo state when their owners lost interest in them. Even if, in late modern Morocco, notarized documents had acquired independent value as legal proof-a question not addressed by Buskens- the standard procedure to make them invalid was cutting the 'udūl's signatures off. Making witnesses to the deed untraceable killed the truth contained in them, that dwelt entirely on the latter's endorsement. ${ }^{110}$

Yossef Rapoport has noted that in Mamluk times written documents could sometimes be accepted as valid elements of proof. In his seminal article on Mamlūk Siyāsa, he mentions in passing a clause contained in Mamluk appointment decrees, whereby "the Mālikī chief qadi is enjoined to apply his school doctrine so as to" - among other prerogatives - "permit the use of documentary evidence."111 This may mean that, at least in specific circumstances, Mālikī judges were allowed to base their judgement on this form of evidence, which was otherwise considered circumstantial. Legal historians have built on

109 Oulddali, Ahmed: "Recevabilité du témoignage du dimmī d'après les juristes mālikites d'Afrique du Nord", in: The legal status of dimmi-s in the Islamic West (second/eighth-ninth/ fifteenth centuries), Turnhout: Brepols, 2013, 275-292.

110 Buskens, Léon: "From Trash to Treasure: Ethnographic Notes on Collecting Legal Documents in Morocco" in: Legal Documents as Sources for the History of Muslim Societies, edited by P. Sijpesteijn, Maaike Van Berkel, et Léon Buskens, Leiden—Boston: Brill, 2017, 180-208.

111 Rapoport, "Royal Justice", 78. 
Emile Tyan's 1945 monographic work on notaries to point to a Mālikì tradition of openness towards written proof, as exhibited by authors such as Ibn Farhūn (1358-1397). Although he is best known for his work in Egypt, the Māliki jurist of Andalusian descent was also active in Medina in the Arabian peninsula, and was probably responsible for introducing notions of Mālikì doctrine in Egypt - a school that was hegemonic in al-Andalus and the Maghreb, but fundamentally marginal to Mamluk legal practice. An interesting testimony, although certainly an indirect one, comes to us from Francesco Suriano (14451481?), an Italian friar who had twice been appointed head of the Franciscans in Palestine, and who, in his Trattato di Terra Santa e dell'Oriente, exhibits a profound knowledge of the Mamluk regime, administration, and judiciary. Suriano describes a personal acquaintance of his, the Mālikì qadi in Jerusalem, who was of Maghrebi origin and shared the same legal background as the western Mālikī chief justices that were traditionally appointed to Damascus. ${ }^{112}$ Suriano's narrative presents the Mālikī judge on his deathbed, rather unsurprisingly using his last breath to renounce Islam in favor of Christianity. In his deathbed confession, the qadi repeatedly claims that he is all the more guilty because he had been abusing his office by forging written deeds. ${ }^{113}$

Many authors have argued that sharīa adopted the same legal dialectic for dealing with the affairs of unbelievers, as it did for Muslim subjects. In other words, it was not Islamic law that worked differently for unbelievers, but instead the formalist, religious-grounded bias against dhimmì witnesses that preceded legal reasoning, and therefore affected its outcome. Mario Grignaschi presents Ottoman legal attitudes as being marked by mistrust for the capacity of unbelievers to bear truth, rather than any unwillingness to grant them rights. ${ }^{114}$ And indeed, the literature describing complex cross-confessional

112 Za'rūr, Ibrāhīm, "al-Quḍāh al-Andalusīyūn wa-al-Maghāribah fĩ Bilād al-Shām fĩ 'Aṣr al-Mamālīk", Dirāsāt Tārīkhīyah 53-54 (1995), 59-79, Ben Mu'ammar, Muhammad "al-maghāriba wa manșab qāọī al-quḍḍat al-mālikī fì dimashq al-mamlūkiyya", Majalla al-ādāb wa al-'ulūm al-insāniya-Jāmi'a Dimashq (2008), 145-162.

113 "Infirmandose el Chadi Melechi, stete in transito da la matina sino a completa. Ritornato che lui fo in sè, disse asstante molta gente: Tristi nui Saraceni che tuti ne damnamo et io étiam sum damnato per le scripture che ho falsificato, e solum li Christiani se salvano. E chridando tuti che fosse arso, fo risposto propriamente, como habiamo dicto de quella dona de Damasco; et io lo cognobi et pocco avanti ch'el morisse, gli parlai. Tandem dicte che l'hebe quelle parole, immediate morite; e confessò lui dover haver mazor pene de l'altri, per l'instrumenti e carte che lui havia falsificato." Suriano, Francesco: Il trattato di Terra Santa e dell'Oriente, edited by Girolamo Golubovich, Milano, Tipografia editrice Artigianelli 1900, 216.

114 Müller, Christian: "Non-Muslims as part of Islamic law: Juridical casuistry in a fifth/ eleventh-century law manual," in: The Legal Status of Dhimmis in the Islamic West, edited 
debt cases, involving dhimmīs, not mustā’mins, is abundant. For example, we know from this literature that the Muslim creditor of a deceased infidel has precedence over a Christian one, if both rely solely on Christian witnesses, however this right of precedence can be superseded by the Christian creditor if this latter is able to produce Muslim witnesses.

It seems that for most late medieval and early modern polities, and particularly in the territories under the Ottoman umbrella, priority was given to safeguarding the formal standards of the judge's decisions and their compliance with religious principles. What happened, then, if the testimony advanced in court was false? Johansen argues that lying made a witness a sinner who would be punished in hell. Yet even when a witness admitted he had lied during a trial, if the decision by the judge had been taken on appropriate formal grounds it needed to be upheld, although the lying witness was considered deserving of punishment. ${ }^{115}$ More importantly for the present study, formal preconceived notions heavily affected the witness system, thus impacting the way diversity was dealt with. Collections of fatwās dating from the early modern period offer many examples of what ought to be done in cases where witnesses exist, but none comply to Islamic standards. This problem is epitomized in a hypothetical case whereby the only Muslim inhabitant of a Christian village murders a Christian. In such an eventuality, the Muslim could never be convicted on the basis of Christian witnessing, because one of the basic prerequisites for the judge to trust a witness resides in his being Muslim. If, as a system of legal reasoning based on rules and principles, Islamic law did not discriminate, the biases against non-Muslims preceded and impinged on the application of these very principles, hence conditioning the system's outcome.

The Islamic formalism that underpins Johansen's analysis of biases against non-Muslims had an obvious impact on the artifacts used to bear witness. The nonexistence of archives was indeed intimately tied to the issue of preserving and transmitting truth. Since in practice it was people, and not objects, that were considered to be the depositaries of earthly truth, the only means for transmitting it over time was through an uninterrupted chain (ittișāl) of witnesses, as in the isjāl procedure that provided for the certification of endowment deeds, as described above. ${ }^{116}$ In order to be valid, documents underwritten by long-dead

by Maribel Fierro and John Tolan, 2013, 21-65, Grignaschi: "témoignage des sujets non musulmans".

115 Atçil, Abdurrahman: Procedure in the Ottoman court and the duties of kadis, M. A. Thesis, Bilkent University: the Institute of Economics and social sciences of Bilkent University, 2002, 76, Johansen, Baber, "Le jugement comme preuve. Preuve juridique et vérité religieuse dans le Droit Islamique Hanéfite", Studia Islamica 72 (1990), 5-17.14-5.

116 Johansen, "Formes de langage", 349. 
witnesses had to include verification of the original signatures by currently living witnesses. When transmitted to a newly-appointed judge, the medieval, qimatr-like, 'qadi archive' only contained the few pieces that needed to be submitted to this recertifying procedure. For this reason, endowment deeds, which needed to last over generations, were recertified time and again by new cohorts of witnesses in scroll-shaped documents. ${ }^{117}$ It is no coincidence that the only proper archive that has survived in Egypt is a waqfiyya, or repository of deeds relating to the functioning of pious foundations, on which successive generations based their decisions regarding the appointment and funding of charges. Endowment deeds are a kind of document bearing numerous isjāls, examples of which are well known. The recertifying procedure has been documented until late modern times by anthropologists, although some authors have raised doubts about whether the procedure was seriously implemented, as it seems that the chain of transmitters was sometimes broken. Even if, on occasion, incomplete chains of certifications were accepted, accepting these documents was always problematic for jurists. "You permit the testimony of a man after his death, if you found his signature on a document," argued a Mālikī jurist in ${ }^{1}{ }^{\text {th-century Iberia. }}{ }^{118}$ In this sense, Ottoman judicial practice represented a groundbreaking deviation from this medieval procedure, as all pieces included in the sicil were considered as certified once and for all, and therefore no further confirmation by witnesses was needed. ${ }^{119}$

Ultimately, as Johansen has developed elsewhere, the formalistic approach to proof was rooted in the epistemological skepticism of Islamic law. Proof, including trustworthy witnessing, was a power put into play by either party in order to alter the conditions of the world of appearances. Truth ultimately belonged to God, while the judge was fundamentally incapable of attaining the inner (bāțin) truth of existence; he was thus obliged to rely on fallible utterances in order to safeguard justice and other earthly aims. ${ }^{120}$ Johansen's work, therefore, delves into the moral dimension of proof-production, and in so doing yields a better understanding of its abiding framework. The regime of proof, which ultimately determined the fate of written documents and the

117 Müller,Christian, "ALegal Instrumentin theService of PeopleandInstitutions:Endowments in Mamluk Jerusalem as Mirrored in the Ḥaram Documents", Mamluk Studies Review 121 (2008), 173-191, 184, Richards, "A Damascus Scroll Relating to a Waqf for the Yūnusiyya".

118 Marglin, "Written and Oral in Islamic Law: Documentary Evidence and Non-Muslims in Moroccan Shari'a Courts", 108.

119 Müller, "The Ḥaram al-Sharîf collection", 458.

120 Johansen, "Le jugement comme preuve. preuve juridique et vérité religieuse dans le Droit Islamique Hanéfite". 
biases against minority witnesses, was anchored in Islamic epistemology, and not simply the result of practical choices.

Legal practice partly developed out of a highly formal and theoretical context. In a pioneering work published in 2002, Johansen also addressed the daily difficulties encountered by rulers and their delegates in the application of justice. He explored the works of theorists dealing with the so-called secular, political dimension of justice, or Siyāsa, which will be addressed in Chapter Three. Siyāsa has existed since the time of the caliphs, as a branch of jurisprudence devoted to empowering the ruler with legal solutions for the conduct of governance within the rule of law, particularly in areas upon which sharīa remains silent. Siyāsa was all the more important in that-beyond its spectacular development in Mamluk times by the hanbali jurists of Damascus-it played out in real court practice and "Siyāsa" judges heard, among other areas of interest, cases involving the Franks. Commenting on the ideas of Ibn Farhūn and Ibn Qayyim al-Jawziyya, Johansen has painted a dynamic picture of Islamic jurisprudence in the "post-classical" period (according to his own periodization), notably through the study of doctrines of governance, arguing that sharīa did not only work under the ideal framework of epistemological skepticism, but could also operate in a context of 'altered normativity', or, according to a later formulation "a perverted law" (al-sharc al-mubaddal). In plainer words, daily governance was at odds with the narrow dictates of sharīa described above, and accordingly, jurists labored to provide the ruler with a more operational framework for investigating the truth and inflicting punishments, in situations such as one in which witnesses deliberately lie in order to obtain an unfair ruling. ${ }^{121}$

Just as he has demonstrated that jurists sought to adapt sharīa to practical governance, Johansen has also explored the limits of the formalist approach to proof, observing the problems hanafis encountered when attempting to maintain the doctrinal unity of their school. He focuses in particular on the central Asian doctrines dating from the 1oth-12th centuries, which addressed the legal value of the use of direct speech in legal writing, and the status given, for example, to private documents written by merchants. This "Transoxiana school," epitomized by legal thinkers such as al-Sarakhsī, emerged in a context marked by long-distance trade and a dominant written culture. As we shall see, these thinkers set precedence on regulating dealings with unbelievers, extending their reasoning not only to dhimmīs but also to foreign unbelievers,

121 Johansen, "A Perfect Law in an Imperfect Society", 265. Johansen, Baber, "Signs as Evidence: The Doctrine of Ibn Taymiyya (1263-1328) and Ibn Qayyim al-Jawziyya (d. 1351) on Proof", Islamic Law and Society 92 (2002), 168-193, 182. 
or harbīs. They fashioned a more open attitude towards written evidence, and were inclined to consider not only notarized deeds but also authoritative documents as proof, such as those emitted by rulers and administrators, even in the absence of oral certification. ${ }^{122}$ By the fourteenth century this had become common practice, and examples of uncertified documents issued by authorities have been found among the Jerusalem papers, as elements used in support of the judge's rulings. ${ }^{123}$ Indeed, although Johansen focused on some developments within the hanafî school, from Abbasid to late medieval times, some views of innovative hanafis, such as the attitude towards archived documents, were shared by other jurists, including the hanbalīs, who were influential under the Mamluks. Ibn Qayyim agreed with the hanafis in that testaments ought to be accepted, as well as the qadi's right to rely on his own personal archives. ${ }^{124}$ Denying value to last wills, Ibn Qayyim argued, was in overt contradiction with the reliance on writing and copies for matters as important as God's Revelation, of which only the first generations of Muslims had had direct experience.

Johansen traces the genealogy, extending out from central Asia, and going as far back as Abbasid times, of important issues on proof and procedure in Islamic law. He has showed that the hanafĩ school fostered an opener attitude towards the use of the written, without actually challenging shari`a evidentiary standards and its reliance on the oral performance of trustworthy Muslims. Through his attention to chronology and changes over time, Johansen's works has given us a better understanding of the norms governing proof and evidence and helped uncover their epistemological and religious roots, but also set a line of demarcation between the normative sphere and the priorities of Islamic governance. These priorities materialized in theories such as the Siyāsa doctrine, which challenged the normative-centered view of Islamic law and acquired relevance under the Mamluks. Johansen also explores the evolution that theories of governance underwent over time, shaped first by mālikiss and later by hanafîs, and hence provides us with a better understanding of specific late medieval attitudes towards Siyāsa. Finally, Johansen's overview points to the meager value of the archived document. Significantly, it is in this context that late medieval Siyāsa thinkers, such as the disciples of Ibn Taymìyah, raised

122 Johansen, "Formes de langage", $365-374$, Johansen, Baber, "Le contrat salam: Droit et formation du capital dans I'Empire abbasside (XIe-XIIe siècle)", Annales. Histoire, Sciences Sociales 614 (2006), 863-899 Johansen, "Signs as Evidence".

123 Müller: "Ecrire pour établir Ia preuve orale en Islam: Ia pratique d'un tribunal à Jérusalem au XIVe siècle", 77 .

124 Ibn Qayyim al-Jawzīyah, Muḥammad Ibn Abī Bakr (1292-1350): al-Ṭuruq al-ḥukmīyah fi al-siyāsah al-shar'īyah, Mecca: Dar al-'Alim, 1428 h, 544-568. 
objections against the generally-accepted framework and called for an opener attitude towards testaments and other written records. ${ }^{25}$ Such claims are all the more important when we consider that Siyāsa materialized in Mamluk times, in the courts that were in the habit of judging issues concerning foreign merchants, and which necessarily had to deal with evidence produced by unbelievers. As far as sharīa-based norms were concerned, however, the status of records and archives remained unvaried throughout medieval times. Although materialist explanations for the lack of collections suggest that qadi archives existed but have been lost, a closer look at the issue of archive transmission demonstrates that medieval legal theory never supported such a view.

\subsubsection{Archive Transmission}

As mentioned previously, in a context where orality was widely accepted, a legal act created with the intention of surviving over several generations needed to be transmitted by an uninterrupted chain of witnesses. In this context, two detailed investigations into archival transmission by Johansen and Hallaq, published in the same year, have proven crucial; both make it clear that, even though some archives were transmitted from a judge to his successor, this did not imply that all records were still valid. Indeed, Hallaq has demonstrated that the qadi's archive was not systematically copied and certified in its totality by his successor. We know from descriptions in handbooks for judges, by the jurists al-Khașsāa (d. 874) and Ibn Abī l-Dam (d. 1244), how qadis transmitted their records to their successors. To put it in very rough terms, the qadi's archives could not be handed over to the new judge without him guaranteeing the chain of transmission for every single document. ${ }^{126}$ Limitations to relying on personal archives could also affect a qadi if he was temporarily dismissed from his office and subsequently reinstated.

125 Ibid., 232.

126 Johansen, "Formes de langage", 350-1, "We should recall here that not all cases were copied down in the incoming qadi's diwān. Those which have become inconsequential because they are considered, for example, old (where all the concerned parties have died), would expectedly be left out. This practice has the important implication that the bulk of the diwan's material did not grow cumulatively but was constantly subjected, at the stage of copying, to a measure of trimming", Hallaq, "The qādī's dīwān (sijill) before the Ottomans", 435, n.16, "The Ayyubi judge Ibn Abī l-Dam (d. 642/1244) says that the dīwān al-ḥukm containing mahạạiir and siğillāt was handed over to the successor who had to scrutinize (tașaffaha) whether the witnesses to these documents were still alive. In that case, there was no need to renew authentication (ithāt). However, if most witnesses were dead and only two of them alive, the judge had to summon them for authentication at his court, Müller, "The Ḥaram al-Sharif collection", 456 . 
Previous witnesses bore testimony for both the document and its contents to the new witnesses that succeeded them. The new judge "who wished to take over his predecessor's papers" needed to send two trustworthy Muslims who could certify every single record, in the presence of the former judge. What is more, they needed to ascertain whether the witnesses to these legal deeds were still alive; if there were only two surviving witnesses, they needed to be summoned to court to authenticate a claim. The crowning example of this procedure is the founding act for the sufi convent established in Jerusalem by Saladin, whose certification was renewed from 1187 to $1614 .{ }^{127}$ In the middle ages, unlike in more recent times, the probity of witnesses was a concern of the judge, and specific procedures had to be respected to ascertain their trustworthiness. ${ }^{128}$

The preservation of judicial records, even if they constituted real archives, was seriously compromised by the supremacy of orality, and the fact that the judge needed to have firsthand knowledge of each document's validity. As it could not be otherwise, only a minority of records was considered of future interest and therefore submitted to the re-authentication procedure, and the rest were discarded. With this analysis of the procedure by al-Khașșāf, Johansen never inferred that judicial archives actually existed; rather, he underlined the fact that most notarized deeds lost their validity when the qadi ended his tenure, and found their way, at best, into the private collections of legal practitioners and litigants - where they have been found today — but not into archives. Specialists in legal practice and procedure have loosely assumed that the qadi archive did actually exist for an undetermined timespan, to have been a temporary repository, and to have followed a logic of preservation that greatly differed from Western practice - which, as we shall see, was based on the late medieval legal fiction that notarized records were vested with publica fides. For his part, Hallaq has interpreted this contingent storage of judicial papers as a real institutional repository, and levelled differences between the temporary collections held by the medieval qadis and the Ottoman sicils systematically kept in courthouses. While I must stress that he provides the reader with some particularly innovative insights, Hallaq's vindication of the medieval Arab archive is unpersuasive, because he provides the reader with no proof of such continuity; he denies the Ottoman practice of collecting court proceedings in bound ledgers and, paradoxically, pushes

127 Müller, "A Legal Instrument in the Service of People and Institutions", 184. Müller, "The Ḥaram al-Sharīf collection", 458, n. 148.

128 Tyan, Émile: Histoire de l'organisation judiciaire en pays d'Islam, 2 vol, Paris: Librairie du Recueil Sirey, 1938, I, 354-7. 
the invention of the register back to late Mamluk times, a claim not backed by any evidence. ${ }^{129}$

\subsubsection{Was the qimatr an Archive?}

The tendency to equate documents with archives has found its clearest embodiment in the archival artifact called the qimaț. The qimațr is documented as having been the mobile archive of early judges, who held sessions in changing locations, as no such thing as a courthouse existed at that time. It came in different shapes and forms-a simple bag, a basket or a wooden box-and contained the certified documents described above, validated by living witnesses known to the court and to the judge in charge, and therefore ready for use in open cases. The surviving inventories, reports and depositions identified as part of court proceedings were not actually included in the qimațr, which was more a movable repository than it was an archive. In gross, as a mobile repository containing a selection of 'living' certified deeds ready for use by the qadi in charge, the qimatr is evocative of the distinction between the Islamic approach to document use, and a proper judicial archive à l'Européenne; and this difference resided, ultimately, in diverging notions and ideas about validity. ${ }^{130}$

Another archival locus that deserves to be mentioned here is the Haram documents, a collection that was identified soon after its discovery as the archives of a judge active in Jerusalem in the fourteenth century. The discovery of a coherent series of judicial papers pushed the initial research team, led by Donald P. Little, to interpret the collection as proof that medieval Arabs regularly kept and stored their judicial archives. However, a successive generation of researchers of the Haram al-Sharif records has questioned the very idea that they represent a qadi archive. A convincing inquiry by Müller into the nature of the Jerusalem collection dealt a definitive blow to the idea that the survival of documents can be conflated with the existence of an Islamic archival tradition, and confirmed that the Ḥaram collection cannot be defined as an archive. ${ }^{131}$ Very forcefully, Müller

129 Hallaq, "The qādī's dīwān (sijill) before the Ottomans", 434.

130 Tillier, Mathieu: "Le statut et la conservation des archives judiciaires dans l'Orient abbasside (IIe/VIIIe-IVe/Xe siècle): un réexamen", in: L'autorité de l'écrit au moyen âge: orientoccident: XXXIXe congrès de la SHMESP, Le Caire, 30 avril-5 mai 2008, Edited by Publications de la Sorbonne,263-276, 2009, 5, Müller: "The Power of the Pen: Cadis and their Archives in Medieval Islam", 372.

131 Little, "The Significance of the Ḥaram Documents", Müller, "The Ḥaram al-Sharïf collection", 459 . 
demonstrated that the Jerusalem papers were not the result of a systematic effort to safeguard a series of records. Instead, they consist of an array of papers kept for the sole purpose of serving an ongoing investigation. The Haram collection was merely evidence in a trial against the judge in charge, Ibn Ghānim, for corruption, and included documents related to some cases passed before him during his tenure. This material related to old suits would have been discarded if it had not been for the investigation against Ibn Ghānim. Müller's demonstration is all the more important in that it undermines the views, most notably of Hallaq, that medieval judicial archives were kept and that Ottoman practice simply stemmed from Mamluk precedent. Despite this, most writers dealing with this issue continue to unquestioningly adopt the view that the Haram papers prove that judicial archives, comprising whole court proceedings, were kept. This tendency has been epitomized by a contribution by Bauden in 2013, in which he acknowledges Müller's conclusions, but pushes them down into the footnotes, despite the fact that the latter's analysis invalidates Bauden's own views that medieval archives actually existed. ${ }^{132}$

\subsubsection{The Sijill: from Scroll to Codex}

Another clue as to the evidentiary divide can be found in the new meanings that the Arabic word sijill acquired over time. It has traditionally been assumed to be of Latin origin (sigillum, or seal), and to have come to Arabic via Greek and Aramean variations. During the early middle ages, it was the word originally used for the physical attribute of Byzantine officials — the seal — that acquired the meaning of the physical support it was impressed upon-the scroll—and as a result began to signify a legal effect, such as a ruling or certification. ${ }^{133}$ It has been noted that Byzantine seals served the purpose of securing documents, as well as validating archival copies. The seal, moreover, was in itself an object of archival practices, and collections of seals have been discovered in Constantinople and Preslav. If we stick to this formal, artifact-based viewpoint, the medieval Islamic sijill was not perceived as a seal, as it was in classical antiquity, but as a document certified by that instrument. Ibn Iyās bitterly complaints that Sultan Qānșūh al-Ghawrī (ruled 1501-1516) neglected the

\footnotetext{
132 Bauden: "Du destin des archives en Islam", 29, n.9.

133 Little: "Sidjill", Encyclopaedia of Islam, Second Edition, Ix: 538b, Meshal, "The State, the Community and the Individual", 105-6. The etymology of sijill is further complicated by its proximity to the Aramaic word for 'clay', and therefore to the notion of seal, Robinson, Neal: "Clay", in: Encyclopaedia of the Qur'ān, edited by Jane Dammen McAuliffe, Brill, 2003, 1:339a, and Troupeau, Gérard: "Metals and Minerals", op. cit., 3:383a.
} 
affairs of the state and tended to procrastinate the signing of administrative edicts, to the point that Mamluk secretaries found themselves forced to buy "old sealings" to stick to the new decrees. ${ }^{134}$ Here, the word for sealing is 'alā$m a$, not sijill, signifying 'sealing' or the 'well-known motto' that was stamped by the judge onto legal documents to certify them. ${ }^{135}$ Rendered as sigilletto, or less frequently as cozetto (from Tr. hüccet, or notarial deed), in the jargon of Italian-speaking merchants in Ottoman lands, the term is often used in post1517 European sources.

In the debate on the existence of Islamic archives, one front has devoted its energy to questioning whether the Arabic term sijill refers to a body of documents, to the judge's archive, or to a physical register where his deeds were drawn up. Authors dealing with the medieval judiciary call the judge's collection the dīwān al-qāḍī, however Ottomanists prefer instead the Turkish word sicill, to refer to the qadi archives. If we hold uniquely to its formal definition, we learn that the Qur'ān clearly understands sijill to mean a scrollshaped record. It should be noted that both the Qur'ān and early traditions adopted a positive attitude towards scrolls as proof, as does the Revelation as regards written contracts. ${ }^{136}$ It may seem that medieval Muslims understood sijill to mean a certified, most probably scroll-shaped, legal document. Researchers dealing with Abbasid sources such as Aḥmad Ibn 'Umar al-Khașșâf (d. 874) read it to mean 'note of verdict' (enregistrement du jugement), a term that captures the legal nature of the concept, rather than its physical dimension, of which a copy was delivered to the plaintiff. ${ }^{137}$ Similarly and for Mamluk times, Müller arrives at the conclusion that the word signified 'certificate scroll,' and referred to the legal act that became the heading of a scroll-shaped document, followed by leaves containing successive certifications. Appending additional certifications to a given initial document is,

\footnotetext{
134 Ibn Iyās, Badā'ic al-Zuhūr, V, 92.

135 Müller: "The Power of the Pen: Cadis and their Archives in Medieval Islam", 374, 376, Johansen, "Signs as Evidence", 187, mentions the meaning acquired by the term in the semantic field of proof. al-Saḥmāwī, al-Thaghr al-bāsim, 375 .

136 Heck, Paul L.: "Scrolls", in: Encyclopaedia of the Qur'ān, 4:569b: Brill, 2003.

137 Tillier, Mathieu: "Le statut et la conservation des archives judiciaires", Müller: "The Power of the Pen: Cadis and their Archives in Medieval Islam", According to Müller "Early on, a siğill was a notification of a court decision that required the original witnesses to be questioned again by the new judge ... From the tenth century onwards, cadis' certificates (siğillāt) combined the use of notarial documents with the attestation of court proce-

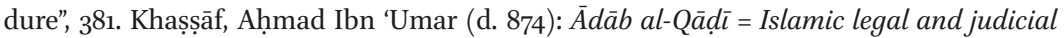
system, edited by 'Umar Ibn 'Abd al-'Azīz Șadr al-Shahīd and Munir Ahmad Mughal, New Delhi, Adam Publishers, 2017.
} 
incidentally, the most obvious way of adding such a (potentially unlimited) series of attachments.

Insisting on the continuity between medieval and modern documentary practices, Hallaq has maintained that before and during Ottoman times the sijill was a large ledger; a claim that has been contradicted by thorough examination of the Jerusalem collection by Müller, who showed that the Mamluk sijill was in fact a scroll. Because Hallaq did not attempt to provide any elements to support his views, he overlooked the term's changing meaning between medieval and modern times. The Ottoman sijill (sicil) took the form of a codex-that is, a collection of paper leaves bound together and forming a single unit. Indeed, upon closer inspection a clear transition can be identified between the 14th and the 16th centuries: in the words of Müller, in contrast with Mamluk practice the Ottoman court registers "were organized differently and taken together functioned as a siğill (certificate): written mostly in chronological order in a codex." In an article published in 2018, Müller explicitly sanctions the definitive transformation of the scribal artifact: "Mamluk archives with their scrolls stored in boxes were replaced by Ottoman sharía court records in the form of registered books." ${ }^{138}$ The material transition from scroll to codex implies a willingness to bind together groups of documents at a single time, hence creating the notion of court proceedings. Indeed, Müller notes that in Ottoman judicial ledgers the documents included under each entry of the register "were considered evidence" and did not need to be resubmitted for further certification. Cases could continue to be investigated under newly-appointed judges without the need for prior certification or additional isjāl procedures. The Ottoman court register, in sum, rendered obsolete the Mamluk sijill as a certification procedure and as a scribal artifact. Sicil, therefore, became equated with the judge's archives, under the form of ledgers; a physical artifact safeguarding validated court proceedings, but which also included the judge's activities as a notary.

It should be clear by now that a strong relationship existed between the idea of legal certification, and that of legal preservation, and that judicial documents functioned as simple aide-memoires. In the Ḥaram al-Sharif collection, different versions of the same act (such as inventories) can be found, containing small but important lexical differences; textual differences were of little importance, because the contents of these documents needed anyway to be orally confirmed by the witnesses, when needed, before the judge. ${ }^{139}$

\footnotetext{
138 Müller: "The Power of the Pen: Cadis and their Archives in Medieval Islam", 380.

139 Müller: "Ecrire pour établir Ia preuve orale en Islam: Ia pratique d'un tribunal à Jérusalem au XIVe siècle".
} 
Truth resided in the utterances pronounced by trustworthy Muslims, irrespective of written variations present in the aide-memoires that supported their testimonies. It is for this reason that Monica Gronke has rightly described the style of notarial deeds as cursory and often incomplete. ${ }^{140}$ She forgets, however, that in order for them to have been legally valid-before a judge, for example - the ritual of notarization required a reconstruction of the conditions in which the word had been transformed into writing. Significantly enough, a recent study of 150 notarial documents from Granada makes it clear that the deeds in the collection were simple aide-memoires to be corroborated in court, where the judge validated testimonies by writing shahida ("he testified") over their names. Signatures were often absent or illegible, and we can extend this same generalization concerning oral validation procedures to the case of 14th-century Jerusalem, as studied by Müller. ${ }^{141}$ Even in Latin Europe, notaries sought publicity in the drafting of their deeds. In his discussion of the performative and ceremonial aspects of the medieval notaries of Marseilles, Daniel L. Smail notes that the ceremony of notarization appears to have played a role in fixing events in memory: notarization, paradoxically, served the interests of memory. ${ }^{142}$ In medieval Islamic societies, records that for some reason needed to be kept valid, and that were therefore certified time and again, were preserved (first in the early qimațr, or later in the middle ages, in the qadi's perishable dīwān), while regular documents tended to lose validity over time and were destroyed. ${ }^{143}$ The perishability of documents was to change radically at some point in the early modern period, and it is in the practice of ledger record-keeping that this transformation found its most complete expression.

140 Gronke, Monika, “La rédaction des actes privés dans le monde musulman médiéval: théorie et pratique", Studia Islamica 59 (1984), 159-174.

141 Carro and Zomeño: "Identifying the "udūl in Fifteenth-Century Granada".

142 Smail, Daniel Lord: "Notaries, Courts and the legal Culture of Late Medieval Marseille", in: Urban and Rural Communities in Medieval France, Provence and Languedoc, 10oo1500, Edited by Kathryn Reyerson and John Victor Drendel, 23-51. Leiden-Boston: Brill, 1998, 49 .

143 For some authors acknowledging the preservation of archives and records for the early-modern period, Eddé, Anne-Marie: "Documents et archives d'Orient: conclusions provisoires et tendances de la recherche actuelle", in: L'autorité de l'écrit au Moyen Âge (Orient-Occident):XXXIXe Congrès de la SHMESP(Le Caire, 30 avril-5 mai 2008), Éditions de la Sorbonne, 385-40o. Paris, 20o9, Fadel, Mohammad: "al-Qadii", in: The Oxford Handbook of Islamic Law, edited by Rumee Ahmed and Anver M. Emon, 317-8. 


\subsection{Notaries in the Cross-Confessional Middle Ages}

Documents and the material artifacts that embodied them need to be understood not only in light of specific archival practices and surviving collections, but through a complex kaleidoscope of notions and beliefs about truth and evidence. Moreover, the logics of document production, use and preservation not only changed over time, but also differed from those followed in Latin Europe. In this section I turn to notarization, as the debate on archives has focused more often on the circumstances determining whether a document was preserved or not, than on its actual inception. I first underline the differences between the southern European, 'Latin,' notaries and their Islamic counterparts, as regards sources of legitimacy, notarial skills, and their respective institutional environments. To illustrate actual practice, I dedicate special attention to the Mamluk commercial cities before 1517, where both types of notarial culture coexisted, and to a certain degree, interacted. The cities of commerce such as Damascus, Aleppo or Mecca abound with references to local 'udūl operating in the streets and markets. Port-cities harboring Frankish vessels such as Alexandria held a special status (thughūr) as frontier zones, ${ }^{144}$ and hosted many notaries attached to the administration, such as those we encounter in the 1387 Florentine document discussed in section 2.1.2.

While Mamluk sources can be overly greedy in technical details, and often express themselves in an allusive tone, they contain abundant references to notaries. Harsh criticisms abounded, and this has led contemporary historians to hasten to describe the Mamluk judiciary as fundamentally corrupt. Ibn Ṭūlūn and al-Qudsī report sayings such as "all men are honest ('udūl) except the "udūl," and popular verses targeting the notaries as "a tribe brandishing the spears of false witnessing," labeling them as "sultans in the realm of sijills" and property deeds, who "shed blood through the nibs of their pens." 145 While authors such as al-Maqrīzi or Ibn Iyās (particularly the latter) considered the Mamluk judiciary to be far more versed in sharīa than the Ottoman conquerors, they also seem to admit that there was always a shāhid ready to testify when needed. However, it would be unfair to pretend that references to honest notaries did not also abound, most often in obituaries praising their religious qualities; indeed, one sign of their piety that was praised, and which might

144 Catlos, Brian A.: The victors and the vanquished: Christians and Muslims of Catalonia and Aragon, 1050-1300, New York: Cambridge University Press, 2004, 23-71.

145 Ibn Ṭūlūn, Shams al-Dīn Muhammad Ibn 'Alī (1485?-1546): Naqd al-țālib li-zaghal al-manāșib, edited by Muhammad Ahmad Dahman and Khalid Muhammad Dahman, Beyrouth, 1992, 88., al-Qudsī, Badhl al-nasāịh al-shar'iyya, 212. 
astonish the contemporary reader, was their insistence on keeping women and dhimmīs away from their stalls. It is difficult, though, not to note that the Muslim notary, precisely because of his prerogative as bearer of truth, found himself in a position of superiority, and often abused it. Despite this potential abuse of power, as regards their labor in bridging cross-confessional relations, notarial activity was fostered by Mamluk governance. By supporting the notarization of deals between Muslims and Franks, the sultan emphasized his protection over unbelievers engaged in trade and diplomacy, and thus fulfilled one of his religious duties as the head of the community. The arrival of the Ottomans and the general reorganization of notarial activities had, therefore, a twofold effect: on the one hand, ordinary subjects saw their access to rights facilitated through the drafting of hujjas and the availability of qadi courts, while foreign merchants' activities were now tightly governed by sharía courts and regulations. On the other, mixed transactions were now registered by the qadis, and consequently the traditional actors of notarization withdrew from the marketplace.

Acknowledging differences between Western and Islamic notarial systems has often led historians to assume that they constituted two opposite, conflicting legal systems which, rather than interact with each other, simply coexisted in a divided Mediterranean. In the previous section, I sketched out the transformation that artifacts and storage facilities underwent after 1517, even though actors of notarization have traditionally been described as representing a certain continuity. Latin notaries in particular have been portrayed as the natural heirs of Roman law, and the notarial deed as finding its universal, public validity on the same classic grounds. In contrast, Islamic notaries are presented as a separate genealogy, one that did not share the Roman confidence in trustworthy documents, and whose legal system, therefore, missed out on the "triumph of the written" experienced in Latin Europe. Although divergent notarial systems engendered different preservation logics, and are therefore at the very root of the archival divide, it would be misleading to assume that the genealogies for Latin and Muslim notaries evolved on entirely distinct, separate lines-an assumption that is often shared by historians of Islamic law. On the contrary, the idea that notarized documents were endowed with public faith, and therefore valid without the oral support of their authors, is a legal contingency that only appeared at a later stage. Indeed, historians dealing with late Roman, Byzantine law depict a notarial system that in many respects exhibits striking similarities with the drafting of documents by Islamic 'udūl.

When interpreting the uses of writing and documentation in crossconfessional environments, historians have stressed that a clear boundary 
existed between Western and Islamic traditions. According to a commonlyheld interpretation, in legal or diplomatic contexts the two normative systems simply coexisted, and the primary locus for interaction was the occasional acceptance of each other's proofs. Extraneous proofs, it has been argued, were only accepted on condition that the counterpart advanced proof that had been validated according to his own evidentiary rules. This line of reasoning conveys a cross-cultural approach, assuming fundamentally separated notions of cultures and identities and, as we shall see, largely obscures the legal relations and interactions that actually took place. I argue instead that late medieval Mediterranean markets and courts witnessed the coexistence of two complementary notarial systems within a shared legal space. Multiple scribal institutions were known to merchants and other legal actors, who possessed a finely-honed understanding of these differences, and acted accordingly. While under the Mamluks mixed transactions were underpinned by different scribal institutions, a fundamental transformation was brought about by Ottoman legal reform, which meant that the registration of legal transactions suddenly looked very different after the Middle ages.

\subsubsection{Mediterranean Notarial Traditions}

The word shāhid signifies both a professional notary, and any "righteous witness" (shāhid 'adl) in a given community. Ideally, any believer of good reputation could notarize, provided he opened shop at the market and was recognized by a local judge. ${ }^{146}$ According to classical Islamic jurisprudence, only upstanding male Muslims were allowed to give testimony, and in time some of these witnesses came to perform professional notarial services. Since early Islamic times, the need to rely on a list of available trustworthy Muslims who could attest at court sessions favored registration at the mahkama, in order to differentiate them from occasional witnesses to facts. Claude Cahen has acknowledged, however, that this distinction between ordinary and professional witnesses was of a purely practical nature, and had little significance in the early days of Islam. ${ }^{147}$

In Ottoman times, instrumental witnesses (designated as shuhūd al-hâal) worked as court staff, where they attested to the authenticity of all legal documents and their incorporation into the sijill. They were also scribes, and often

146 The classic account is still Tyan, Le notariat et le régime de la preuve par écrit dans la pratique du droit musulman, 18-21, Tyan, Histoire de l'organisation judiciaire en pays d'Islam, I, 349-372, Wakin, Jeanette A.: The function of documents in Islamic law: the chapters on sales

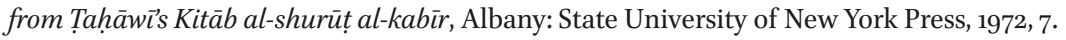
Cahen, Claude, "A propos des Shuhud", Studia Islamica 31 (1970), 71-79. 
drafted the contracts that were later to be notarized by the qadi. ${ }^{148}$ As has been mentioned, the recognition that the Ottomans gave to the instrumental witnesses came at the expense of the 'udūl, and by the 16th century the most notarial functions of the medieval 'udūl were being transferred to the Ottoman judge and his court staff. This fact has moved authors such as Reem Meshal to regard the functions of court notaries as "no longer having a private function," and to note a general shift "from local notarial class to Ottoman-trained clerks." ${ }^{149}$ In medieval times, in contrast, it was sufficient to obtain recognition from a qadi and to display competence in Islamic law in order to be counted as a reliable witness. However, in practice social conventions biased access to the notarial profession; we know that in cities such as medieval Aleppo, for example, the 'udūl were often chosen from among a pool of families considered to be endowed with a collective reputation of trustworthiness. ${ }^{150}$ Although respected notaries counted among professional religious scholars, Mamluk authors make it clear that other members of the religious learned community, often including merchants, could also practice the notarial profession on a temporary basis.

While any upstanding member of the community could act as a notary in Islamic society, in southern Europe notaries were instead public officers invested by the legitimate powers. These were the Pope, the Emperor, or his delegates. Only they could create the law, and therefore only they could delegate this creative power to the tabelliones - the Roman clerks charged with drafting private deeds. This stands in marked contrast with the realm of Islam, where God enjoyed the monopoly on lawmaking, and therefore the notary's legitimacy resided in his righteousness, and not on any given status. ${ }^{151}$ In practice, in the lands under theoretical imperial jurisdiction, feudal lords such as the

148 Fitzgerald, Ottoman methods of conquest, 109-13. Wilkins, Charles L.: "Witnesses and Testimony in the Courts of Seventeenth-Century Ottoman Aleppo", in: Lire et écrire l'histoire ottomane, Edited by Vanessa Guéno and Stefan Knost, Beirut and Damascus: IF POOrient-Institut Beirut, 2015, 107-129. Wilkins describes them as signatory or "notarial witnesses," in contrast with eyewitnesses and informants summoned before the judge. A most useful description of the shuhüd al-hāl is provided by Baldwin, Islamic Law and Empire in Ottoman Cairo, ${ }_{36}{ }^{-} 37$.

149 Meshal, "The State, the Community and the Individual", 118.

150 Ḥamzah, Niyābat Halab fì Așr Salāțīn al-Mamālīk (1250-1517 M/648-923 H), 254-5.

151 Cook, Michael: "Early Medieval Christian and Muslim Attitudes to Pagan Law: A Comparison", in: Islam and Its Past: Jahiliyya, Late Antiquity, and the Qur'an, edited by Carol Bakhos and Michael Cook. Oxford: Oxford University Press, 2017. Medieval issues revolving around notarization, the value of the written and witnessing are discussed by Madero, Marta, "Façons de croire. Les témoins et le juge dans l'œuvre juridique d'Alphonse X le Sage, roi de Castille”, Annales. Histoire, Sciences Sociales (1999), 197-218. 
Count palatine of medieval Genoa took over their social superiors' right to appoint notaries. ${ }^{152}$ Southern European city-states sought to impose controls on a candidate's knowledge of jurisprudence, and the latter were required to pass exams. In places such as Venice, measures to control access to the profession increased throughout the Middle Ages, and culminated in the early sixteenth century, when quotas were established. ${ }^{153}$ Islamic legal practice tended instead to keep a close watch on witnesses' morality, rather than on their effective legal knowledge, and judges were charged with monitoring the 'udūl's rectitude. In exchange, the notaries of a given qadi were permitted to sit around him at court hearings, according to precedence, and wearing a particular kerchief. ${ }^{154}$ Al-Maqrīzì describes a large-scale inspection of notaries and their workshops by judicial authorities, in order to ascertain the reputation of every single scribe. ${ }^{155}$ This is also reflected in the role of the purifier (muzakkī) described by legal historians, a court clerk entrusted with the task of verifying the moral credentials of witnesses and who, on occasion, could conduct investigations in local neighborhoods to ascertain the probity of individuals. Emile Tyan has described the efforts by eighth and ninth-century Egyptian qadis to cope with the problem of witnessing, first by drafting a list of authorized witnesses, then by implementing the institution of the muzakki, measures often contested by the population. Eventually, in the late Middle Ages the muzakki was replaced by a mechanism whereby candidates were elected into the body of 'udūl by their peers. ${ }^{156}$ Shari'a-based notarization, apart from the fact that it played a role in the conduct of administrative business, was required in ample areas of daily life. Witnessing was needed in matters ranging from the grinding of harvest crops to the announcement of the official start of the lunar months. Religious festivities, for example, had to be determined by eye-witnessing of the phases of the moon. Ibn Tuulūn reports an episode in which a group of ulama refused to take part in the festivities at the end of Ramadian because, they argued, the witnesses attesting to the beginning of the month "were not upright."157

\footnotetext{
152 Airaldi, Gabriella: Studie documenti su Genova e l'oltremare, Genova: Università di Genova, 1974, 197-241.

153 Pedani, Maria: Veneta auctoritate notarius: storia del notariato veneziano: 1514-1797, Milano: Giuffrè, 1996, Airaldi, Studi e documenti su Genova e l'oltremare, 227.

154 Ibn al-Ḥanbalī, Muḥammad Ibn Ibrāhīm al-Ḥalabī (1502 or 3-1563): Durr al-habab fi tarikh a’yan Halab, edited by Mahmud Fakhuri and Yahya Abbarah, Damascus: Wizārat alThaqāfah, 1972-1974, I, 3 o and n. 3.

155 al-Maqrīzī, Aḥmad Ibn 'Alī (1364-1442): Kitāb al-sulūk li-ma'rifat duwal al-mulūk, edited by Said A. F. 'Ashour, Cairo: Matba'at Dar-al-Kutub, 1970-1973 III/2, 933.

156 Tyan, Histoire de l'organisation judiciaire en pays d'Islam, I, 357.

157 Ibn Ṭūūn, Mufākahat al-Khillān, 412.
} 
There were not only formal differences between the Venetian clerks and their Islamic counterparts; Latin notaries were able to produce written documents endowed with legal value in court (empowered with public fides), while Islamic notarial deeds were not valid without the oral support of their authors. ${ }^{158}$ An Islamic document was not considered primary evidence until the witnesses and the notary who had drafted it had appeared in the courtroom and certified both the document and its contents. The Franks involved in trade in Mamluk lands describe the 'udūl, therefore, as "witnesses who wrote."159 They invariably used the term testimoni to refer to the 'udūl and to notarial deeds, but never for the regular scribes, often of Christian origin, who were employed in the customs houses and in the personal dīwāns of prominent merchants.

In the late Middle Ages, southern European cities witnessed the emergence of the professional notary. By this period, most Italian city-states had come to rely heavily on a new category of notary empowered with official authority, who drafted "public" notarial deeds, and not just private acts, and it is generally agreed that it is around this time that the notarial act acquired juridical value. ${ }^{160}$ The genuine nature of a contract came to depend on the officer's signature, rather than on the presence of witnesses. Notaries were incorporated into chanceries, courts of justice and communal administrations, such as the consulates in Alexandria and Damascus, where Venetian clerks became regular figures. They offered their services to the whole Frankish community, which, particularly for matters of debt, could benefit from the validity of notarial acts in their own city's courts. ${ }^{161}$ As a result, deeds drawn up in Alexandria

${ }_{158}$ For the use of deeds in other mixed, southern European contexts, see Burns, Robert Ignatius: Jews in the notarial culture: Latinate wills in Mediterranean Spain, 1250-1350, Berkeley: University of California Press, 1996, 32-51, McKee, Sally: Uncommon dominion: Venetian Crete and the Myth of Ethnic Purity, Philadelphia: University of Pennsylvania Press, 2000, 19-57, Smail, Daniel Lord: The consumption of justice: emotions, publicity, and legal culture in Marseille, 1264-1423, Ithaca: Cornell University Press, 2003 and his influential chapter: "Notaries, Courts and the legal Culture of Late Medieval Marseille".

159 ASVe, CI, N, B. 222, Notary A. Vactaciis, f. 43r-v, undated (March 5-9, 1401): "Item soluit testibus saracenis a gabano qui scripserunt, f.108r-v, Dec. 22, 1405: in testificatione testium saracenorum." Examples of this can be multiplied, with numerous mentions in the accounts of the Foscari firm in Alexandria, whose staff records the sums paid for notarial sevices at the customs: "per testimonio de doana per so chortexia", ASVe, Procuratori di San Marco, Misti, XXIX, B. 44A, Accounts Antonio Coppo 1481, f.2r.

160 Costamagna, Giorgio: Il notaio a Genova tra prestigio e potere, Roma: Consiglio nazionale del notariato, 1970, 7-32.

161 Most noteworthy among the profuse Italian scholarship on notaries, are the monographs on Genoa (ed. G. Costamagna) and Venice (M. P. Pedani) in the Studi storici sul notariato italiano series, together with several conference proceedings edited by V. Piergiovanni, 
and Damascus found their way into trial proceedings held elsewhere. Before a Genoese court of justice in Famagusta, for example, a Damascene deed dated 1447 by the Venetian clerk Andrea Michiel was produced as proof by one of the litigants. ${ }^{162}$ Many of the notarial deeds drawn up by these outremer notaries describe issues that ended up before Islamic judges. When they were brought before the qadis, Frankish merchants generally asked for an official record of proceedings, in order to be able to report back to Europe, and this is why they described their experiences with local justice to their Latin notaries.

The most striking divergences between Western and Islamic notarial traditions can be observed in the probative status of the written deed, and the very different approaches to its preservation. Venetian notaries kept a detailed copy of the deeds that needed to be preserved in state archives. Indeed, the Venetian authorities put great emphasis on the preservation of registers in the state archives, and issued regulations to that effect. According to Venetian regulations, outremer notaries were expected to draft their deeds in codex-shaped, paper protocols. ${ }^{163}$ Venetians were equally invested in the safeguarding of the notarial and administrative collections of lost colonies, such as Crete after it fell into Ottoman hands in $1669 .{ }^{164}$ In contrast, 'udūl records were valid only during the lifetime of their authors, and in most cases there was no need to preserve them afterwards. Somewhat like Byzantine tabelliones, Islamic notaries do not seem to have preserved notarial acts en minute, a fact that Frankish traders found abhorrent. These differences demonstrate that both notarial systems, if they were not necessarily in conflict with each other, exhibited alternative and complementary features, which ultimately accounted for the medieval presence of Latin notaries in the Islamic cities of commerce-a presence that, not surprisingly, ended with the Ottoman takeover of the Arab provinces.

such as a recent one devoted to notarial public faith: Piergiovanni, Vito.: Hinc publica fides. Il notaio e l'amministrazione della giustizia, Milan: A. Giuffrè, 20o6. On the Roman period, see Amelotti, Mario: "Fides, fides publica in età romana", in: Hinc publica fides. Il notaio e l'amministrazione della giustizia, Edited by V. Piergiovanni, 9-2o. Milan: A. Giuffrè, 2006. On the validity of notarial documents as juridical items "in court and outside," see Burns, Jews in the notarial culture, 38-43, Pratesi, Alessandro: Genesi e forme del documento medievale, Roma: Jouvence, 1979, 47-55, and, for Genoa and Venice, Bartoli Langeli, Attilio: Notai: scrivere documenti nell'Italia medievale, Roma: Viella, 2006, 59-87, where an exhaustive bibliography is provided.

162 ASG, SG 590/1289, f.106v.

163 Bigaglia, Marco. A.: Capitulare legum notariis publicis Venetiarum, Venice: Apud Andream Poleti, 1689, 16, 24-27, Wheeler, Joseph Russell, "The sestiere of San Polo: a cross section of Venetian society in the second half of the fifteenth century. PhD thesis, University of Warwick", (1995), 12-14.

164 McKee, Uncommon dominion: Venetian Crete and the Myth of Ethnic Purity, viii. 
More importantly for my argument, these differences between Western and Islamic notarial systems motivated a promiscuous recourse to notarial institutions by merchants. A series of documents from the notarial collections of Genoa are most illuminating in this regard. In two deeds drawn up in Genoa in 1475 and 1479 by the notary Emanuele Granello, a merchant summoned witnesses to prove the losses he incurred while he was a resident in Algeria. According to the witnesses, this Genoese merchant, Urbano de Dernisio, was living in Béjaïa in 1475, where, as reflected by both Islamic and Latin deeds, the Catalans Benet Spital and Joan Sala owed him money. Together with an accomplice named Venturino, himself a debtor, Spital broke into the house of his Genoese creditor and stole a few golden objects, some merchandise, together with Dernisio's book of accounts, as well as "diversas alias scripturas, tam in arabico quam in latino scriptas." Spital tore and burnt the Islamic deeds mentioning his debts for a total amount of 672 golden dinars. As a result, the Genoese merchant was left with no means to prove his debts. As Dernisio himself bitterly argued, "Muslim notaries do not preserve authentic copies of the deeds they draw up," and in a second deed related to the same facts he added "they do not keep registers."165 In other words, according to Dernisio the 'udūl neither kept originals, nor did they preserve them in codex-shaped artifacts for future reference. This may have been the norm for private contracts, even though, as suggested by the Florentine enquiry, some legal transactions subject to taxation by the Mamluk courtiers (Ar. simsār), such as sales contracts, necessarily left some documentary trace behind them. Destroying Dernisio's contracts may well have been useless under Islamic jurisdiction, since jurisprudence allowed witnesses to give testimony for debts and similar legal actions in case papers went missing, because they entailed effective rights. ${ }^{166}$ The

165 "dictus Venturinus simul cum Benedicto Spitale barchinoniensi furtive acceperunt de scriptorio domus habitacionis dicti urbani in dicto loco buzee diversa cartularia rationis dicti urbani et diversas alias scripturas scriptas tam in arabico quam in latino inter quas erant dicta dua instrumenta scripta in arabico unum videlicet per quod constabat Benedictum Spital et Johannem Sala barchinionienses dare debere dicto urbano duplas 600 buzee et aliud sicut dictus benedictus erat debitor dicti urbani de duplas 72 et uno quarto buzee. Que instrumenta dictus venturinus tradidit dicto benedicto qui ea laceravit et combusit. Quas duplas 672 et quartum unum dictus urbanus exigere non potuit a dictis benedicto et johani. eo quia non habebat dicta duo instrumenta ut supra capta furtive per dictos Benedictum et Venturinum, et quia notarii barbari non tenent registrum instrumentorum per ipsos conpositorum", ASG, Notai Antichi, 871, doc. 274. With small lexical variations, the episode is also described in doc. 296: "mauri non tenent autenticum instrumentorum per ipsos conpositorum".

166 Johansen, "Formes de langage", 350, notes that this was not the case for documents not engendering effective rights, such as court proceedings. 
creditors were much more likely, however, to have been targeting Dernisio's options for recourse back in Latin Europe, where he would not be able to substantiate his claims. In these documents, Dernisio was instructing the notary about the two divergent notarial systems, and this legal argument was indeed crucial to his case, because it helped to explain his inability to prove his Spital's debts with documentary proof. Dernisio's argument clearly refers to the Islamic notarial system in general (here referred to as notari mauri, notari barbari), and goes far beyond a more narrow reading that "the keeping of minutes ... did not exist in Béjaïa."167

Abd al-Rahmān Ibn 'Umar al-Jawbarī (died after 1222) counts notaries among the Damascene low life he describes in his al-mukhtārfı kashf al-asrār, a work devoted to the adventures of swindlers, alchemists, beggars and thieves. According to al-Jawbarī, the 'udūl cooked the deeds by introducing ambiguous wording and formal errors, allowing one of the parties to have the transaction invalidated. He suggests that clients often repented and that, with the help of the 'udūl, the parties knew that notarized transactions could be contested and businesses, eventually, overturned. More interestingly, the murky status of Islamic documents made witnesses to the deed easy to manipulate. A hujja sanctioning either unimportant or well-known facts, such as small debts or transactions related to deceased clients, could be erased and a new deed forged. In the new hujja, the original witnesses' signatures were reused, who, in that case, would never be able to deny the validity of the new document's contents (lā yankarūn al-shuhūd khuțūtahum). ${ }^{168}$ If uncorroborated Islamic deeds could hardly prove anything before a qadi, paradoxically, Dernisio or al-Jawbarīs stories suggest that corrupted of absent hujjas seriously compromised the witnesses' commitment to the truth, and led to the loss of rights.

\subsubsection{Legal Fiction and Roman Ancestry}

The traditional narrative on the genealogy of the notarial system sees late medieval notaries as heirs of the Roman past. Often associated with chanceries and administrations, southern European communal cities witnessed the

167 "la pratique du minutier [...], n'existait donc pas à Bougie", Valérian, Dominique: "Le recours à l'écrit dans les pratiques marchandes en contexte interculturel. Les contrats de commerce entre chrétiens et musulmans en Méditerranée", in: L'autorité de l'écrit au moyen âge: orient-occident: XXXIXe congrès de la SHMESP, Le Caire, 30 avril-5 mai 2008, Publications de la Sorbonne, 2009, 59-73.

168 al-Jawbarī, 'Abd al-Raḥmān Ibn 'Umar: Al-Ǧawbarī und sein Kašf al-asrār: ein Sittenbild des Gauners im arabisch-islamischen Mittelalter (7./13. Jahrhundert): Einführung, Edition und Kommentar, edited by Manuela Höglmeier, Berlin: Klaus Schwarz, 2006, 306. 
ascension of notaries able to draft deeds that were vested with universal validity. Unlike the 'udūl, whose authority relied on religious legitimization, Latin notaries claimed it for themselves thanks to investiture by spiritual or temporal powers. Even in late medieval times, when the Holy Roman Empire was a political fiction, notaries were appointed by feudal lords claiming some imperial legitimacy. ${ }^{169}$ In practical terms, this implied that their deeds' legitimacy extended throughout the Holy Roman Empire, and included the portion of the Mediterranean now under Muslim rule. ${ }^{170}$ As a universal ruler, the Emperor guaranteed universal validity for their deeds, which were valid ubique terrarum, anywhere on earth. ${ }^{171}$ Historians often assume that a direct link exists between the Roman notaries, or tabelliones, and the medieval Latin notarial institution, seeing it as part of a revival of classical Roman Law, a legal system sensitive to written proof. Under this system, it was natural that such documents, issued by clerks vested with legitimate authority, be valid without necessitating the support of oral witnessing. Public faith, therefore, went hand-in-hand with the notary's imperial investiture. This narrative naturally leads us to the idea that Western notaries were 'Roman' in origin, and Muslim notaries 'Islamic.' In my view, however, such an assumption is problematic for several reasons.

Roman documents were endowed with public faith and were actually kept in some kind of state archive, but this was the prerogative of public documents produced by a government official. However, the Roman tabellio limited himself to drafting private deeds; although they bound both parties, such deeds did not constitute firsthand and definitive proof in court, even if they were drawn up in the presence of witnesses (publice confectum), and included some additional assurances (such as the notary's completio). Indeed, there are descriptions of Roman and Byzantine notaries receiving clients in

169 Airaldi, Studi e documenti su Genova e l'oltremare, 199.

170 "Mais l'institution notariale avait un caractère international; l'acte public fait autorité dans toute la Chrétienté", Richard, Jean: "Aspects du Notariat public à Chypre sous les Lusignan", in: Diplomatics in the Eastern Mediterranean 1000-1500: Aspects of CrossCultural Communication, edited by Alexander D. Beihammer, Maria G. Parani, et al.: Brill, 2008, 207-222, 220. Airaldi, Studi e documenti su Genova e l'oltremare, 209, Airaldi, elaborating on the investiture of an outremer notary dating from 1454, notes that jurisdiction extends "per omnes terras et loca que Romanum profitentur Imperium". On universal validity, "la facoltà di nomina dei notai è valida in qualunque sito essi si trovino, anche nel Levante, purché in esso viga il diritto del Sacrum Romanum Imperium", 228-29. See also Murray, James M.: Notarial instruments in Flanders between 1280 and 1452, Bruxelles Académie royale de Belgique, 1995, 11.

171 This formula is often used by the imperial notary in Cyprus; Nicola de Boateriis Nicola de Boateriis notaio in Famagosta e Venezia (1355-1365), edited by Antonio Lombardo, Venezia: Comitato per la pubblicazione delle fonti relative alla storia di Venezia, 1973. 
their workshops (stationes), and this offers a striking parallel with the stalls (marākiz, hawānīt) that hosted Islamic notaries in the streets of medieval Syria and Egypt. As concerns public faith, in a recent monograph on early modern Roman notaries, Laurie Nussdorfer suggests that endowing notaries with $p u$ blica fides was a medieval invention by Italian commentators, something that came in handy in the construction of the Ius Commune. ${ }^{172}$ Studies on early notarial practice show that at some point scribes started to reclaim imperial/ universal authority and validity for their deeds, with no apparent precedent. Marta Madero has contributed to further elaborating this picture by reminding us that medieval jurists were perfectly aware that believing documents over witnessing was a legal fiction, and a necessary 'mirage.' Innocent IV, in a famous passage of the Apparatus in quinque libros Decretalium (II, 22, 15, ca. 1245) establishes a necessary link between the problem of ensuring legitimate investiture for the notary, and the validity of the written document. Notaries could only be instated by Emperors and Popes, as the latter were the only valid sources of law who could delegate such power to a third party. Delegating this power implied acknowledging the capacity of notaries to legitimize a legal fiction, by giving validity to signs "written on a dead animal's skin."173

The probative nature of artifacts, the role of medieval notaries, and issues of jurisdiction were indeed interrelated. Much can be gained, therefore, in seeing the attribution of public faith to notarial deeds, not as a direct appropriation from the classical past, but rather as the result of a process that was evolving throughout medieval times. By disrupting the alleged linearity of notarial genealogies, historians of Roman law have detected a willingness by successive emperors to endow written documents with probative value, until the reigns of Valentinian and Valens (ruled 364-375). ${ }^{174}$ The opposite tendency, to mistrust written proof and to enhance the value of oral witnessing, surfaced shortly after this period, and reached its peak under Justinian (ruled 527-565). A similar hiatus can be found in Justinian codes, forbidding Jews from testifying against Christians, hence diverging from classical precedent, when religion had not been an issue, and indeed converging with sharīa practice. ${ }^{175}$ It is possible that

172 Nussdorfer, Laurie: Brokers of Public Trust:Notaries in Early Modern Rome, Baltimore:Johns Hopkins University Press, 2009, 9.

173 Madero, "Façons de croire. Les témoins et le juge dans l'œuvre juridique d'Alphonse X le Sage, roi de Castille", 202.

174 Ankum, Hans A., "Les tabellions romains, ancêtres directs des notaires modernes", Atlas du Notariat. Le Notariat dans le Monde. Huit Siècles de Notariat Latin, Ars notariatus, 42, Amsterdam: Kluwer, 1989, 5-44, 15-6.

175 Fattal, Antoine: Le statut légal des non-musulmans en pays d'Islam, Beyrouth: Imprimerie Catholique, 1958, 361-64. 
late Roman law adopted a different attitude, that might well be connected with the Islamic biases against the written and against unbelief; this is all the more striking when we consider that, as noted earlier, the Qurān has a positive attitude towards contracts and writing, and does not expressly ban non-Muslim witnesses. The biases, it has been noted, stemmed from Middle Eastern legal practice in Umayyad times, not from scriptural injunctions. The "triumph of the written," and of public faith in the West, was therefore a late medieval, contingent development. In Genoa, use of the private deed without recourse to witnesses emerged in parallel with the emergence of notaries endowed with a "stronger fides" towards the end of the 12th century, who signed not just as "notarius," but also claimed imperial nomination (notarius sacri imperii, sacri palacii). ${ }^{176}$ In his research into Ravenna's notaries, Mark Steinhoff sees this coincidence between universal authority and public faith in notarial texts as coming about shortly earlier, around 1050. He quotes a text, dated 1033, equating publica with imperial authority, as the earliest manifestation of what would become the norm in subsequent centuries. ${ }^{177}$

Research on Justinian's law offers some additional parallels between Byzantine and Islamic notaries. According to descriptions in Justinian's Novels 44 and 73 , the logic of production, use and validation of documents followed by Byzantine notaries was identical to that of their Islamic successors. As was the case for Muslim notaries, minutes were not kept by the former, and both notaries and witnesses had to be summoned to court to prove the authenticity of a given document. Witnesses to private deeds were expected to attest to the veracity of transactions, and in the eventuality that they passed away, judges proceeded by comparing samples of their handwriting with that in the deed (comparatio litterarum) —although Justinian's law mistrusted this procedure. ${ }^{178}$ Both Justinian's law and sharīa mistrusted the holographic will—an issue that was later contested in Siyāsa works of the Mamluk period, which called for freer recourse to written evidence, first by Ibn Taymìyah, and later by his disciple Ibn Qayyim al-Jawziyya. Similarly to the Muslim 'udūl,

176 Rovere, Antonella, "I "publici testes" e la prassi documentale genovese (secc. XII-XIII)", Serta antiqua et mediaevalia I (1997), 291-332, 325-6, Costamagna, Il notaio a Genova tra prestigio e potere, $55^{-6}$.

177 "This moment in history, circa 1050, is a critical point in the evolution of the authentic act; notarial acts acquired publica fides at the same time as the idea that notaries should be appointed by some universal authority, either imperial or papal, took hold". Steinhoff, Mark Wayne: Origins and Development of the Notariate at Ravenna (Sixth through Thirteenth Centuries), Thesis (Ph. D.), New York University: Ann Arbor, Mich.: University Microfilms International, 1976, 74.

178 Lévy, Jean-Philippe: Autour de la preuve dans les droits de l'antiquité, Naples: Jovene, 1992, 155-75, Amelotti: "Fides, fides publica in età romana". 
the Byzantine tabellio conferred in the statio with his client, acquiring firsthand knowledge of the business at hand, so that he could later testify to its veracity in court, even when the effective drafting of the deed was entrusted to an assistant. It is clear from this parallel that what both notaries were producing were private deeds serving as aide-mémoire, and that such documents required additional certification by those who participated in their redaction. At least under Islamic law, authentic documents were neither kept nor collected. In contrast, the use of protocols in Byzantine notarial practice has been noted; however, according to Novella 44 the Byzantine protocol should be understood, not as the Ottoman bound ledger guaranteeing that originals were collected, but as a kind of official stamped paper covering the initial part of the deed. This first sheet of the document contained the name of the Count of the Imperial Exchequer, and hence served the purposes of validating the document's existence, rather than ensuring its preservation as an archival artifact. ${ }^{179}$ Nothing similar to an actual notarial protocol has survived from Islamic lands. Although we do have compilations of notarial formularies, they were most probably used as handbooks for notarial trainees, and owe their survival to their role as specimens, rather than to their legal validity, or even as aide-mémoires for future reference. Lastly, as can be inferred from the Nessana papyruses produced by hellenized Arabs shortly after the rise of Islam, it was the client, not the notary, who was credited with the deed's absolutio. This "oriental custom" held that it was the client who actually delivered the notarized document to the other party, while the notary simply limited himself to its drafting and to bearing witness to its validity. ${ }^{180}$

Apart from highlighting the continuity between late Roman and Islamic notaries, comparing the two traditions' understanding of the notarial function also helps us to question a deeper assumption: that Romans and Byzantines had public notaries at all. As we have seen, the tabelliones emerged first and foremost as clerks who drafted private deeds with no real public character, they were not initially public servants appointed by state authorities,

179 Amelotti: "Fides, fides publica in età romana", 17. Ankum, "Les tabellions romains, ancêtres directs des notaires modernes", 42, "We add hereto, that notaries shall not make the final draft of a document on any paper other than that which has in front what is called a protocoll, containing the name of the officiating glorious Count of the Imperial Exchequer, the time when the document was drawn and other things usually contained thereon; nor shall the protocoll be cut off, but bound with the paper; for we know that many documents written on such papers have in the past been and are now being proven to have been forged," See Novella 44, c. 2, The Codex of Justinian: a new annotated translation, with parallel Latin and Greek text based on a translation by Justice Fred H. Blume, 3 vols., Cambridge: Cambridge University Press, 2016.

180 Ankum, "Les tabellions romains, ancêtres directs des notaires modernes", 25. 
and they kept no minutes/originals. ${ }^{181}$ What would arise later as a distinctly Western Christian, or Latin attribute, is the public character of documents, not the Roman ancestry of the notarial institution. In addition, mistrust for written evidence is neither a necessary nor a specifically 'Islamic' approach to proof, and indeed this idea was most probably imported by early Islamic jurisprudence from their Byzantine imperial predecessors. Holding a blackand-white, essentialist vision of two opposing notarial systems is therefore to forget that both were directly, if unequally, rooted in antiquity, and moreover leads us into the error of conceiving of the 'Western' notariate as a direct heir of classical Roman law.

\subsection{The Case of the Outremer Notaries}

Towards the mid-fourteenth century, the Venetian state began to send notaries to Alexandria and Damascus, most probably as a result of the restoration of the galley convoys to the Levant in 1344, following the end of papal bans on trade with the infidels. ${ }^{182}$ The latter were imperial notaries, enjoying imperial jurisdiction, and hence should be distinguished from the common public notaries acting under Venetian Law (more veneto). The imperial notaries were recruited and trained differently, and were assigned to Venetian mainland possessions, which unlike the city of Venice were under imperial jurisdiction. Venice's state archives host a healthy collection of deeds drawn up in Alexandria or in Damascus by imperial notaries for the fist half of the $15^{\text {th }}$ century, and even some from the second half of the 14th century. There is however a dramatic decrease in deeds for the subsequent century; due to a fire in 1577, most documents for the period 1450-1517 have been lost, and it would appear that after that date, the Venetian government ceased to send notaries to the Levant for the rest of the 16th century. No extant protocols, even fragmentary, have survived for Syria or Egypt under Ottoman domination; I have come across two isolated references to notaries active for that period, but they seem to have worked exclusively as consular chancellors, and not as public notaries, most probably because the

181 "trois différences entre les tabelliones du droit de Justinien et les notaires modernes sont frappantes. Ces tabelliones n'étaient pas comme les notaires modernes des fonctionnaires publics nommés par les autorités de l'Etat; leurs actes n'etaient pas des actes authentiques (ils n'avaient pas de fides publica) et, enfin, ils ne conservaient pas de minutes.", ibid., 44.

182 Lane, Frederic Chapin: "The Venetian Galleys to Alexandria, 1344", in: Wirtschaftskräfte und Wirtschaftswege. I: Mittelmeer und Kontinent: Festschrift für Hermann Kellenbenz, edited by Jürgen Schneider, Stuttgart, 1978, 431-440. 
task had by then fallen under the qadi's prerogative. ${ }^{183}$ Genoese and Venetian notaries traditionally operated in the Black Sea, in Lesser Armenia and in the Byzantine territories, and in the Arabic-speaking échelles du Levant they met the 'udūl for almost two centuries.

For the period between 1350 and 1500, Damascus and Alexandria saw Venetian notaries and 'udūl crossing paths in the souks in search of clients, and thus the encounter between the two notarial traditions. In contrast, no Frankish notaries seem to have been dispatched to Mamluk Aleppo, a major city of commerce, despite the presence of consular institutions. By the same token, but for a vague isolated reference to them, no Genoese notaries appear to have operated in the Mamluk territories. This unique configuration, it seems to me, points to the conventional nature of notarial markets, with cities marked by the presence of a Venetian or a Genoese notary, but rarely both at the same time. In the Maghreb, Genoese clerks predominated, whilst Syria and Egypt were covered by the Venetian notaries. Indeed, Mamluk markets and courts looked different from those in Ottoman times because, after 1517, the Latin notary is missing from the picture, a fact that has received strikingly little attention. We have good coverage for Alexandria and Damascus, with notaries resident for two-year periods spanning from the 139os to the 145os, and then scattered deeds and testament collections for the rest of the Mamluk period; for the Ottoman period, however, the coexistence of notarial institutions, if it existed at all, has left no Latin traces.

Parallel to the Italian republics, in Mamluk times the notarial profession grew considerably, and commercial cities are in particular described as burgeoning with workshops in the markets, at the city gates and in the mosques. Indeed, the Mamluks saw the adoption of written contracts between Muslims and Franks as a first step towards building a framework for interfaith conflict resolution, and by the end of the Middle Ages Mamluk treaties signed with Franks began including new provisions that the 'udūl systematically notarize all mixed transactions. While 13th-century treaties accepted transactions either in or out of customs (in dogana ... extra dogana), notarized by witnesses or not (cum testibus ... sine testibus), the tendency in the fifteenth century was to require that all mixed transactions be notarized before Islamic 'udūl

183 ASVe Cancelleria Inferiore, Micellanea 2, Notary Claudio Giovanni, with a single deed in favor of the abbot of Saint Catherine, dated September 1567, and Iacopo Vigulo who drafted Marco Priuli's testament discussed in Chapter Four. The Bailo's chancery has yielded extensive series of notarial records preserved in ASVe Bailo di Costantinopoli series. 
and, where available, that sales be concluded within the customs facilities. ${ }^{184}$ By 1400, notarial witnesses were attached to several of the different customs departments—such as the Duchela and the Dīwān al-Qabbān, which are mentioned in the Florentine report of 1387 - and this was part of a general trend extending to other administrative and judiciary offices. ${ }^{185}$

How, then, did merchants decide which of two potential legal institutions to use-Venetian or Mamluk? Although it may seem fairly obvious that Latin clients would have chosen Venetian notaries - where they could find legal, linguistic and personal affinities - in the following pages, I aim to demonstrate that such a strict confessional divide did not exist; Latin notaries coexisted alongside Muslim ones, and both offered their services to a mixed clientele. Different clients sought the support of the 'udūl to guarantee the validity of their transactions in local markets and courts, and they did so irrespective of their own religion. Among the 'udūl's clients were Franks who sought locallyproduced evidence of their transactions; however such evidence only had legal value in local courts if it could be supported by those Muslims who had witnessed the transaction. Similarly, 15th-century Venetian notaries sold their services to merchants of various religious and ethnic backgrounds, particularly when recognition of their transactions was sought before Frankish associates and legal institutions. Thus, two Latins could have recourse to the 'udūl to "seal their engagements," and conversely, there are many documented instances of Muslims requesting the services of Venetian clerks for their transactions with Frankish merchants. Finally, although this was much rarer, two Muslim parties could underwrite a Latin contract before a Venetian notary. ${ }^{186}$

184 Diplomatarium veneto-levantinum sive acta et diplomata res venetas graecas atque levantis illustrantia, edited by G.M. Thomas and R. Predelli. Vol. 2, Venezia: Deputazione veneta di storia patria, 1880-1899, I 295 (art. 22), For fifteenth-century treaties signed with Barcelona, Florence and Venice, Ruiz-Orsatti, Reginaldo, "Tratado de Paz entre Alfonso V de Aragón y el sultán de Egipto, al-Malik al-Ashraf Barsbay", Al-Andalus 4 (1939), 333-389, 343, 345, 361 (art. 11, 15, 26), Wansbrough, John: "A Mamluk Commercial Treaty Concluded with the Republic of Florence, 894/1489", in: Documents from Islamic Chanceries, edited by S. M. Stern, Oxford: Bruno Cassirer 1965, 39-79, Wansbrough, John, "Venice and Florence in the Mamluk Commercial Privileges", Bulletin of the School of Oriental and African Studies 283 (1965), 483-523, 488 (art. IV), 512 (art.v), 498:35 (art. II).

185 Popper, William: Egypt and Syria under the Circassian sultans, 1382-1468 AD; systematic notes to Ibn Taghrî Birdî's chronicles of Egypt, Berkeley: University of California Press, 1955, 1957, 1963, Part I, 97-103, 107.

186 ASVe, CI, N, B. 222, Notary A. Vactaciis, f. 17r, 2 Mar. 1400: "procuratore ... pro quadam carta moresca." Sometimes deeds were drawn up to deal with third-party Muslim associates: ASVe, CI, N, B. 83II, Notary C. Del Fiore, 2 May 1461; ASVe, CI, N, B. 148, Notary P. Pellacan, 7 Oct. 1444: "una charta moresca mi rechiedete chio fazi a chonfirmatione de uno chompromesso fatto tra ser fra Antonio Mozzo e me"; ASVe, Notarile Testamenti, 
Aside from giving us insight into cross-confessional recourse to notaries, the Venetian outremer clerks can also help us understand two major areas of interaction: first, the promiscuous use of legal artifacts, and specifically Islamic records produced by the parties to support claims to Latin contracts, and second, the action of legal agents in contexts that fell outside their own legal system. References to the mixed use of documents are relatively frequent. In 1435, for example, a certain Abdrexach submitted to the Venetian notary of Alexandria an Arabic document written by a long-term Florentine resident in Egypt, Francesco Mannelli, where the latter acknowledged his debts to the former. Abdrexach had the private document notarized and later requested that the notary draft a power of attorney. With this second document, Abdrexach appointed a Genoese agent to recover his debts on his behalf back in Christian lands, with particular mention to the courts of Rhodes. ${ }^{187}$ In another similar case from 1400, a Jew from Crete gave an Islamic power of attorney to a Rhodes consul, empowering the latter to retrieve debts traceable in Latin deeds. ${ }^{188}$

Interactions across legal systems are obviously easier to trace in the protocols of the Levantine outremer notaries than in those drafted in the metropolis. It has been noted that there are no discussions in Latin jurisprudence of how to deal with proof produced in the language of infidels, or under exogenous legal systems. ${ }^{189}$ Such issues were instead dealt with in practice, and it seems that similar procedures were also implemented by Latin notaries when handling cross-confessional business deals. One example of this practical approach to cross-confessional cases can be found in that of the Genoese agent Giovanni Italiano, who found himself in Almería in 1483, in the very last years of Islamic rule. Italiano was acting on behalf of a Venetian merchant called Andrea Mocenigo, and reclaimed the debts owed to the latter by a Muslim merchant named Macomet Ubecher. Mocenigo had agreed to sell spices to Ubecher, but had for some reason preferred to stay aboard a Venetian galley and appoint Italiano as his attorney on land. For his part, the Muslim argued that the entire arrangement was not compliant with Islamic law, refused to

B. 215, Notary S. Peccator, 14 Oct. 1448; ASVe, CI, N, B. 211, Notary N. Turiano, f. 6r-v, 21 May 1455 .

187 ASVe, CI, N, B. 211, Notary N. Turiano, f.36v, and f.38 r-v, February 8, 1435. "quadam carta debiti in lingua arabicha scripta nobili et egregio viro Francisco Mannelli quondam Rinaldi [...] super quam cartam sunt anotate due subscriptionis manibus christianorum franchorum".

188 ASVe, CI, N, B. 222, Notary A. Vactaciis, f. 17r, March 2, 1400: "procuratore ... pro quadam carta moresca."

189 Airaldi, Gabriella, "Genovesi nel mondo islamico: « carta sarracenica » e « carta in arabico »", Critica Storica IX/1 (1972), 106-121. 
recognize Italiano as Mocenigo's attorney, and declined to pay. Italiano responded by demanding that Macomet Ubecher put his refusal in writing, which he accepted. A group of five Genoese merchants in Almería undersigned the Arabic document, giving testimony that Ubecher had effectively written the deed with his own hand. Four of them signed in Latin, and one in vernacular Genoese. Indeed, this exact same procedure was also followed by the Florentine Francesco Mannelli just mentioned, who had his due bill undersigned by fellow Christian witnesses.

Later that year, in December, a certain Giovanni Doria showed up at a notary's office in Genoa in the company of some Venetian representatives. Doria asked the notary to have Ubecher's Arabic document translated, and have a notarial deed based on it drawn up. The notary found himself obliged to call upon two Muslims settled in Genoa-Sadat Abeyn Aven, son of Muhammad, from Granada, and Ucoy son of Saad Ariz from Tunis-fluent in both the Spanish and Genoese vernacular languages. ${ }^{190}$ Both attested that the document was an original and, apparently, translated the record by reading it aloud. This would not suffice to the notary who called on the additional services of two Genoese merchants knowledgeable in Arabic, vernacular Genoese and Spanish. ${ }^{191}$ These Genoese, in their turn, attested to the correctness of the translation provided by the two Muslims. The document is silent as to the reasons for this complicated procedure, although in addition to validating the version provided by the Muslims, I conjecture that the two Genoese had knowledge of spoken Arabic but were unable to read it. By drawing up these testificationes, then the instrumentum registrationis et traductionis, and by incorporating them into his protocol, the notaries Testa and Foglietta were able to give public faith to an Arabic private deed.

Two observations can be made about the exceptional procedure described above. First, that an Arabic record was converted into a Latin notarial deed

190 "Fuit suprascripta scriptura traducta de lingua arabicha in linguam vulgarem ianuensem et ispanam per interpetres, videlicet Sadat Abeyn Aven quondam Macometi, mercatorem regni Granate et Ucoy filium Saad Ariz, mercatorem Tunetis, mauros existentes in presenti civitate Ianue, afirmantes eorum iuramento quod dictam scripturam in lingua arabicha scriptam fore scriptam manu propria dicti Machometi Urbeche.", ASG, Notai Antichi 1144bis, not. Pellegro Testa, n. 316.

191 "et expertos et in vulgari ydiomate et sermoni Ianuensium, vulgari Ianuensium et yspani, presentibusque in hac eadem traductione nobilibus viris Guillelmo Embrono et Gotifredo Spinula, civibus Ianue, ambobus expertis dicte lingue arabice et yspane ac lattine afirmantibus sub eorum iuramento tactis corporaliter scripturis sese intelexisse mediantibus dictis mauris legentibus dictam scripturam, ipsam traductionem fuisse vere factam.", ASG, Notai Antichi 1144bis, notary Pellegro Testa, n. 316. 
thanks to its undersigning by several Christian witnesses on the beach of Almería, and as a result was subject to a certain degree of hybridization. Secondly, the statement given by Macomet Ubecher was not even notarized by a shāhid and proper witnesses, making it all the more risky for the notary to endow it with executive legal validity (severe penalties could be imposed in case of forgery, such the notary's hand being cut off-a punishment that was equally reserved for Ottoman notaries). ${ }^{192}$ Overall, however, the view that proof established by unbelievers was accepted if fully compliant with evidentiary standards does not apply here. It is perhaps for this reason that Giovanni Doria returned several times the notary workshop, in an attempt to definitively wrap up the Almería issue. In November, he requested that two Genoese citizens certify the trustworthiness of the Almería document (referred to as "litteris mauritaneis in appapiro scriptis"). They witnessed to the fact that the Genoese signatures in the Arabic document ("sub quibusdam litteris mauritaneis") were original; these witnesses attested knowing these merchants' handwriting, since they had received letters from them in the past. As if the public faith of a single notary did not suffice, the deed was transferred to a second notary, Oberto Foglietta, with Pellegro Testa now acting as scribe and witness to the deed. In addition, the chapel of Genoa's notarial guild was chosen as the place of signature for the deed, in an attempt to lend further credibility to its registration. ${ }^{193}$

Grounded as they were in very different juridical traditions, Latin and Muslim notaries had very different approaches to the fundamental issue of evidence and proof; however, in practice they complemented each other. The validity of acts drawn up by the 'udūl was tied to the local courts, while Latin deeds had to secure rights back in Europe, where they had probative value. The two institutions together produced evidentiary artifacts to legalize private transactions, to aid arbitration panels, and to guarantee the validity of private contractual arrangements before the parties entered into a lawsuit. In court, only professional witnessing by the 'udūl was acceptable to the qadis. However, the Mamluk officers acting as judges in Siyāsa trials were an exception to this rule, in that they seem to have reached decisions not only on the basis of notarial deeds, but also correspondence, written accounts, and other kinds

\footnotetext{
192 Carosi, Carlo: "II tradimento della fides: il falso", in: Hinc publica fides. Il notaio e l'amministrazione della giustizia, edited by V. Piergiovanni, 127-151. Milan: A. Giuffrè, 20o6, 141, Fodor, P., "How to forge documents? (a Case of Corruption within the Ottoman Bureaucracy around 1590)", Acta Orientalia Academiae Scientiarum Hungaricae 483 (1995), 383-389, 385 .

193 ASG, Notai antichi, 787, Oberto Foglietta doc. 53, 25 November 1483.
} 
of written evidence produced by unbelievers. Describing Ibn Qayyim's reflections on the regime of proof, Baber Johansen aptly stresses that daily governance inevitably had to deal with an "altered normativity" (shar'mubaddal). ${ }^{194}$ Dealings with the Franks fell within this category—a point that I will develop later in this chapter-and, accordingly, during the 14th century commercial cases dealing with all kinds of foreigners, ranging from Persians to Franks, were transferred to officials who served in the capacity of judges. The Islamic notarial system, moreover, interacted with that of the Latin scribes to a greater extent than has been traditionally been held, as did notarial agents. Descriptions of the Siyāsa trials held in Damascus tell us that, on occasion, judges relied on the collaboration of Venetian notaries. The consulate clerks could be called before the Siyāsa judges, for example, to hold the scriptures upon which Frankish defendants took their oaths. Conversely, at least in Damascus, some scribes were specialized in recording the transactions contracted between Latins and Muslims, apparently on the basis of their linguistic expertise.

\subsubsection{Merchants and Notaries in the Eastern Mediterranean}

The earliest surviving collection of a substantial number of Latin deeds produced in the Levant are in the papers of the notary Giovanni Campione, who stayed in Alexandria for twenty-three months between 1361 and 1363. Of the 165 people mentioned in his notebook, only one identified himself as an Eastern Christian, and one other is labeled as a Muslim. ${ }^{195}$ As Egypt and Syria became the center of networks dealing in the spice trade, the notary's task became ever more complex. In extant fourteenth-century casebooks, notarial deeds almost exclusively concern Latins. However, in the fifteenth century, it was not only local Muslims, but characters from a variety of backgrounds that found their way into the protocols. In order to mark a clear distinction between the religious minorities under the protection of the Western powers, and those who were subjects of the local Islamic state, the Latin notaries enlarged their formulaic, largely fossilized Latin terminology. Hence, the dhimmì Jews were sometimes referred to as judeus ebraicus, as a way to distinguish them from the Jews of Venice. ${ }^{196}$ On occasion, the notaries adapted their terminology to clearly identify Muslims (for instance, as "Saracen Moors"), as opposed to the

\footnotetext{
194 Johansen, "Signs as Evidence", 182.

195 ASVe, CI, N, B. 36, Notary G. Campione, Oct. 27, 1362 : christianus a centura, Oct. 28, 1362, Oct 30, 1362: saraxino.

196 ASVe, CI, N, B. 23o, Notary N. Venier, f. 13r, 3 Apr. 1419: "cuidam Ellie, judeo ebraicho, illo tunc existenti in Damasco et ad presens habitatori dicte civitatis Nichosie."
} 
more common Arabic-speaking Christians. ${ }^{197}$ Muslims could also be identified as "foreign," like the Maghrebis, or vassals of Christian rulers such as the Iberian Muslims. Consequently, in their Latin jargon the notaries conveyed individuals' jurisdictional location as best they could, as in the complex case of Abdella, judeus ebraicus magrabi de Tunisio, habitator in Damasco. ${ }^{198}$ The major challenge, however, was labeling the different kinds of Christians. Most often, Oriental Christians were indistinctly categorized as "Christians of the Girdle"; however the notary also had to deal with members of Oriental churches living in Cyprus, or elsewhere in the former Byzantine territories, who, to avoid confusion, were labeled differently.

The complexity of the notarial taxonomies is particularly visible in deeds where Oriental Christians from Islamic lands engaged in business transactions with their coreligionists from places such as Rhodes or Cyprus. ${ }^{199}$ In such circumstances, complex juridical situations that are difficult for us to reconstruct could hide behind the vague religious and ethnic categories used by notaries. We have two examples of Latin clerks who used the word fazolati to describe the Arabic-speaking Christian minority operating mainly from Cyprus. ${ }^{200}$ Indeed, the increasing complexity of notarial terminology, which reached its peak by the fifteenth century, suggests that Venetian clerks were operating at the intersection of two spheres of jurisdiction, which transcended a simplistic model of Christian-Muslim dichotomy. The matter was of crucial importance, as the Christians and Jews of Islam were charged only half the amount of taxes as their coreligionists subject to Christian powers. This meant that both the notaries and the Mamluk secretaries were increasingly faced with the legal issue of determining whose jurisdiction these Christians and Jews fell under. While the Venetian notaries' response was to adopt an increasingly complex terminology, the chancery manual by al-Sahmmāwī suggests that discussions revolved more around identifying the different Christian sects, in order to clarify which were led by Oriental patriarchs, and therefore which individuals

\footnotetext{
197 ASVe, CI, N, B. 230, Notary N. Venier, f. 9v, 18 Oct. 1418: "aliquibus mercatoribus saracenis moris."

198 ASVe, CI, N, B. 23o, Notary N. Venier, f. 13r, 4 May 1419.

199 For references to mixed Christian networks: ASVe, CI, N, B. 222, Notary A. Vactaciis, f. 74V, Oct. 2oth, 1404, f. 183v, July 29th, 1405, ASVe, CI, N, B. 211, Notary N. Turiano, f. 59v, Oct. 4th, 1455 .

200 ASVe, CI, N, B. 222, Notary A. Vactaciis, f. 8or, 3 Dec. 1404: "Salem façolato habitatori nicosie presenti et intelligenti per Nessinum interpretem venetorum lingua Arabica"; ASVe, CI, N, B. 230, Notary N. Venier, f. 19v, 29 May 1419: "in su laqual nave I era haver de mori e fazolati."
} 
should be considered subjects of the sultan, irrespective of where their members lived. ${ }^{201}$

During the fifteenth century, Muslims and Christians who were subjects of Islamic states became frequent clients of Venetian notaries. They often gave power of attorney to Franks, for matters ranging from the capture of a slave to the recovery of debt. ${ }^{202}$ Providing services to these Mamluk subjects implied the de facto acceptance that the validity of notarial deeds was universal (ubique terrarum), at least in the territories under the theoretical jurisdiction of the Roman Empire, which included the Mediterranean Levant. ${ }^{203}$ Together with the very idea of public faith, this second legal fiction permitted notaries to present themselves as a universal institution to which any merchant could appeal. Moreover, by extending their services to individuals under Islamic jurisdiction, notaries were implicitly granting public faith to their legal documents. The notary often quoted documents in Arabic, generally referred to as Moorish letters, but also in Hebrew, presented by clients as evidence of previous business relations. The Venetian clerks had account books and customs records translated, and, on occasion, they made references to private Arabic acts and contracts. ${ }^{204}$ Among these documents, we can find Islamic notarial deeds drawn up by the 'udūl and validated by witnesses. In a much-disputed case, two Muslims were called to witness an agreement between a Florentine consul and a Venetian jeweler in Alexandria ("ad conficiendum saltem pro duos testes mauros unam cartam morescam"). These Moorish letters were later used to resolve disputes before Christian courts in Alexandria and Rhodes. ${ }^{205}$ Similarly,

201 al-Saḥmāwī, al-Thaghr al-bāsim, 424-8. As for the classic system of taxation ('ushr) applied to dhimmīs and harbīs, see Ibn Taymīyah, Aḥmad Ibn 'Abd al-Ḥalīm (12631328): al-Siyāsah al-shar'ìyah fì ișlăḥ al-rāì wa-al-ra'ìyah, edited by 'Alī Ibn Muhammad 'Umrān, Mecca: Dār 'Ālam al-Fawāìd, 1429 H, 55-6.

202 ASVe, CI, N, B. 222, Notary A. Vactaciis, f. 41r, 25 Feb. 1401; f. 119v, 16 Aug. 1406; ASVe, CI, N, B. 22, Notary V. Bonfantin, 28 June 1419; ASVe, CI, N, B. 23o, Notary N. Venier, f. 5v-6r,18 May 1418; f. 6r-v, 16 May 1418; ASVe, CI, N, B. 148, Notary P. Pellacan, 9 Nov. 1444; ASVe, Notarile Testamenti, B. 215, Notary S. Peccator, 10 Oct. 1448; ASVe, CI, N, B. 83II, Notary C. Del Fiore, f. 15V, 14 June 1426; f. 24r, 30 May 1426; ASVe, CI, N, B. 211, Notary N. Turiano, f. 38,8 Feb. 1435 .

203 Airaldi, Studi e documenti su Genova e l'oltremare, 209, Murray, Notarial instruments in Flanders between 1280 and 1452, 11.

204 ASVe, CI, N, B. 222, Notary A. Vactaciis, f. 17r, 2 Mar. 1400, mentions an Arabic contract drawn up in Cyprus; ASVe, CI, N, B. 83II, Notary C. Del Fiore, 2 May 1461: vigore certe carte arabice, se constituerit plezium. As for contracts in Hebrew: vigore unius scripti anotati in ydiomate ebreo, ASVe, CI, N, B. 211, Notary N. Turiano, f. 66r, 26 July 1428.

205 ASVe, CI, N, B. 148, Notary P. Pellacan, 7 Oct. 1444; ASVe, CI, N, B. 211, Notary N. Turiano, f. 38,8 Feb. 1435, an Arabic contract is produced as evidence to be used before Rhodian courts. 
Franks who went into partnerships with Muslims often made use of Arabic contracts ("cartas, instrumenta et scripturas lingua Arabica scriptas"). ${ }^{206}$ It has been argued that legal relations between Franks and Muslims were limited to the occasional validation of either party's probative artifacts; ${ }^{207}$ according to this vision, evidence produced under the Islamic system was accepted by Franks only if compliant with Islamic rules of proof, and vice versa. However, the combined, mutually enforced use of legal instruments that we have seen here suggests that legal relations went beyond a simple Islamic/Frankish polarity, and in reality had a truly multi-faceted configuration. As Kate Fleet has suggested for judicial cooperation in pre-Ottoman Turkey, notarial culture contributed to the full and mutual integration of Frankish and Mamluk legal devices. ${ }^{208}$

Depositions and sworn testimonies by Muslims are a recurring feature in the ledgers of Latin notaries. They accepted statements in Arabic and in Turkish, whose contents could be asserted either by official dragomans (interpreters) or by simple merchants. Hence, someone might speak "in a translated voice" (dixit et testificatum fuit suo sacramento iurando per vocem turcimatam) or be "understood" (intelligenti pro interprete lingua Arabica) through the intermediary of a third party. ${ }^{209}$ One such example is the a disagreement that arose in 1404 over a shipping contract signed between two Cypriots. The contract had been drawn up in Arabic by one of the merchants, Salem, who spoke Arabic and who subsequently sought the mediation of a Venetian dragoman. The arbitration, accordingly, was notarized on the basis of the linguistic mediation and the validity of the Arabic document. Beyond this cultural sophistication delivered by notarization, mutual recognition required a certain legal accommodation, particularly with witnesses. The notary was compelled to accept oaths and testimonies from Muslim courtiers and dragomans even when, embarrassingly, they were Christian renegades. Their condition as apostates is generally made explicit (olim christianus fidelis ad presens saracenus), and indeed, although the Venetian authorities recommended that oaths by nonChristians be sworn on "their old texts", when renegades were called to swear

\footnotetext{
206 ASVe, CI, N, B. 211, Notary N. Turiano, f. 46v, 11 Sept. 1455.

207 Valérian: "Le recours à l'écrit", 68.

208 Fleet, Kate, "Turkish-Latin Diplomatic Relations in the Fourteenth Century: The Case of the Consul", Oriente Moderno 22 (83) 3 (2003), 6o5-611.

209 Examples are two sworn testimonies by Muslims: ASVe, CI, N, B. 211, Notary N. Turiano, f. 3ov, 4 Mar. 1435; and again f. 48r, 27 Apr. 1435: per vocem turcimatam cuidam vocati Acmar saraceni.
} 
on "the scriptures," we are not informed which scriptures these might have been. ${ }^{210}$

Although there was widespread recourse to Venetian notaries by the fifteenth century, could everyone be a witness? Siyāsa thinkers such as Ibn Qayy$\mathrm{im}$, and the Venetian colonial authorities were equally concerned by this issue. Gathering testimony from unbelievers represented a challenge to the accepted norms in Islamic jurisprudence because, either in court or before the notary, witnessing implied becoming an actor in the legal system, not simply a passive subject. Again, a comparative description of how norms were put into practice suggests that common attitudes were adopted in spite of doctrinal differences. Apart from the hanafis, who expressed reserves for intra-communal cases, Islamic jurists denied the right of non-Muslims to guarantee the intentions or claims of others as witnesses. As a result, the rare extant Islamic notarial acts where non-Muslim witnesses are involved always regard other non-Muslims. ${ }^{211}$ In contrast with sharīa, nothing in Venetian law prevented non-Christians from acting as witnesses to deeds, though in practice this was only the case for contracts where their coreligionists were involved. In Alexandria and Damascus, notaries stuck uniformly to this practice. ${ }^{212}$ Similarly, specialists of Genoese history underline that, even in the absence of an explicit prohibition, in practice the Jews of Genoa only acted as witnesses for deeds underwritten by other Jews. ${ }^{213}$

By shifting the focus from theoretical differences to actual practice, my intention is not to pass over the real differences between sharía and Western law. I aim rather to stress that, even in matters where Latins and Muslims relied on different legal doctrines, striking coincidences emerge in the practical ways in

210 ASVe, CI, N, B. 222, Notary A. Vactaciis, f. 8or, 3 Dec. 1404; ASVe, CI, N, B. 211, Notary N. Turiano, f. 58v-59r, 9 Aug. 1435; f. 61r, 19 Aug. 1435; f. 3or, 8 Dec. 1434; ASVe, Notai di Venezia, 14832, Notary I. Dalla Torre, f. 2 (n. 2), mentions a Genoese dragoman, "olim cristiano," 31 May 1412.

211 Ragib, Yusuf: Actes de vente d'esclaves et d'animaux d'Egypte médiévale. Vol. 2, Le Caire: Institut Français d'Archéologie Orientale, 2006, 107.

212 Non-Christian witnesses invariably appear in deeds related to other Non-Christians: ASVe, CI, N, B. 22, Notary V. Bonfantin, 17 Jan. 1393; 28 June 1419; ASVe, Notarile Testamenti, B.215, Notary S. Peccator, 2 May 1448; 5 Oct. 1448; 14 Oct. 1448; ASVe, CI, N, B. 211, Notary N. Turiano, f. 6v, 21 May 1455 .

213 On the Islamic biases against non-Muslim witnesses, Fattal, Le statut légal, 361-4. Emon, Anver M.: Religious Pluralism and Islamic Law: "Dhimmis" and Others in the Empire of Law, Oxford: Oxford University Press, 2012, 136-141, Ragib, Actes de vente d'esclaves et d'animaux d'Egypte médiévale, 105-15. For minority witnessing in the Genoese colonies, Argenti, Philip P.: The religious minorities of Chios: Jews and Roman Catholics, Cambridge Eng.: Cambridge University Press, 1970, 100-146. 
which norms were implemented. By the same token, both legal systems dealt with the judicial oath of minorities in a very similar way. In Venetian legal practice, the taking of judicial oaths by non-Christians was a familiar procedure. In Venetian Crete, a special procedure was established in 1340 to validate pledges pronounced by Jews. As infideles, they could not swear by the cross, so members of the Jewish community were subjected to a special oath-taking procedure that required their presence at the synagogue. In the same fashion, when the Inquisition started to gather depositions from Venetian Jews, they were allowed to swear to the truth of their testimony with a Jewish formula, a solution that coincides with that resorted to in sharía. ${ }^{214}$ What these apparently surprising coincidences reveal is that Islamic concepts of difference had actually been incorporated into legal practice by the Christian powers; it was the doctrine of the mālikīs, shāfi'is and some hanbalīs that recommended that Jews and Christians take their oaths in their respective houses of prayer. ${ }^{215}$ This late medieval transfer was not specific to Venice, but found its way into the legal codes of other expanding Christian powers, such as Castile, and it is a subject that I will look into in more detail in Chapter Three. ${ }^{216}$ Similarly, the biases against minority witnessing were not specifically Islamic, but had precedent in Byzantine legal concepts. The Justinian Code I.V.25 issued in September 531 set the standard for later bans on cross-confessional witnessing. It not only limited the ability for heretics to give testimony in cases concerning Christians, but also anticipated exceptions allowing them to testify for or against each other in inter-communal disputes - the Byzantine equivalent of the so-called 'hanafĩ exception' which, as we shall see, would become a mainstay of Ottoman governance. ${ }^{217}$ The

214 Santschi, Elisabeth, "Contribution à l'étude de la communauté juive en Crète vénitienne au XIVe siècle, d' après des sources administratives et juridiques", Studi Veneziani XV (1973), 177-211, 207-8, Head, R. C., "Religious Boundaries and the Inquisition in Venice: Trials of Jews and Judaizers, 1548-1580", The Journal of medieval and Renaissance Studies, 202 (1990), 175-204.

215 Bechor, Guy: God in the Courtroom: The Transformation of Courtroom Oath and Perjury Between Islamic and Franco-Egyptian Law, Leiden; Boston: Brill, 2011, 122-127.

216 Jecker, Mélanie: "Jurer selon sa religion. La figure de l'autre dans le droit médiéval castillan", in: La culture judiciaire: Discours, représentations et usages de la justice du Moyen Age à nos jours, edited by Lucien Faggion, Christophe Regina, et al., Dijon, Glick, 2014, 241269, Thomas F.: Islamic and Christian Spain in the Early Middle Ages, Leiden Netherlands; Boston: Brill, 2005 reprint, 190.

217 "We ordain that no heretic and those who cherish the Jewish superstition shall give testimony against orthodox (Christians) whether one of them is orthodox or the other. 1. But if heretics or Jews want to litigate among themselves, we permit promiscuous agreement and witnesses worthy of them to be introduced." The Codex of Justinian: a new annotated translation, with parallel Latin and Greek text based on a translation by Justice 
prejudices against female witnesses are perhaps the best illustration of this continuous borrowing of solutions for fundamental legal questions. Qurān 2:282 prescribes the need for two female witnesses to replace one man, which is often counted among one of the major legal biases of sharīa, and was generally upheld in legal practice. When the Great Council of Venice reinforced the role of witnesses for final wills and testaments in 1475 , two women were required to take the place of one man. ${ }^{218}$

It is generally agreed that fifteenth-century Mamluk governance witnessed the blossoming of merchant nations involved in the spice trade, along with their consular institutions. The interaction of scribal institutions, among a number of other factors, played a significant role in consolidating these crossconfessional dealings, and in the prevention and resolution of conflicts. Significantly enough, in the context of the general reorganization of trade routes in the early Ottoman era, this Mediterranean configuration of notarial activity ceased to exist in both Syria and Egypt. The only similar instance of an active, unbiased notarial workshop existed under the aegis of the Venetian Bailo of Constantinople, to whom a notarial clerk was attached. The Bailo's archives, which have recently been opened for consultation, suggest that similar practices were continued in early modern times, but in the far more restricted context of the Imperial capital. ${ }^{219}$ As will become clear in the following chapters, the Ottomans empowered local qadis to act as notaries and to hear mixed cases. Together with Venetian notaries, other legal actors such as the Siyāsa judges ceased to exist in the early modern era, after the advent of Ottoman rule in Syria and Egypt in 1516-7. The ways in which proof was produced in cross-confessional settings saw a subsequent, very significant turn, and in consequence the trove of solutions allowing actors to overcome the biases had to be refashioned.

\subsection{New Attitudes towards the Written}

The changes brought about by the Ottomans in the field of commercial litigation neither altered the probative status of written documents, nor that of oral witnessing. As regards procedure, descriptions of court hearings suggest that

Fred H. Blume, Cambridge: Cambridge University Press, 2016, See also Fattal, Le statut légal, 361-4.

218 Bigaglia, Capitulare, 28-9.

219 ASVe, Bailo a Costantinopoli, see the recent Ordinamento ed inventario, Bailo a Costantinopoli, a cura di Giustiniana Migliardi O'Riordan. 
cases continued to be heard in the same way as they had been in previous periods, and that proof continued to be produced by litigants according to precedent. ${ }^{220}$ Yet, in spite of normative continuity or, at best, in the context of slow legal change, early modern times witnessed the emergence of new attitudes towards the written. These attitudes were the result of technical adjustments and changes in the organization of justice, rather than due to a general shift in jurisprudence. Although the notarized deed, the hujja, retained its traditional legal recognition in sharīa, and oral witnessing continued to constitute the proof par excellence, these technical changes brought about the progressive demise of the medieval 'udūl, more extensive recourse to the qadi's court and its capacity to certify and archive documents, and, lastly, a reorganization of the 'witness system.' These changes had an enormous impact on the field of commercial litigation; the Ottoman 'invention' of the courthouse affected the practical way in which foreigners established contracts and records were certified, bringing about the disappearance of the notarial pluralism that had been built up previously under the Mamluks. Ultimately, these new attitudes towards writing and documentation culminated, to cite one major change, in a prescription against using Muslim witnesses against Franks, who could not be convicted in the absence of notarized contracts. Jurists did not necessarily agree with the validity of such measures, which were at odds with sharīa, and the jurisprudence contained in collections of fatwās continued to adhere to traditional approaches to proof and procedure. The following section is an attempt to identify the piecemeal modification of some aspects of the law in the Ottoman era, and in particular the regime of proof that meant that cross-confessional relations looked very different in comparison with medieval times.

\subsubsection{New Attitudes and Archives}

Probably due to researchers' reluctance to admit to the absence of medieval archives, specialists of Ottoman legal practice have often assumed that some kind of archive should have existed for medieval judges, and have refrained from claiming that the Ottomans invented the judicial archive. ${ }^{221}$ However, as Reem Meshal, among other authors, has acknowledged, the mahkama brought about crucial changes in the consumption and preservation of records. For instance, it is generally admitted that it was the Ottomans who first provided a stable storage facility for records-i.e., an archive-particularly in large

220 Canbakal, Society and politics in an Ottoman town: 'Ayntab in the 17th century, 149.

221 Peirce, Morality tales: law and gender in the Ottoman court of Aintab, 98-102. 
administrative centers. ${ }^{222}$ Notarial personnel were also appointed to register cases at courts in Damascus. ${ }^{223}$

To account for this transformation, Halil Inalcık has highlighted the specific needs of Ottoman judges, derived from the application of administrative, customary law in the Ottoman provinces. The increasing production of state or public law, the kanun, played an important role in the development of archives. İnalcık has pointed out that the need to refer to precedent to inform new cases encouraged Ottoman qadis to archive their decisions, together with copies of the customary law codes - the kanunnames - and related decrees, or kanun hukms. ${ }^{224}$ The kanun encoded the legacy of legal practice, complementing the provisions of the jurists, issued and sponsored by the dynasty, and it was often referred to as 'customary' (Tr. örfi) law. The written nature of kanun is all the more important in that it stood in marked contrast with medieval practice. Early Ottoman governance crystalized around this specific feature, the promulgation of the kanunnames, while, it is generally agreed that such a corpus of public law never existed for the medieval sultanates. ${ }^{225}$

To cite Nicolas Michel's blunt evaluation, "the Mamluks did not have written laws." This rather bold statement stresses that in medieval times there was a tendency to consider legal acts as being bound solely to the sultan that had issued them, and only during his lifetime. Indeed, this notion appears to have impregnated Mamluk governance, and doubtless hampered the development of archives. In recent years, however, an interesting debate has revolved around the Mamluk precedents of kanun. Ottoman rulers alluded in legal texts to the "Kanun of Qāytbāy" (ruled 1468-1496), assuming that citing similar legislation issued by previous respected sultans would endow Ottoman regulations with additional legitimacy. Evidence of these legal texts has not been found, although the Franks also referred to the "old laws of Qaytbay" being enforced as late as $1560 .{ }^{226}$ Of course, the Cairo chancery emitted decrees (marāsìm)

222 Faroqhi: "Sidjill", Encyclopaedia of Islam, Second Edition, IX:538b.

223 Bakhit, Muhammad A. S., "The Ottoman Province of Damascus in the sixteenth century", Ph.D. Thesis, University of London, School of Oriental and African Studies, 1972, 138.

224 İnalcık, Suleiman the Lawgiver and Ottoman law, Aykan, Rendre la justice à Amid: procedures, acteurs et doctrines dans le contexte ottoman du XVIIIème siècle, 145, Fitzgerald, Ottoman methods of conquest, 222.

225 Burak, Guy, "Between the Kānūn of Qāytbāy and Ottoman Yasaq: A Note on the Ottomans' Dynastic Law", Journal of Islamic Studies 261 (2015), 1-23.

226 ASVe, Senato, Dispacci Consoli, Egitto B1, 23, Mar. 8, 1559, Consul Giambattista Querini complains about an alleged decree by Qaytbāy granting universal protection granted to Frankish traders arriving in Alexandria and upheld until his own time, abused by corsairs, "Che io potro non dando un quatrino al moro del navilio, son per ridurmi in Allexandria dove saro libero di questi periculi come sono li sudiiti del re di Spagna per fino ancho 
to implement Mamluk governance, which covered a diverse array of themes; however, they were executed by ad hoc deputies, called khașșakīs, through military officials and civil secretaries, and such decrees largely remained outside of the remit of the judicial sphere. All this conspired to hinder the development of a Mamluk qadi archive, while in contrast Suleiman's kanunname exhorted judges to archive and transmit the sijill containing, among others, their decisions in 'örfi cases.' "Thus," İnalcık concludes, "for the history of Ottoman law, every copy, especially the annotated ones at the courts, had the merit of an original." ${ }^{27}$ Similarly, another process fundamental to archive-making was the tendency to centralize the attribution of timar revenues; designating timar-holders in Istanbul and not in the provinces meant that a central register developed, with a growing staff of clerks to manage it. ${ }^{228}$

There existed an Ottoman chancery archive, since the Imperial Dìvān has left traces of its activities in two series preserved at the Başbakanlık Osmanlı Arşivi. I believe that this groundbreaking development owed as much to the role of the Imperial Divañn as a court of justice, as to its activities as a diplomatic forum, a point that I will elaborate below. ${ }^{229}$ Descriptions of the role of the Nişancl - the head scribe of the Ottoman court—and, later, that of the Re'iss ül-Küttāb, however, suggest that these officials were more responsible for transmitting drafts to the sultan for approval, than they were for keeping diplomatic decisions and records. ${ }^{230}$ Emphasis was laid, not on preserving diplomatic records in a central archive, but on the signing of documents with the tughra, the sultan's monogram, without which they lacked any legal value. On their side, Venetian envoys insisted on the importance not of drafting the final, physical document, but on its authentication by Muslim witnesses. ${ }^{231}$ It is in this sense revealing that early in the 16th century a whole industry for the forgery of fake decrees grew up, involving scribal staff, mainly through the reuse of old decrees signed with the official tughra, a technique similar to the recycling

Maltesi et li ladri medesimi che vano in corso sotto habito de mercanti per privilegio di una antigua leze del condam Cait Bej fu soltan del cairo che sicura hogni nacione che vien per mercanzia in Allexandria."

227 İnalclk, Suleiman the Lawgiver and Ottoman law, 117.

228 Howard, D., "The Historical Development of the Ottoman Imperial Registry "(Defter-i Hakanî)": Mid-Fifteenth to Mid-Seventeenth Centuries", Archivum Ottomanicum 11 (1986), 213 .

229 Faroqhi, Suraiya, "The Venetian presence in the Ottoman Empire (160o—163o)", The journal of European economic history 152 (1986), 345-384, 353.

230 Deny, J:: "Re’̄is ül-Küttāb", in: Encyclopaedia of Islam, Second Edition, viıI: 481b: Brill.

231 Işiksel, Güneş: "Hierarchy and Friendship: Ottoman Practices of Diplomatic Culture and Communication (129os-16oo)", The Medieval History Journal, 2019: 1-20, 5. 
of 'black market' clay seals mentioned by Ibn Iyās (cf. 2.2.3) or to the rewriting of discarded deeds described by al-Jawbarī. ${ }^{232}$ Again, assuming that the preservation of all official records was a necessity for all literate societies may be misleading inasmuch as, for early modern Muslims, preserving documents ran the risk of their being used out of their original context.

It would be inaccurate to assume, however, that new attitudes towards writing and documentation were solely limited to or defined by the practice of registering deeds, and even less an alleged 'triumph of the written' in sharīa courts. Researchers have revealed many elements of continuity with the medieval past in terms of judicial practice. According to 16th-century hanafis such as Ibn Nujaym (1520-67), judges were expected to grant all subjects access to their sijills and to deliver copies to the right holders. ${ }^{233}$ If, out of court, this meant that actual rights were now recognized for many subjects of the legal system, this was not in antagonism with the traditional ceremony of justice. The weight of oral and written proof in legal procedure has been thoroughly studied by Boğaç Ergene, who, by examining the qadi courts of small communities, has concluded that Ottoman litigants and judges tended to respect the preeminence of oral witnessing. ${ }^{234}$ Written documents were advanced as proof, but litigants had almost no chance of success if these contracts could not be backed by oral witnessing. Although depositions by witnesses were now included in the sicil—therefore giving historians access to these voices-we should keep in mind that these depositions and the witnessing that accompanied it were transcribed very summarily in court proceedings. Even when transcripts were established, they continued in practice to serve simply as aide memoires for actual witnessing. ${ }^{235}$

\subsubsection{Legal Reform and the Written}

Alongside the continuity of judicial practice between the Mamluk and Ottoman eras, current research has also identified elements of change: although in principle the oral nature of proof was not fundamentally compromised, the

232 Fodor, "How to forge documents? (A Case of Corruption within the Ottoman Bureaucracy around 1590)".

233 Ibn Nujaym, al-Ashbāh wa-al-nazāàir 'alá madhhab Abī Hanīfah al-Nu'mān, 293.

234 Ergene, "Evidence in Ottoman Courts: Oral and Written Documentation in Early-Modern Courts of Islamic Law", Wilkins: "Witnesses and Testimony in the Courts of SeventeenthCentury Ottoman Aleppo", Cohen, Amnon: Jewish life under Islam: Jerusalem in the sixteenth century, Cambridge, Mass.: Harvard University Press, 1984, 110-140.

235 Masters, Bruce Alan: Christians and Jews in the Ottoman Arab world: the roots of sectarianism, New York: Cambridge University Press, 2001, 31-33, Imber, Ebu's-su'ud: the Islamic legal tradition, 53 . 
Ottomans' changing attitude towards proof was not without consequences. From the beginning, Ottoman reform concentrated the power to notarize and register most contracts in the hands of Ottoman, hanafi judges, to the discontent of the local judiciary. From Syria to Mecca, in the former Mamluk territories this usually meant a foreign, Turkish magistrate, at best associated with the Ottoman regime and legal traditions (referred to as yasaq) and in any case belonging to a madhhab different from the shāfīi , this latter having traditionally been dominant under the Mamluks. Ibn Fahd describes the fraught case of a pious foundation endowed by a merchant named Khawājā al-Ḥamawī in 1519 . The institution of a waqf usually meant that the heirs of a founder had to kiss goodbye to a juicy estate, and consequently attempts at fraud by the latter were a temptation. ${ }^{236}$ The merchant's daughter tried to circumvent the testament with the assistance of a corrupt Māliki judge, who pressured a local notary to steal the receipt (mustanad) associated with it. Both parties tried to build their case on the basis of notarized testimonies, however because depositions had to be registered (tasjil) by the hanafí judge and included in his sijill, he had the final word in most quarrels. The notary was investigated and questioned, and finally admitted to his role in the disappearance of the receipt. A dispute eventually arose between judges and witnesses from different madhhabs, and during discussions an Ottoman official, the shāhbandar of Jedda, stated that the truth was that the notary had lied and had to be dismissed, and that "this was the law in his own time, and so it should be under the Ottoman yasaq" (alyasaq al-uthmānī). 237

As portrayed by Ibn Fahd, early Ottoman notaries often appear involved in similar quarrels revolving around the estates of the deceased. Rather than notarizing private contracts in their stalls, they are mentioned as legalizing through their testimonies the legal acts associated to inheritances. In a much embroiled case, two factions in the judiciary litigated over the estate of a deceased qadi named Jamāl al-Dīn al-Murshidī. Notaries suffered pressures from both parties in order to modify their statements. They were instrumental in having al-Murshidì's initial will legally disqualified, for which the other spent

236 Gökbilgin, Tayyib: "La preuve et le témoignage dans la jurisprudence des Fetva d'Ebussud et quelques exemples d'application aux tribunaux ottomans du XVI siècle", in: Recueils de la Société Jean Bodin, La Preuve, 3, Civilisations archä̈ques, asiatiques et islamiques, Bruxelles, Editions de la Librairie encyclopédique, 1964, 205-9, Gökbilgin mentions a fatwā related to the endowment of a house as waqf that the heirs, presumably, managed to frustrate by hampering its notarial registration.

237 Ibn Fahd, Nayl al-Muná bi-Dhayl Bulügh al-Qurá, 184-5. For the Yasaq; Bakhit, "The Ottoman Province of Damascus in the sixteenth century" 139. 
money "on the witnesses and the judge". On one occasion, one of the notaries was framed when asked details about the time when he supposedly gave testimony; in another the customers denied having ever met the notary. The episode ended up with the clerk punished in front of the qadi's house, paraded through the sūqs with the head uncovered, while criers announced "this is a crooked notary who had brought discord among the judges".238

It has been noted that under the Ottomans, notary-witnesses were integrated into the mahkama, and their status reduced to that of clerks and scribes, serving as instrumental witnesses and tasked with the collection of fees. Judges charged a fee for drawing up hujjas, but also for registering them in the sicils, as well as for delivering copies. The collection of fees on marriage contracts, for example, has been identified as one of the breaches with Egyptian judiciary and, more broadly, with the local population. Muhammad Bakhit remarks that, if under the Mamluks the 'udūl made a living out of the notarization of private transactions, and judges received a state salary, the Ottoman qadis' income was dependent upon judicial fees. ${ }^{239}$ Ottoman qadis limited other scribes' access to the notarial offices as a means to secure the collection of levies, often referred to as yasaq — a derogatory term that loosely meant, in a post-conquest context, 'Ottoman custom.' And similarly, in Syria too the Ottomans adopted a policy of limiting the number of active notaries and controlling their activities. Thus in January 1517, in the aftermath of the Ottoman conquest, a 'Rūmī' judge, Zayn al-'Ābidīn Ibn al-Fanarī, decreed that each chief qadi should be limited to two notary-witnesses, and forbade the remaining freelance notaries from drawing up deeds-hence, according to Ibn Țūlūn, "severely harming the shuhūd of the country." This decision meant that all notarial activities became concentrated in the Jawziyya Madrasa, now known as the 'Hall of Law,' and that fees had to be collected for each receipt (mustanad). In particular, al-Fanarī targeted the 'udūl practice of drafting marriage contracts, now subject to judicial permission upon the collection of a Ottoman, "yasaq" tax. ${ }^{240}$

The way in which "Selim removed the notaries from their stalls" and subsequently replaced them with contending powers in their own workshops

238 Ibn Fahd, Nayl al-Muná bi-Dhayl Bulūgh al-Qurá, 308-10.

239 Bakhit, "The Ottoman Province of Damascus in the sixteenth century", 137-8.

240 Ibn Ṭūlūn, Shams al-Dīn Muḥammad Ibn 'Alī (1485?-1546): I'lām al-Wará bi-Man Wulliya Näiban min al-Atrāk bi-Dimashq al-Shām al-Kubrá, edited by Muḥammad Aḥmad Dahmān, Damascus: Wizārat al-Thaqāfah wa-al-Irshād al-Qawmī, 1964, 316-17, The same episode is addressed in his chronicle Mufäkahat al-Khillān, Ibn Țūlūn, Mufäkahat alKhillān, 338, 346-7. 
is in itself significant; it is symbolic of a very real struggle over writing and notarization, and the different meanings attached to them by Islamic governance. In February 1518, Governor Jānbirdī al-Ghazālī, at odds with the aggressive centralist policies seeking to curb the local judiciary, reinstated the system "as it was under the Circassian Mamluks," granting the 'udūl liberty to draw up deeds wherever they chose, and setting exemptions from notarization for certain types of legal acts. ${ }^{241}$ The intrigues of the judiciary fascinated the Syrian chroniclers of the day; although their interpretations of these facts differ slightly, according to al-Ghazzì, Governor Jānbirdī clashed with the local hanafĩ qadi Walī al-Dīn al-Farfūr. The leading clan of the Mamluk judiciary under the reigns of Qāytbāy (1468-1496) and Qānșūh al-Ghawrī (1501-1516), The Farfür family had long taken advantage of their responsibility to handle nominations to judicial charges, largely to their own benefit. As the overlord of the Syrian administration of justice, Walī al-Dīn al-Farfür had succeed in becoming integrated into the Ottoman system as chief qadi, and by converting to the now-dominant hanafì rite. Ottoman reforms "pointed towards the adoption of yasaq," and al-Farfür himself "persisted in the kanun of the Turks." Governor Jānbirdī al-Ghazālī, who sought to present himself as defender of the traditional order, forced al-Farfür into exile. Between September 1520 and February 1521, the province of Damascus witnessed Jānbirdī's short-lived revolt against his Ottoman overlords, a major episode in the history of the Ottoman conquest, and in which the new attitudes towards writing and documentation had their part to play. ${ }^{242}$

Ottoman reforms aimed to keep three vital functions in the hands of the hanafï, Ottoman judges. In newly-conquered Egypt, judicial policies targeted the local, non-hanafí judges' right to pass verdict on important matters, their

241 Ibn Țūūn, Mufākahat al-Khillān, 348, 386-7.

242 al-Ghazzī, Najm al-Dīn Muḥammad Ibn Muḥammad (1570-1651): al-Kawākib alsā̉irah bi-a'yān al-miah al-āshirah, 3 vol, Beirut: Dār al-Kutub al-'Ilmīyah, 1997, I, 1701. Ayalon, David, "The End of the Mamluk Sultanate (Why did the Ottomans spare the Mamluks of Egypt and wipe out the mamluks of Syria?)", Studia Islamica 65 (1987), 125148, 136. Alsabagh, "Before Banks: Credit, Society, and Law in Sixteenth-Century Palestine and Syria", 55-63, Meshal, Sharia and the Making of the Modern Egyptian, 87-9. Alsabagh's reading of Ibn Țūlūn stresses a continuity with the previous regime in al-Farfür's behavior, while Meshal presents him as a victim of Ottoman changes in the judiciary. In general, on Ibn Farfür and the Syrian judiciary, see Mandaville, The Muslim Judiciary Of Damascus In The Late Mamluk Period, Princeton University, Ph.D., 12-66, Martel-Thoumian, Les civils et l'administration dans l'État militaire mamluk (IXe/XVe siècle), Martel-Thoumian, Bernadette: "Al-Diyā̄ al-Mawfūr fi A'yān Banī Farfūr: un exemple de littérature prosopographique", in: Actas XVI Congreso UEAI, Edited by C. Vázquez and Miguel Ángel Rodríguez, 323-335, Salamanca: Agencia Espanola de Cooperación Internacional, 1995. 
right to engage in independent legal reasoning, and their grasp of witnessing and notarizing. Although the judges in Arab provinces were less affected, these reforms were bad news for the medieval 'udūl, whose weight in courts and administrative offices was curtailed by the Ottoman reorganization. Part of the struggle for the judiciary was played out in the field of the production of proof, and particularly, written proof, at a time when a general increase in the use of writing and documentation has been noted. Insofar as concerns qadi local courts, Yavuz Aykan has argued that the recourse to written documents cannot be reduced to the issue of validity in court, since the qadi provided notarial services for a wider range of social relations and transactions. The research of Leslie Peirce, Gilles Veinstein or Nicolas Michel, as well as that of Reem Meshal for Egypt, or Rosistza Gradeva for the Balkans, all concur that the recourse to notarization, now provided by the judge, became generalized in early modern Middle Eastern communities, and people began making unprecedented use of documents, although not necessarily as evidence to be used in a trial. There is therefore no contradiction between the Ottomans' attempt to undercut the influence of the notary-witness, and the parallel tendency towards writing and documentation becoming a more present feature in society. Ottoman policies sponsoring notarization extended to foreigners and minorities, since they could not testify against Muslims in court and would have benefited from a greater reliance on notarized deeds compliant with sharīa. ${ }^{243}$

In some respects, Muslim women experienced similar limitations to minorities; they are frequently mentioned as benefiting from the new role of documents in society, together with other disadvantaged groups, such as former slaves. ${ }^{244}$ This situation was in stark contrast with women's access to the notarial services under the Mamluks; indeed according to Arab chroniclers, trustworthy notaries took great care to avoid contact with female and, sometimes, minority clients. A witness to the Mamluk-Ottoman transition, Ibn Tūlūn was much preoccupied with the notaries' misbehavior, and addressed repeated accusations against some notarial workshops, such as those in the Bāb al-Ṣaghīr district in Damascus. As a result, some of the notaries of this district ended up in prison, and the markaz was involved in the embezzlement of estates

243 Faroqhi, "Before 16oo: Ottoman attitudes towards merchants from Latin Christendom", 77, Faroqhi: Sidjill, Encyclopaedia of Islam, Second Edition, IX:538b.

244 Meshal, Sharia and the Making of the Modern Egyptian, 134-9, Peirce, Morality tales: law and gender in the Ottoman court of Aintab, 371-4, 388-9, Aykan, Rendre la justice à Amid: procedures, acteurs et doctrines dans le contexte ottoman du XVIIIème siècle, 130-5, Alsabagh, "Before Banks: Credit, Society, and Law in Sixteenth-Century Palestine and Syria", 318. 
endowed as waqf. The setting of most marākiz near Damascus' city gates, close to the suburbs where uprooted immigrants from the countryside settled, did not certainly get the notary's stall much respectability. Other workshops were located in the financial districts, where foreigners resided, such as one in the Khān al-Sulțān, an inn hosting Frankish merchants and other travellers. ${ }^{245}$ Ibn Tuulūn recounts that in 1491 the governor of Damascus had the notaries removed from the Omayyad Mosque and transferred to one of the city gates due to their poor reputation. As proof of this he claims that the "udūl "were said" to have had relations with dhimmīs and women. Denoting a similar attitude, a notary of Aleppo conspicuously refused to notarize deeds for female clients, which Ibn al-Hanbali (1502-1563) judged to be an "excess of piety" 246 We might conjecture then that female or minority clients, considered to be socially weak, were more likely to be exposed to potential abuse by corrupt 'udūl, and that consequently their presence at the notaries' stall could be regarded as suspicious, or at best undesirable, and in any case unsuitable for the Omayyad Mosque.

New attitudes towards writing and notarization encompassed the disciplining of the notarial practice, and its confinement to the physical space of the courthouse, hence making it more available to all subjects of the legal system. These individuals now came to the court to register, in the form of hujjas, their family and marital status, or to attest to their being freed from slavery. The criticisms to medieval notaries by Arab authors suggest that right holders needed to keep alive their claims, in the same manner documents were kept valid through tasjil procedure. For the Ottoman period, Reem Meshal has found evidence of the recipients' capacity to request copies of hujjas confirming their rights, whose originals were kept in official archives, and these documents could be exhibited in other places in the Empire without recourse to oral validation by witnesses. Irrespective of the actual scale of this phenomenon, it suggests a major break with medieval attitudes towards the production and archiving of proof.

\subsubsection{Judicializing the Written, Writing Judicially, and Handling Orality}

New approaches to the legal validity of the written were not only limited to administrative practice, but also extended to the field of jurisprudence. In his

245 Mandaville, The Muslim Judiciary Of Damascus In The Late Mamluk Period, 121-2, Apellániz, Francisco, "The Funduqs of Damascus seen by Frankish Notaries and Merchants" in: Travel in the Middle Ages, edited by M. Sureda, Barcelona, IEMed, 2015, 65-71, 266-270.

246 Ibn Ṭūlūn, Mufākahat al-Khillān, 114, Rabic II 896H, Ibn al-Hanbalī, Durr al-habab fi tarikh a'yan Halab, II, 633. 
highly innovative work, Guy Burak has demonstrated that some seventeenthcentury jurists sought to justify recourse to the Imperial registers as legal proof, even when it was uncorroborated and did not come accompanied with further probative support. ${ }^{247}$ As discussed earlier, a hanafì tradition already existed, which could consider official documents as proof by virtue of their authoritativeness in some exceptional cases, and this practice followed by Mamluk judges is documented in the Ḥaram records. ${ }^{248}$ Moreover, Guy Burak has recently observed that some forms of literary knowledge, such as chronicles, could be certified and used as legal proof in order to validate facts of daily life (which, incidentally, indirectly supports Chamberlains' claims as to the social function of literary works, such as the biographical dictionary). Burak has called this process defterization - the tendency to equate trustworthy information with government-produced records, hence suggesting an Ottoman propensity to "judicialize the written."249 Together with defterization, this research attempts to highlight the parallel - though different-Islamic tendency to "write judicially"; that is, the practice of drafting non-judicial documents in a legally valid form, properly notarized by witnesses. Such artifacts were perceived to be legal valid acts reflecting a truth supported by living, male Muslims, rather than merely recordings of administrative facts.

The oral legal culture of Islam pervaded many aspects of cross-confessional relations, such as diplomatic exchanges, and was indeed a constant source of misunderstanding. Most diplomatic issues were dealt with at the Imperial Council, the Dīvān-ı Hümāyūn, which also functioned as a supreme court of justice. The Venetian Bailo and his delegates attended the Divañn meetings daily; in these sessions, they met the Ottoman dignitaries, the pashas, who acted as representatives of the sultan and would hear and refer to the ruler. As the fulcrum of Ottoman decision-making and governance, the Dìvān hardly suits the distinction between 'political' and purely legal areas of activity, since all decisions were subjected to legal validation-like the taking of testimony or sanctioning by the chief judges. Historians of crossconfessional relations often neglect that it was not only judicial issues that were treated as judicial acts, but also other administrative and diplomatic decisions, and therefore, to be valid, all needed to be "sworn" by witnesses. While government-produced and other authoritative documents were given probative value-most probably the result of an old hanafĩ central-Asian

\footnotetext{
247 Burak, "Evidentiary truth claims".

248 Ayoub, Samy, “"The Sulțān Says”: State Authority in the Late Ḥanafī Tradition”, Islamic Law and Society 233 (2016), 239-278, Johansen, "Formes de langage", 375. 
tradition - conversely many ordinary documents—or at least they were so for the Franks- were for the Muslims mere artifacts that evoked legally binding, oral agreements.

While it is tempting to interpret the new attitudes towards writing and documentation as a sign of modernity, research on Ottoman judicial sources underlines that, if not in practice, traditional notions and ideas about truth and notarization prevailed. As sanctioned by sharīa, the oral nature of truth needed to be taken into account and, particularly during diplomatic and judicial negotiations, Venetian representatives and their Ottoman counterparts invested a great deal of energy into this task. To cite an obvious example, even after they had been written down according to the agreement reached between the two parties, the ahdnames were only considered valid if they were certified by Muslim witnesses in a different time and place. As the Venetians often mention, these documents needed 'to be sworn. ${ }^{250}$ During the last stages of the Veneto-Ottoman negotiations in 1502, the notions and practices involved in the drafting of the decisions provoked a great deal of misunderstanding. For the Ottoman officials, the final document was considered simply to be an aide-mémoire of previous diplomatic talks, rather than as a binding contract. While Venetians stuck to the letter of the document, the final signature was protracted time and again, on the basis that it did not reflect all and every single element agreed upon orally during the negotiation process. Indeed, before proceeding to the final draft, the pashas felt the need to interrogate the dragomans as to whether or not they remembered certain specific conversations that might have arisen during negotiations, on the Venetians' right to use the harbor of Alessio (Lezhë) in Albania. This point was brought up several times at the Dīvān, meaning that omitting parts of a fulfilled agreement was considered to be disrespectful of the truth. ${ }^{251}$ When they were discussed at the Dīvān, the Capitulations needed first to be 'accepted' by the sultan, then 'solemnly sworn,' and finally submitted to the procedure of the 'golden seal'- the tughra or sultan's monogram. The long impasse incurred by this final drafting opened new opportunities to twist the Venetians' arms; arguing that the Capitulations were ready, the Ottomans allegedly demanded additional concessions regarding

250 Venice, Biblioteca Nazionale Marciana (hereinafter BM), Cod. It. VII, 878, 8652, Dispacci Gritti (1502), f.16r., "i capitoli siano sta giurati".

251 BM, Cod. It. VII, 878, 8652, Dispacci Gritti (1502), f. 32r, 37r-v. "un giorno per loro vedermi dicto una cosa, et per el signor de sua bocha propia quella confirmada, et laltro I suo bassa Josarla cum nove pensate, che son cosse da fare I omini vacillare." 
the possession of Cephalonia, under the implicit threat of delaying the final issuance of the treaty. ${ }^{252}$

During the entire negotiation process for the Capitulations, the idea was upheld that it was the sultan who was the ultimate author for the legal act, together with that of guaranteeing oral transmission between himself and the acting negotiators: the capitoli could only be confirmed as valid if written by the sultan's hand or bearing his personal seal (over sigillata cum el annello). ${ }^{253}$ Until the final draft had been solemnly sworn, points could be added, but not after the witnesses had taken the final oath on the document's contents. Even treaties of the utmost importance were, at least in a way, considered to be merely the trace of a verbal agreement concluded with the head of the protected community, memory of which ultimately lived in the heart of trustworthy Muslims. It is generally agreed that the ahdnames were presented as unilateral acts by which the sovereign bestowed concessions upon foreigners, but it also needs to be stressed that the final diplomatic documents were shaped in a totally Muslim context, and were subjected to the sharīa regime of proof. It is perhaps for this reason that the pashas complained of the way Venetians brandished papers under their noses. Over the course of a highly sensitive debt case-the Abdellatif affair - a consul in Alexandria was imprisoned for someone else's debts, in violation of the ahdname. However, the letter of the treaty clashed here with other legitimate proof advanced by the Muslim plaintiff, Abdellatif, who furnished both contracts and witnesses (allegedly forged) attesting that the consul had personally agreed to repay these debts. "Questi toi venetiani spazzano sempre le cose de nostri con un pezzo di carta" "these Venetians of yours bump off every issue on our merchants with a piece of paper") the pasha argued to the Bailo, and later complained that the Franks were "always putting these clauses under my eyes" (mi mettete negli occhi questi nostri capitoli sempre). ${ }^{254}$

The pashas, moreover, seemed to be conscious of the perils of oral agreements and-quite frustratingly for the Bailo-avoided giving their opinion during negotiations. In the Imperial Council, where a vast array of dealings were discussed on a daily basis, the pashas presented themselves publicly as mere intermediaries of the sultan, often refraining from expressing their

252 BM, Cod. It. viI, 878, 8652, Dispacci Gritti (1502), f. 26v, referring to the Ahdname draft, "I capitoli [...] esser acceptadi et solemniter jurati, et de quelli presentada la copia con el sigillo d'oro".

253 BM, Cod. It. VII, 878, 8652, Dispacci Gritti (1502), f.3or.

254 ASVe, Senato, Dispacci degli ambasciatori e residenti, Costantinopoli, 1A, Reg. 1552-57, f. $365,374-6$. 
personal views on the issues discussed. A Bailo complained that "the pashas did not properly answer any of my questions, as they are not used to actually stating their arguments." Here, he is referring to the pashas' tendency, at the Divvān, to limit themselves to a theoretical intermediary role, hence refusing to elaborate "for their duty is to hear and refer, but they said they would make everything known to His Excellency the Sultan, together with the other requests." ${ }^{255}$

Although the Ottoman certification system signaled a giant step towards the generalization of written artifacts as legal evidence, it arose within a context still largely dominated by orality, and more generally by sharīa-based restrictions. If sixteenth-century Ottoman judges and officials preserved more legal documents than their medieval predecessors, early modern Italians did not hide their astonishment at the continued importance of the oral in qadi courts in the Ottoman Empire. In particular, the Venetians remained puzzled by the fact that, during the discussions, no minutes were jotted down by the Dìvān. In principle, when acting as a court of justice the Imperial Council functioned according to the same procedural rules as those in a sharīa court, and it was not easy for foreigners to discern between the discussion of a given commercial issue that was part of a diplomatic, bilateral agenda, and its hearing as a legal case involving Franks. This is why, in Ottoman times, the prevalence of orality in the production of proof provoked both cultural misunderstandings and practical inconveniences. One of the most striking examples of the divergent practices between these two notarial cultures is the lack of transcription of what was discussed during the Dìvān's sessions, something that was common practice for Venice's council meetings. At the Dìvān, most controversial issues were protracted over several days, until a final decision was reached. These decisions were notarized by the Nişancı, present at the hearings, and constitute today the bulk of the mühimme registers, beginning in the 155os. But, again, only verdicts and final decisions were notarized in the daftars or issued as fermans. Court proceedings were not kept in extenso, thus making it impossible to recreate the legal arguments and doctrines that had been mobilized in order to reach these decisions.

The contradictions between the Latin and Ottoman systems crystallized in a much-disputed hearing at the Dīvān reported by Bailo Antonio Barbarigo in September 1552. Lengthy discussions had revolved around a series of debts,

255 "non me resposeno ordinatamente ad cosse alcuna, per non essere loro costume formar parole: et poichè etiam l'officio loro era de udir et referir: ma dixeno che fariano entender a la exma. del signor el tuto insieme con le altre dimande, si del bailo come da I altro marcadanti.", BM, Cod. It. vII, 878, 8652, Dispacci Gritti (1502), f. 22 r. 
incurred by both Ottoman Muslims and a Venetian merchant who had fallen bankrupt. To counter the Bailo's arguments, the pasha brought up an old case concerning a Christian pirate released upon the intervention of a former ambassador, claiming the Venetians should now return the favor by cancelling the debts owed by the Muslim merchants. The pirate had been freed upon a legal decision made by a Muslim judge, and the Bailo claimed that the former must have been proven innocent or have reached an agreement with the plaintiffs, and suggested that the pasha seek out the qadi's decision (the sigilletto) in the archives. The pasha then explained that the trial had not taken place at a local qadi court but had, instead, been transferred to the Imperial Council. It was known, the pasha went on, that in the Dīvān "they do not make notes" and therefore "my word should be given more credit than a qadi's sijill", and I say to you the pirate was found guilty and released only as a concession to the former Bailo. ${ }^{256}$ The pasha clearly highlights here the tension between the oral performance of trusted men, and the value given to notarized deeds. However, he also acknowledges the weight given to the authoritativeness of Muslims and to oral agreements. Indeed, the pirate had been released on the Bailo's word (sopra la parola del Bailo), since - as I will argue in Chapter Four-particular weight was given to it as coming from the head of a protected community. When the Bailo asked to be given a memorandum - "in order to know what to write"- the pasha answered that he should speak personally with the former Bailo and his dragoman, a man called Zanesino. The former Bailo was dead, and due to his age and the time that had passed since the events, his dragoman did not remember; however the pasha insisted that, in order to shed light on the matter, the information should come from this source, in spite of the dragoman's old age. Indeed, the dragomans' capacity to correctly remember facts was a requirement for their appointment, and not only due to the need to memorize vocabulary. Dragomans were required to be present in court for mixed trials, and descriptions of these trials strongly suggest that they took an active role in their clients' defense. This was the case in similar cross-confessional contexts; ${ }^{257}$ in a description of the old Dragoman Franco de Negro the Bailo noted

256 "in divano.. dove che non si fa nota ... la mia parola è creduta piu che sigilletto, et io vi dico che fu provato addosso di lui ogni cosa, le risposi che non contradicevo alla parola della magnificenzia sua, ma che sendo stà rilassato attrovandosi gli adversarii presenti bisognava credere che fusse stà rilassato di volontà loro o per l'innocentia sua o per qualche accordo seguito tra essi.", ASVe, Senato, Dispacci degli ambasciatori e residenti, Costantinopoli, 1 A, Reg. $155^{2-57}$, f.432.

257 Zecevic, Selma, “Translating Ottoman Justice: Ragusan Dragomans As Interpreters of Ottoman Law", Islamic Law and Society 214 (2014), 388-418. 
that he had become old and was losing his "very necessary memory," so that the merchants preferred not to be represented by him before the qadi. 258

In the extensive literature on the-mainly commercial-exchanges with the Ottomans, one comes across complaints time and again about the disregard for the clauses in the ahdnames. Uncertainty often abounded about the duration of the ahdnames, or the very meaning of the word 'truce. ${ }^{.259}$ As we have seen, clarifications on previous discussions that might have had an influence on the drafting of clauses were often required, making it necessary to interview former participants. On their own side, historians often complain about the mysterious absence of originals, while copies circulated freely, and often translations can be found in diplomatic European collections. ${ }^{260}$ As we shall see, crucial clauses were sometimes absent from the letters of the treaties, such as the privilege for Franks to be convicted only on the basis of notarized documents. My contention is that ahdnames belonged to the realm of the judicially written, and were therefore governed by the logic of memory and orality (and this was strictly connected, incidentally, to the necessity for them to be renewed by every new sultan). Yet as the discussion between Antonio Barbarigo and the pasha makes clear, in spite of divergent attitudes towards the written document, even at the epicenter of cross-confessional justice- the Imperial Dìvān-archiving practices were of little significance. The very act of exchanging correspondence with the metropolis was regarded with suspicion: during the talks of 1502 the ambassador's correspondence was often intercepted, and he was sometimes prevented from sending letters to the Doge. This happened because, ten years before, Bayezid II had felt offended by the Bailo's choice to dispatch encrypted messages to Venice. ${ }^{261}$ From the point of view of sharía, diplomacy fitted into the laws of obligation, and therefore followed the logic of orality and trustworthiness governing legal relations. In such an ideal framework of majority-minority contacts, there was no room for official secrets.

Some participants in the debate on archives have argued that it is only by moving away from the state as the principal actor, that a coherent picture of the Mamluk archival mind emerges. In a similar fashion, this research suggests

$25^{8}$ ASVe, Senato, Dispacci degli ambasciatori e residenti, Costantinopoli, 1A, f. $200 v$.

259 "gli avisi al magnifico bassa letti che sua magnifitentia gli hebbe, per che questi nel tradurgli in turco dicono la parola tregua sotto nome di pace conditionata le feci da Zanesino per ogni buon rispetto dichiarire a bocca che detta pace conditionata se intendeva la suspensione d'arme delli 40 giorni che gli haveno gia' l'altra fiale detto.", ASVe, Senato, Dispacci degli ambasciatori e residenti, Costantinopoli, 1 A, f. $377-384$.

260 Steensgaard, Niels, "Consuls and nations in the Levant from 1570 to 1650 ", Scandinavian Economic History Review 15, 1-2 (1967), 13-55, 15.

261 BM, Cod. It. viI, 878, 8652, Dispacci Gritti (1502), f. 34, 79. 
that the traditional distinctions between judiciary and state, or administrative archives are equally problematic. The Mamluk archive appears, at best, to be a very contingent construct: when needed, records and referencing were left in the hands of the men who produced them, and this was never understood as a challenge to Islamic administrative sophistication. Again, I argue that it is the conscious act of preservation, rather than the actors who preserved them, that deserves more attention in future research. As for actual archiving, the Mamluk-Ottoman transition is an important crossing-point that has thus far received remarkably little attention; if there is little to gain in flattening out the differences between the two, the transition from medieval sultanates to Ottoman governance provides us with a fruitful token of comparison for many areas of Islamic history. Notions of governance, such as the using of the Caliphal title, the emergence of a hanafi legal guild, and the ascendency of kanun law are just a few well-known traits of Ottoman rule that made it look different from its medieval predecessors. Similarly, more historical work is needed to scrutinize early medieval Muslims' attitudes towards documents. Allusions by Ibn al-Ṣayrafì, head of the Fatimid Chancery for a forty-year timespan, and by al-Qalqashandì suggest to us that, for the pre-Mamluk periods ranging from early Islamic times to the Abbasid and Fatimid caliphates, a positive attitude towards archiving may have surfaced. ${ }^{262}$ Whenever Caliphate archives actually existed, they succumbed in late medieval times to the sharīa-based regime of proof endorsed by the clerical, legally learned, for which the literary and intellectual spheres of these societies were tailored. This explains why descriptions of notarial practices in late medieval Granada and Jerusalem look surprisingly similar, despite being based on the opposite shores of the Mediterranean.

On the opposite end of the chronology under study, Ottoman governance imposed administrative practices that led to the development of archival devices such as the register, and a long-standing legal reform pushed towards the preservation of judicial collections. There was a logic underpinning the preservation of administrative law; it allowed judges to draw upon a trove of customary rules that could serve as precedent. On the other hand, Ottoman chancery practice departed from precedent and generated its own archive. This contrasts with the tendency of the Mamluks to not preserve copies of the murabba'ät, or minor decrees, which constituted the most common tool of Cairo's governance. ${ }^{263}$ This was particularly true as concerns diplomatic dealings, and more generally relations with the Franks, for which such decrees

262 Sijpesteijn, The Archival Mind In Early Islamic Egypt: Two Arabic Papyri, 164.

263 Popper, Egypt and Syria under the Circassian sultans, 1382-1468 AD; systematic notes to Ibn Taghrî Birdî’s chronicles of Egypt, part II, 24., Hirschler, "From Archive to Archival 
were constantly being issued. ${ }^{264}$ In sum, rethinking the debate on the archival divide and highlighting the different needs, attitudes and logics across time and space makes it possible to draw relevant conclusions on governance and the management of cross-confessional relations. For this reason, in the following chapter I concentrate on excavating a deeper layer in these relations: the realm of doctrines, norms and competent courts. I will be addressing, from a medieval, pre-Ottoman viewpoint, the ways in which cases were adjudicated, and to which judges and courts they were assigned, but also what treaties and normative texts advised for the conclusion and notarization of business deals. More importantly, I look to Venetian notarial evidence for the activity of the Siyāsa courts, run by Mamluk officials, with their characteristic approach to who and what could provide trustworthy testimony.

Practices", 14, notes that, again, examples have survived in the collections of the recipient, such as the Haram papers.

264 They were referred to in the Venetian sources as commandamenti maraba: Pedani, Maria, "Gli ultimi accordi tra i sultani mamelucchi d'Egitto e la repubblica di Venezia", Quaderni di Studi Arabi 12 (1994), 49-64, 52, Horii, Yutaka, "The Venetian Consul and Residents in Egypt under the Ottoman Conquest", Quaderni di Studi Arabi 15 (1997), 121132, 123, Ambasciata straordinaria al sultano d'Egitto (1489-1490), edited by Franco Rossi, Venice: Comitato per la pubblicazione delle fonti relative alla storia di Venezia, 1988, is a hefty corpus of documentation produced during a diplomatic mission to Egypt, where the term is frequently mentioned. See, among others, 218, 221, 232. 